Portland State University

PDXScholar

Spring 4-29-2016

\title{
Sablefish (Anoplopoma fimbria) Scarcity and Zooarchaeological Data Quality in Northwest Coast Archaeological Sites
}

Reno Nims

Portland State University

Follow this and additional works at: https://pdxscholar.library.pdx.edu/open_access_etds

Part of the Archaeological Anthropology Commons

Let us know how access to this document benefits you.

Recommended Citation

Nims, Reno, "Sablefish (Anoplopoma fimbria) Scarcity and Zooarchaeological Data Quality in Northwest Coast Archaeological Sites" (2016). Dissertations and Theses. Paper 2958.

https://doi.org/10.15760/etd.2954

This Thesis is brought to you for free and open access. It has been accepted for inclusion in Dissertations and Theses by an authorized administrator of PDXScholar. Please contact us if we can make this document more accessible: pdxscholar@pdx.edu. 
Sablefish (Anoplopoma fimbria) Scarcity and Zooarchaeological Data Quality in

Northwest Coast Archaeological Sites

by

Reno Nims

A thesis submitted in partial fulfillment of the requirements for the degree of

Master of Science

in

Anthropology

Thesis Committee:

Virginia L. Butler, Chair

Kenneth Ames

Shelby Anderson

Portland State University

2016 


\begin{abstract}
Sablefish (Anoplopoma fimbria) is a scarcely represented species in Northwest Coast archaeology, but its remains are abundant at Tse-whit-zen, a large, Lower Elwha Klallam village in modern Port Angeles, WA that was occupied over the past 2,800 years. Because sablefish flesh has high nutritional value and it can be easily captured from nearshore waters in its juvenile form, sablefish should have been pursued where it was available. Therefore, the scarcity of sablefish in many Northwest Coast archaeological sites could indicate this species was not abundant in past fisheries. However, current zooarchaeological reports do not contain sufficient information on taphonomic histories, sampling, or zooarchaeological methods to determine whether patterns of sablefish scarcity could actually explained by differential destruction of sablefish remains, sample size effects, screen size effects, or misidentification.

In this thesis, I examine how each of these factors may have affected the abundance of sablefish remains in Northwest coast archaeological sites. I evaluate four hypotheses that attribute sablefish representation to zooarchaeological identification methods, screen size, sample size, and post-depositional destruction of fishbone. While I do not explicitly test whether social and ecological factors affect sablefish abundance, sociocultural and environmental variation can be considered likely explanations for the observed patterns of sablefish representation if the other hypotheses are rejected. I test my hypotheses using three scales of archaeological records. First, I reanalyzed six previously analyzed Salish Sea assemblages to assess whether criteria for sablefish identification exist, are valid, and have been applied consistently. Second, I synthesized fishbone data from 35 previously analyzed Northwest Coast assemblages to evaluate the
\end{abstract}


effects of screen size, sample size, and post-depositional destruction on sablefish representation. Finally, I integrate previously unreported fishbone data from the analysis of Tse-whit-zen into the synthesis of previous studies. The Tse-whit-zen materials I report on here represent six discrete time periods in the 1,800-year history of one large area of the site, which encompasses part of a plankhouse, providing a unique opportunity to examine the effects of screening, sample size, and post-depositional destruction at an extremely fine scale. I also use data from the reanalysis of a portion of the Tse-whit-zen fishbone to verify the consistency of sablefish identification for this site.

I reject all four hypotheses and conclude that the uneven distribution of sablefish is likely a true reflection of ecological factors, human decision-making, or both factors. Whether sablefish scarcity is related to distributions of sablefish in past environments, or whether humans chose not to pursue sablefish is not known from the current study. Connecting sablefish capture to specific seasons with body-size regression methods may reveal associations between sablefish acquisition and other seasonal fisheries and activities, and help evaluate whether they conflicted with sablefish procurement in some contexts.

Although zooarchaeological identification and reporting methods do not appear to account for sablefish scarcity, zooarchaeologists need to include more information about their methods so that the validity of inter-assemblage comparisons can be assessed. Zooarchaeologists maximize the value of their contributions to anthropology, biological sciences, and human ecodynamics when they explicitly report the methods they use to identify animal remains. By reporting the methodological and analytic procedures they used in detail, zooarchaeologists enhance the reader's confidence in their conclusions and 
provide future researchers with the information that is required to replicate their results. Which elements were recorded, and the criteria that were used to make taxonomic attributions, fundamentally affect the primary faunal data that researchers use. This study is part of a growing interest among zooarchaeologists in data quality assurance and quality control, which constitute a critical part of every large-scale comparative analysis. 


\section{Dedication}

To Diane Gifford-Gonzalez and Cristie Boone. Thank you for introducing me to archaeology. 


\section{Acknowledgements}

First and foremost, I thank my advisor, Virginia Butler, for her continual support of my research and education, for the active role she plays in the archaeological community, and for helping to make the Tse-whit-zen project a reality. I am also extremely thankful to my committee for the classes they taught at Portland State University (PSU) that helped direct my research topic, and for their comments on my thesis. Thank you to the other principle investigators of the Tse-whit-zen project, whose contributions made my own research possible: Kris Bovy (University of Rhode Island), Sarah Campbell (Western Washington University [WSU]), Mike Etnier (WSU), and Sarah Sterling (PSU). I thank the National Science Foundation (NSF) for funding the Tse-whit-zen project, Washington State Department of Transportation for funding Tsewhit-zen curation fees, and the Burke Museum for curating the Tse-whit-zen materials and facilitating the loan of the fishbone collection. I am especially grateful to the Lower Elwha Klallam Tribe for supporting archaeological research of the Tse-whit-zen collections. I also thank the NSF for funding my graduate research through the Tse-whitzen project grant (Num. 1219468), and the PSU Office of Graduate Studies (OGS) for the Laurels Graduate Award.

I am indebted to everyone whose work on the Tse-whit-zen project has helped to move my own research forward. Katie Mohlenhoff's (2013) pilot research provided identifications and the start of the fishbone database. Kristina Dick's invaluable, ongoing work has helped define site components, catch our mistakes, and integrate the fishbone records into a comprehensive database. Tony Hofkamp and Shoshana Rosenberg also identified Tse-whit-zen fishbone, and Emily Rocha worked tirelessly to record our 
identifications, digitize the information, and catch mistakes. Pat Rennaker's research with cod bones also helped to find errors in the database. Thank you, Tony, for taking the pictures of salmonid vertebral fragments and unidentified fragments that I use in this thesis. No one should ever have to take such high quality photos of unidentifiable crumbs. I would also like to thank Shoshana and Emily for their excellent taste in music and audiobooks.

I am extremely grateful for the support I received for my reanalysis of fishbone collections. Laura Phillips (Burke Museum) provided invaluable assistance by helping me locate and receive permission to study the materials I reanalyzed for my thesis research. Laura also provided immense support during my research at the Burke Museum. I thank the Burke Museum again for granting me access to and curating the West Point, English Camp, and Burton Acres collections. Thank you to the West Point Tribal Oversight Committee for approving my research of the West Point assemblages, to the Puyallup Tribe of Indians for permission to study the Burton Acres assemblage, to the National Park Service (NPS) for permission to study the English Camp assemblages, and to the Bonneville Power Administration (BPA) for curating, and allowing me to study, the Decatur Island assemblage. Tessa Langford (NPS) provided an incredibly prompt response to my research request at a critical moment, and Kevin Cannell (BPA) provided essential help with the loan of Decatur Island materials. Thank you to Stan Gough (Archaeological and Historical Services) for helping me locate the Decatur Island assemblage. I also thank Siri Linz, Jess Milhausen, and Roger Crowley for support and assistance while researching at the Burke Museum. Thank you to Camille Collinson (Parks Canada), Janine Ledford (Makah Cultural and Resource Center), Brad Himour 
(Parks Canada), Trevor Orchard (University of Toronto), and Bill Perry (Parks Canada) for consultation on sites that I ultimately did not study.

In this thesis I verify the work of other researchers who I feel nothing but gratitude for. I thank Rebecca Wigen (Pacific Identifications) for the overwhelming volume and quality of her contributions to zooarchaeological research in the Pacific Northwest. Specifically, I am thankful for her work on the West Point and Decatur Island fishbone assemblages. Thanks, also, to Bob Kopperl (Willamette Cultural Resources Associates) for his work on the Burton Acres and English Camp Op D fishbone assemblages, and Brian Pegg (Kwantlen Polytechnic University) for his work on the English Camp Op A assemblage.

Thank you to Dana Hanselman (National Oceanic and Atmospheric Administration [NOAA]) and Auke Bay Laboratories (Alaska Fisheries Science Center, NOAA) for their ongoing research of juvenile sablefish, and for providing modern sablefish specimens that were crucial to my thesis work. Also, thank you to Dan Kamikawa (NOAA) for supplying Virginia Butler with a collection of sablefish that I used in my research, and James E. West and Dayv C. Lowry (Washington Department of Fish and Wildlife) for consultation about modern sablefish occurrence in the Salish Sea. Many thanks to Connie Cash, who facilitated shipments of dead fish to the Anthropology Department for me without a second thought.

I am very thankful to Iain McKechnie (University of Victoria) for identifying the mysterious fish vertebrae at Tse-whit-zen as sablefish in 2012 during the early months of the project. I am also extremely thankful to the PSU Anthropology faculty for making the Anthropology Department such a welcoming place for students to learn and grow. Thank 
you to William Gardner-O'Kearny for talking to me when I struggled with scatterplots. Thank you to all of the Portland State Anthropology graduate students for your support, friendship, and camaraderie. I thank my family for never questioning my decision to make a career out of studying dead animals. Thank you, Jess Graff, for helping me through thesis-induced life crises.

Finally, to Halley Farwood and Dave Mathews, thank you so much for your friendship. I am truly overwhelmed with gratitude for all of the time we have spent together. 


\section{Contents}

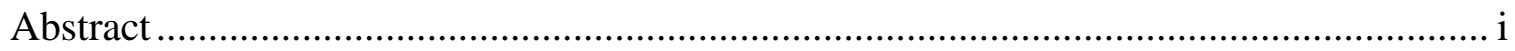

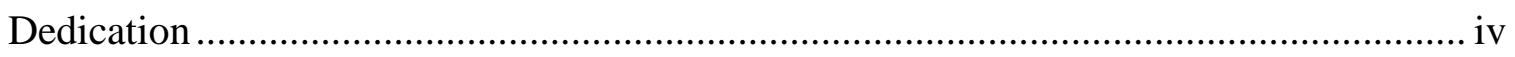

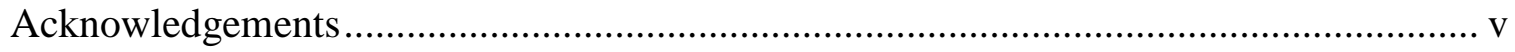

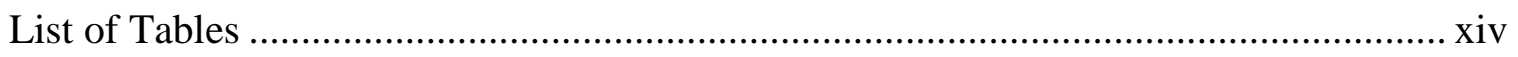

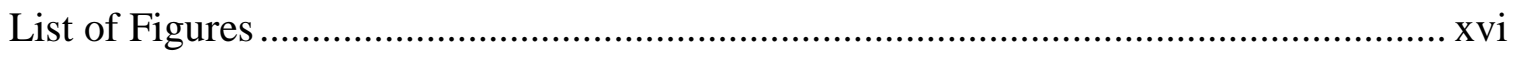

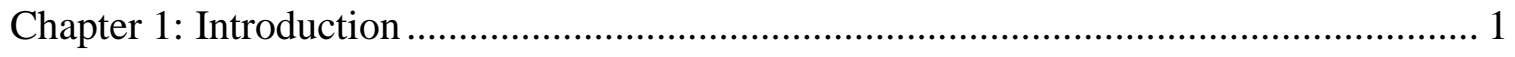

Hypothesis $1\left(\mathrm{H}_{1}\right)$ - Current identification criteria for sablefish are invalid or

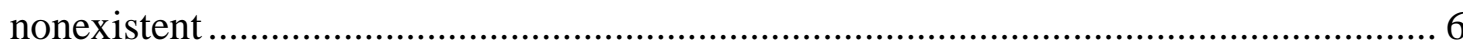

Hypothesis $2\left(\mathrm{H}_{2}\right)$ - Excavators do not use suitably fine screen sizes to recover

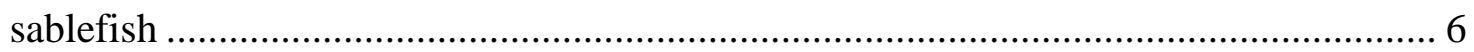

Hypothesis $3\left(\mathrm{H}_{3}\right)$ - Sablefish is scarce because fishbone samples are too small ......... 7

Hypothesis $4\left(\mathrm{H}_{4}\right)$ - Sablefish bones are scarce due to post-depositional destruction ... 7

Hypothesis $5\left(\mathrm{H}_{5}\right)$ - Sablefish representation reflects ancient sablefish biogeography.. 8

Hypothesis $6\left(\mathrm{H}_{6}\right)$ - Humans did not target sablefish........................................ 8

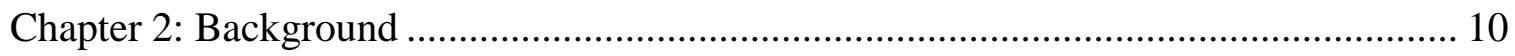

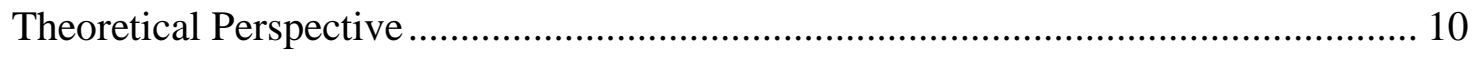

Factors Affecting Sablefish Representation....................................................... 12

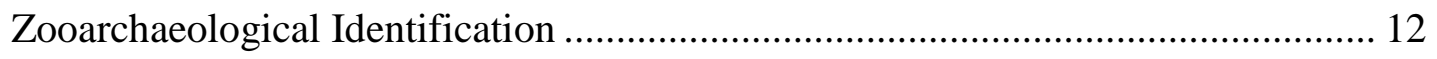

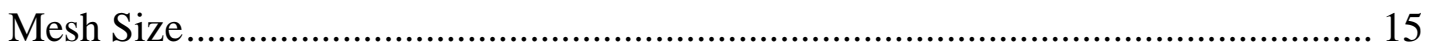

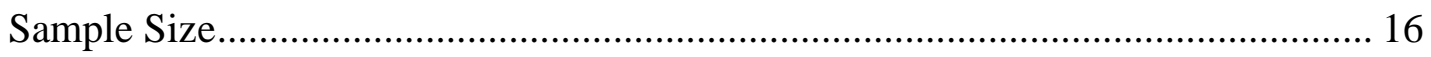




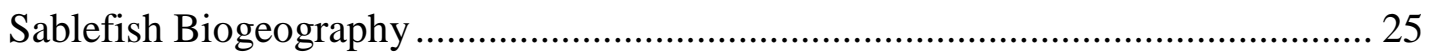

Sablefish in Northwest Coast Archaeological and Ethnographic Contexts ................. 28

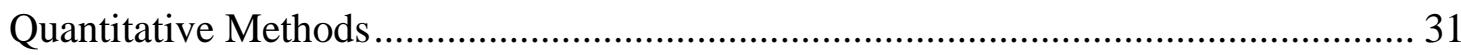

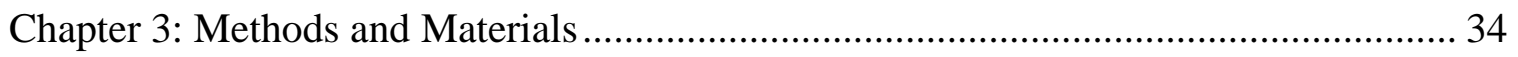

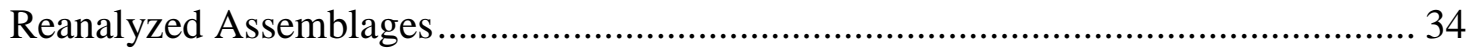

Northwest Coast Fishbone Data Synthesis .................................................... 37

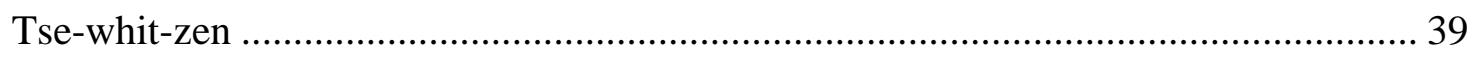

$\mathrm{H}_{1}$ Methods - Current identification criteria for sablefish are invalid or nonexistent.. 43

$\mathrm{H}_{2}$ Methods - Excavators do not use suitably fine screen sizes to recover sablefish ... 47

$\mathrm{H}_{3}$ Methods - Sablefish is scarce because fishbone samples are too small................. 49

$\mathrm{H}_{4}$ Methods - Sablefish bones are scarce due to post-depositional destruction ........... 50

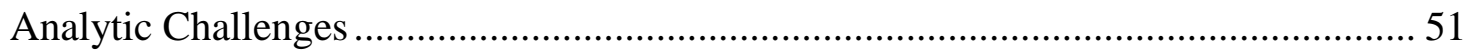

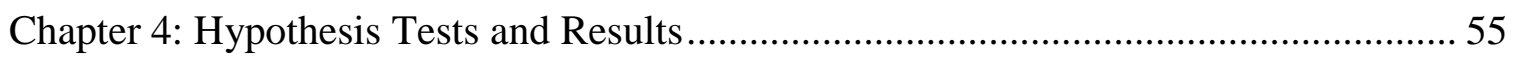

$\mathrm{H}_{1}$ Results - Current identification criteria for sablefish are invalid or nonexistent .... 55

$\mathrm{H}_{2}$ Results - Excavators do not use suitably fine screen sizes to recover sablefish ..... 58

$\mathrm{H}_{3}$ Results - Sablefish is scarce because fishbone samples are too small .................. 62

$\mathrm{H}_{4}$ Results - Sablefish bones are scarce due to post-depositional destruction ............. 66

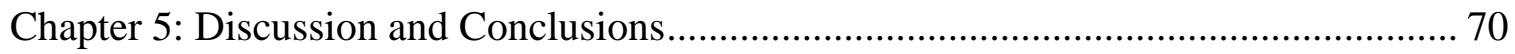

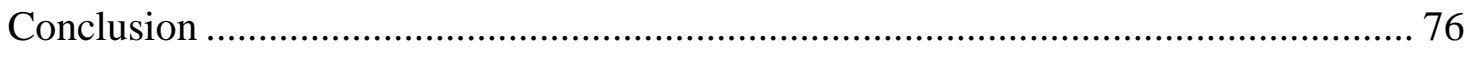




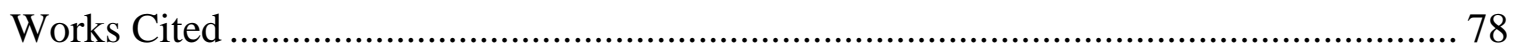

Appendix A: Narrative Descriptions of Synthesized Fishbone Data.................................. 92

Daax Haat Kanadaa - 49SIT244 (Moss 1989) ....................................................... 93

Kilisnoo Picnicground - 49SIT124 (Moss 1989)_...................................................... 93

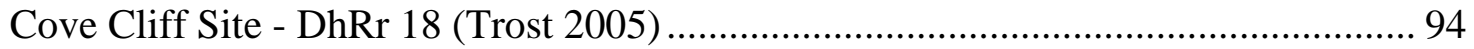

Hoko River Rockshelter - 45CA21 (Wigen 2005) ………………………….......... 96

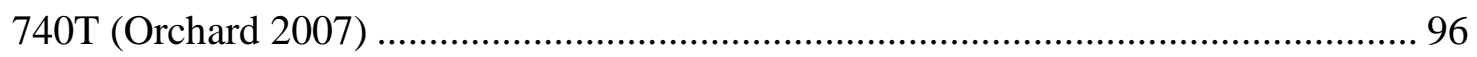

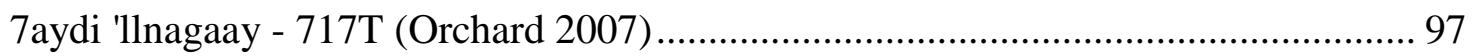

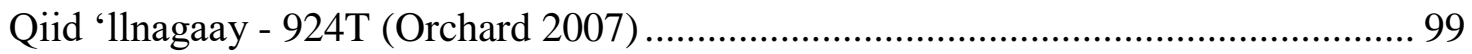

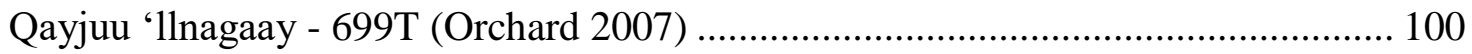

Xuud tsixwaas 'llnagaay - 785T (Orchard 2007) ………........................................ 100

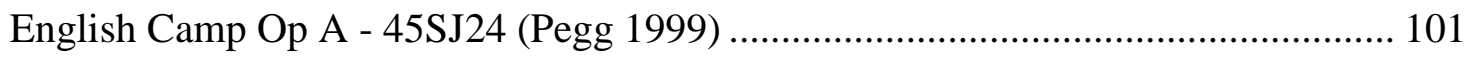

English Camp Op D - 45SJ24 (Kopperl 2011) ………………………………….... 102

Burton Acres - 45KI437 (Kopperl and Butler 2002) ................................................. 103

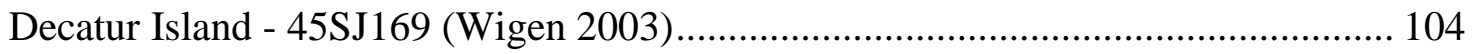

West Point - 45KI428 and 45KI429 (Wigen 1995) ................................................. 106

Bay Street - 45KP115 (Butler and Baker 2002) ………........................................ 108

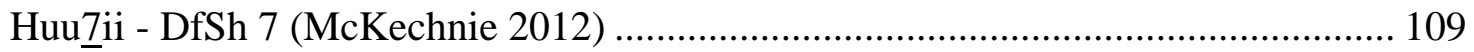

Loon Cave - DiSo 9 (Calvert 1980) …………………........................................ 110

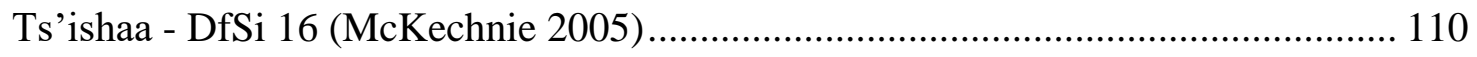


Dionisio Point - DgRv 3 (Ewonus 2011).

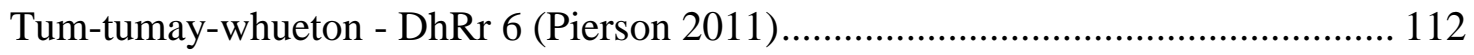

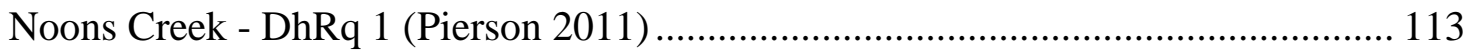

Cama Beach - 45IS2 (Trost 2010) .................................................................... 113

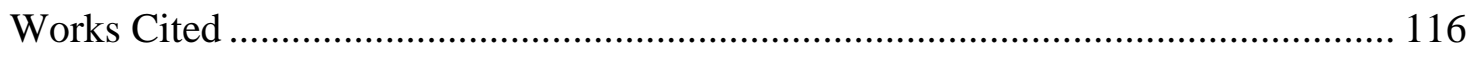

Appendix B: Buckets Selected for Reanalysis from Burton Acres (45KI437), Decatur Island (45IS169), English Camp Op A and Op D (45SJ24), and West Point (45KI428 and 45KI429).

Appendix C: Identification Criteria Used for Reanalysis of Sablefish, Salmonid, Sculpin,

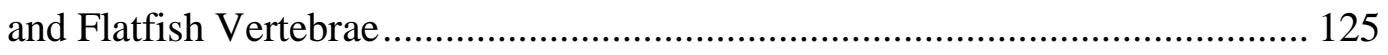

First Vertebra/Vertebra Type 1 .................................................................... 128

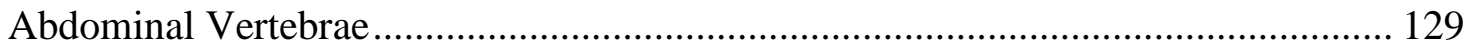

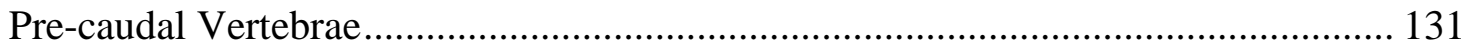

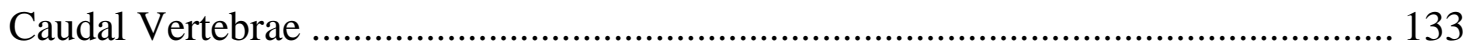

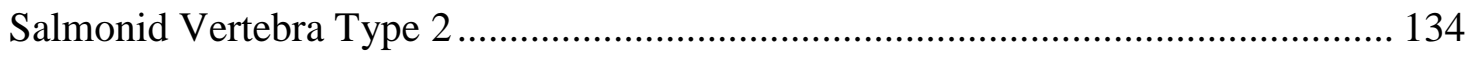

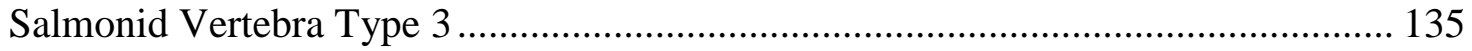

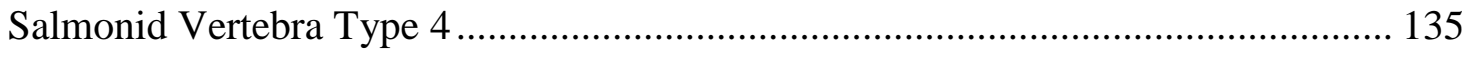

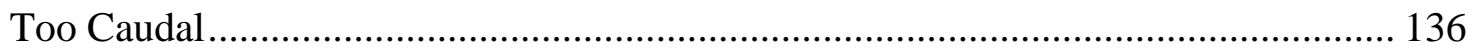

Appendix D: C Bags Selected for Reanalysis from Tse-whit-zen.............................. 138 Appendix E: Supplemental Data File - Primary fish bone data for the original analysis and reanalysis of a portion of the Tse-whit-zen assemblage 140 xii 
Appendix F: Supplemental Data File - Primary fish bone data from the reanalysis of portions of Burton Acres (45KI437), Decatur Island (45IS169), English Camp (45SJ24 Op A and Op D), and West Point (45KI428 and 45KI429) ................. 141 


\section{List of Tables}

Table 1 - Sablefish abundance and quality control measures implemented for Northwest

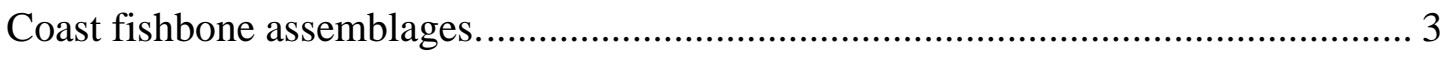

Table 2 - Macronutrient content per 100g of raw Pacific coast fishes............................ 32

Table 3 - Materials used to test hypotheses that may explain sablefish scarcity ............ 34

Table 4 - Previously analyzed fishbone assemblages selected for reanalysis................ 35

Table 5 - Fishbone data available from Northwest Coast archaeological assemblages ... 38

Table 6 - Model 2 x 2 matrix used for Fisher's exact test and to calculate odds ratio..... 49

Table 7 - Analytic challenges for assemblages in the regional fishbone data synthesis.. 52

Table 8 - Rank order comparison of taxonomic abundance at the family level from the original analysis and reanalysis of a sample of the Tse-whit-zen fishbone assemblage

Table 9 - Original and reanalysis counts of vertebral specimens recorded for a $10 \%$

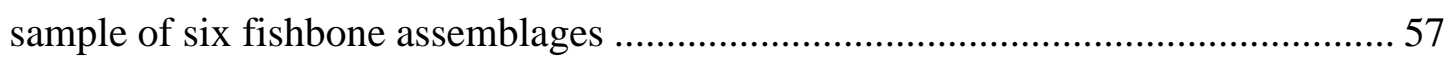

Table 10 - Original and reanalysis vertebrae counts for salmonids and cottids.............. 59

Table 11 - Sablefish representation in individual screen size fractions from Northwest Coast assemblages

Table 12 - Number of assemblages from Tse-whit-zen and regional fishbone data synthesis containing sablefish by minimum screen size used

Table 13 - Sablefish abundance by screen size in buckets with analyzed $<1 / 8$ " bags from Tse-whit-zen 62

Table 14 - Sablefish abundance and sample size for Tse-whit-zen and Northwest Coast assemblages 
Table 15 - Sablefish relative abundance and fragmentation for Tse-whit-zen and

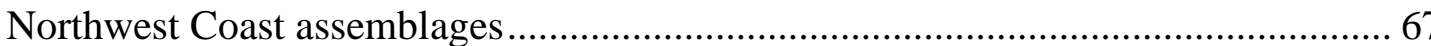




\section{List of Figures}

Figure 1 - Vertebrae from taxa with similarly fenestrated vertebral centrums 14

Figure 2 - Locations of juvenile sablefish tagged and released in southwest Alaska between 1985 and 1991

Figure 3 - Two types of black cod hook recovered from FeUa 3, a fishing gear cache on

Moresby Island in Haida Gwaii ..... 31

Figure 4 - Locations of archaeological sites selected for reanalysis 36

Figure 5 - Locations of sites included in the Northwest Coast fishbone data synthesis .. 39

Figure 6 - Tse-whit-zen site map showing Area A4 42

Figure 7 - Identifiable salmon vertebral fragments and unidentified fish bone specimens 46

Figure 8 - Sablefish abundance and sample size (NISP fishes $)$ by minimum screen size used

Figure 9 - Sablefish abundance and sample size (volume) by minimum screen size used

Figure 10 - Sablefish concentration and fragmentation intensity by minimum screen size

used 68 


\section{Chapter 1: Introduction}

Zooarchaeologists have become increasingly concerned with issues of quality assessment and quality control related to animal bone identification (Allen 2003:338339; Butler and Lyman 1996; Driver 1992 [2011]; Lambrides and Weisler 2016; Lawrence 1973; Gobalet 2001; Wolverton 2013). These concerns are founded in recognition of the fact that the fundamental process of assigning a given bone, shell, or tooth specimen to a taxonomic group entails a complex suite of logical steps. For example, species-level identifications are only possible when analysts limit comparisons to a constrained universe of taxa that are believed to have been present in a specific range of space and time (Driver 2011:27). Taxonomic identification is further complicated by variation in skeletal morphology related to age, sex, and life history. However, few skeletal reference collections capture the complete range of intraspecies variation, or even the full range of animal species known to inhabit a given region. Analysts also use illustrated guides, diagnostic keys, and virtual media while making identifications, which may fill the gaps in a reference collection (Betts et al. 2011:756), but even these are rarely complete and come with their own disadvantages (Driver 2011:23). To resolve these issues, analysts can support their identifications by reporting the taxa that are represented in the reference collections they use and the diagnostic keys they employ (Lambrides and Weisler 2016). Ideally, zooarchaeologists would also report the criteria they use when assigning specimens to particular taxa (Driver 2011:28; Gobalet 2001:385; Lawrence 1973; Wolverton 2013:388). Publishing these criteria raises confidence in taxonomic identification, facilitates validation, and allows researchers to build upon each other's work (Wolverton 2013:392-393). Furthermore, the validity of inter-assemblage 
comparisons is uncertain unless zooarchaeologists report their methodology so that differences in the criteria used (Lawrence 1973:399) and the elements analyzed (Allen 2003:338-339; Lambrides and Weisler 2016) can be identified.

Despite this general concern, Pacific Northwest archaeologists have largely ignored issues of quality assurance and quality control, impeding their ability to address key questions about past human-animal relationships. Most zooarchaeological reports continue to list identified taxa with only limited discussion of the morphological criteria and reference materials that were used to identify animal remains (e.g., Ewonus 2006; McKechnie 2012; Orchard 2007; Trost 2005). These practices may partially account for reports by Moss et al. (2015:5) that some southeast Alaskan assemblages contain specimens identified as Pacific herring (Clupea pallasii) that are actually Pacific tomcod (Microgadus proximus). Such misidentifications have real world consequences when researchers attempt to reconstruct the biogeography of ancient herring populations from zooarchaeological data that has not been subjected to quality control measures (McKechnie et al. 2014).

Data quality issues may also explain the extremely uneven frequencies of sablefish, or black cod (Anoplopoma fimbria), reported in Pacific Northwest coastal archaeological sites. In a pilot study of regional sablefish representation, I found this species is present, but uncommon, at 15 sites along the Northwest Coast (Table 1). Remains of this species are only abundant at Tse-whit-zen (45CA523), a large, Lower Elwha Klallam village in modern Port Angeles, WA. Sablefish occupies nearly every North Pacific habitat over its life history, from the extreme depths of continental slopes to inshore waters, where they can be easily caught by hand-jigging (Echave et al. 2013; 
Table 1 - Sablefish abundance and quality control measures implemented for Northwest Coast fishbone assemblages. ("ID Crit." = reports ID criteria; "Elem. Ana." = reports elements analyzed; "Tax. Univ." = reports taxonomic universe; "Ref. Coll." = reports reference collection; "Elem. Freq." = reports element frequency; "Re-Ana." = reanalyzed; "Verif." = identifications verified)

\begin{tabular}{|c|c|c|c|c|c|c|c|c|c|c|}
\hline Site Name & Site Code & $\begin{array}{c}\text { NISP } \\
\text { Sablefish }\end{array}$ & $\begin{array}{c}\text { ID } \\
\text { Crit. }\end{array}$ & $\begin{array}{c}\text { Elem. } \\
\text { Ana. }\end{array}$ & $\begin{array}{c}\text { Tax. } \\
\text { Univ. }\end{array}$ & $\begin{array}{l}\text { Ref. } \\
\text { Coll. }\end{array}$ & $\begin{array}{l}\text { Elem. } \\
\text { Freq. }\end{array}$ & $\begin{array}{c}\text { Re- } \\
\text { Ana. }\end{array}$ & Verif. & Source \\
\hline Tse-whit-zen - Area A4 & $45 \mathrm{CA} 523$ & 2,778 & $\bar{n} / \mathrm{a}$ & $\mathrm{n} / \mathrm{a}$ & $\mathrm{n} / \mathrm{a}$ & $\mathrm{n} / \mathrm{a}$ & $\mathrm{n} / \mathrm{a}$ & $\mathrm{X}$ & & analysis in progress \\
\hline Hoko River Rockshelter & $45 \mathrm{CA} 21$ & 103 & & $X$ & & $X$ & $X$ & & & Wigen $(2005)$ \\
\hline Huu7ii & DfSh 7 & 65 & & $X$ & & $X$ & & & & McKechnie (2012) \\
\hline Cama Beach & $45 \mathrm{IS} 2$ & 38 & $X$ & $\mathrm{X}$ & & $\mathrm{X}$ & & & & Trost (2010) \\
\hline Ts'ishaa & DfSi $16 \& 17$ & 23 & & $X$ & & $X$ & & & $\mathrm{X}$ & McKechnie (2005) \\
\hline West Point & $45 \mathrm{KI} 428 \& 429$ & 11 & & & & $X$ & $X$ & & & Wigen (1995) \\
\hline Kaidsu & $781 \mathrm{~T}$ & 9 & & & $\mathrm{X}$ & $\mathrm{X}$ & & & & Orchard (2007) \\
\hline Dionisio Point & DgRv 3 & 7 & & & & $X$ & $X$ & & & Ewonus $(2006,2011)$ \\
\hline Xuud tsixwaas 'llnganaay & $785 \mathrm{~T}$ & 4 & & & $\mathrm{X}$ & $\mathrm{X}$ & & & & Orchard (2007) \\
\hline Ma'acoah & DfSi 5 & 1 & & & & $X$ & & & & Monks (2006) \\
\hline Killisnoo Picnicground & 49SIT124 & 0 & & $X$ & $\mathrm{X}$ & $X$ & & & & Moss (1989) \\
\hline Pender Canal & DeRt 1 & 0 & & $\mathrm{X}$ & $\mathrm{X}$ & $\mathrm{X}$ & & & & Hanson (1991) \\
\hline Decatur Island & $45 \mathrm{SJ} 169$ & 0 & & & & $\mathrm{X}$ & $\mathrm{X}$ & & & Wigen (2003) \\
\hline Ozette & $45 \mathrm{CA} 24$ & 0 & $X$ & & & $\mathrm{X}$ & & & & Huelsbeck (1994) \\
\hline Hoko River Wet Site & $45 \mathrm{CA} 213$ & 0 & & & & & & & & Croes (1995) \\
\hline Tum-tumay-whueton & DhRr 6 & 0 & & $\mathrm{X}$ & $\mathrm{X}$ & $\mathrm{X}$ & $\mathrm{X}$ & & & Pierson (2011) \\
\hline Loon Cave & DiSo 9 & 0 & & $X$ & & $X$ & $\mathrm{X}$ & & & Calvert (1980) \\
\hline Cove Cliff Site & DhRr 18 & 0 & & $X$ & $\mathrm{X}$ & $X$ & & & & Trost (2005) \\
\hline Burton Acres & $45 \mathrm{KI} 437$ & 0 & $\mathrm{X}$ & & & $X$ & $\mathrm{X}$ & & & Kopperl and Butler (2002) \\
\hline Duwamish & $45 \mathrm{KI} 23$ & 0 & $X$ & & & $X$ & $X$ & & & Butler (1987) \\
\hline Bay Street & $45 \mathrm{KP} 115$ & 0 & & & & & $X$ & & & Butler and Baker (2002) \\
\hline $740 \mathrm{~T}$ & $740 \mathrm{~T}$ & 0 & & & $\mathrm{X}$ & $X$ & & & & Orchard (2007) \\
\hline $7 a y d i$ 'llnagaay & $717 \mathrm{~T}$ & 0 & & & $\mathrm{X}$ & $X$ & & & & Orchard (2007) \\
\hline Huulaagwaans 'llnagaay & $1134 \mathrm{~T}$ & 0 & & & $X$ & $\mathrm{X}$ & & & & Orchard (2007) \\
\hline Q'iid 'llnagaay & $924 \mathrm{~T}$ & 0 & & & $X$ & $X$ & & & & Orchard (2007) \\
\hline Qayjuи 'llnagaay & $699 \mathrm{~T}$ & 0 & & & $\mathrm{X}$ & $\mathrm{X}$ & & & & Orchard (2007) \\
\hline
\end{tabular}


Moser et al. 1994:157). Ethnographic accounts of fishing practices on the Northwest Coast contain little information on sablefish use, but Blackman's (1990:244) description of Haida people in British Columbia indicates that sablefish was a central fish resource on Haida Gwaii, second only to halibut (Hippoglossus stenolepis) and salmon (Oncorhynchus sp.) in importance. And yet, archaeological sablefish remains are extremely scarce even on the islands of Haida Gwaii.

Unfortunately, we cannot know if sablefish scarcity is actually related to human decision-making or the availability of the species because zooarchaeologists in the Pacific Northwest have not reported the information that is necessary to evaluate this claim. The validity of inter-assemblage comparisons of taxonomic abundance depends on agreement of the criteria used to make taxonomic attributions. Otherwise, there is no reason to assume that two researchers would identify the same number of specimens (Lawrence 1973:398), or even the same taxa (Gobalet 2001) in any assemblage. Even when observers agree on criteria, they may not be able to reproduce the results from an assemblage if they record different elements, exclude different species from analysis, or use different reference collections (Allen 2003:339). Driver (2011), Gobalet (2001), and Wolverton (2013) recommend that zooarchaeologists recognize these potential barriers to inter-assemblage comparisons explicitly and:

1. Report the criteria used to make taxonomic attributions.

2. Report elements recorded during analysis.

3. Report the taxonomic universe considered during analysis.

4. Report the reference materials used to make identifications.

5. Report the frequency of each element identified to each taxon.

6. Verify identifications by re-analyzing a subsample of the assemblage.

7. Have a subsample of identifications verified by external researchers. 
In my pilot study of sablefish representation, I recorded whether researchers followed these recommendations for each assemblage. While Northwest Coast zooarchaeologists routinely report the reference collections used, none of the other recommendations are commonly followed (Table 1). Identification criteria are reported for only four assemblages, and in each of these (Cama Beach, Ozette, Duwamish, and Burton Acres) criteria are reported for only a small subset of the identified taxa.

Without the criteria used to identify fish remains, we cannot know whether sablefish specimens could have been mistaken for other taxa; it is not possible to evaluate the validity of taxonomic identifications from the reports themselves. This is especially concerning in the case of sablefish because the texture of this species' vertebrae is very similar to that of salmon vertebrae. The morphology of sablefish vertebrae also resembles the vertebrae of some sculpins (family Cottidae) and flatfish (order Pleuronectiformes).

In light of these issues, I ask, does the scarcity of sablefish in the archaeological record reflect past distributions of sablefish populations and patterns in human fishing practices? Or is the scarcity of this species a product of poor quality control in archaeological practices? And why are sablefish frequencies so much higher at Tse-whitzen than in other regional assemblages? The primary goals of this thesis are to examine the factors that affect the abundance of sablefish remains in Northwest Coast archaeological sites, and to assess the quality of zooarchaeological data from the region. I propose six working hypotheses (Trigger 2006:514-515) that may explain sablefish scarcity, and attempt to evaluate them individually using non-parametric statistics or by the weight of evidence (Wolverton et al. 2014). Any hypothesis that is supported should 
be considered as a possible explanation for the paucity of sablefish in archaeological sites, and any final explanation is likely to be multi-causal.

Hypothesis $1\left(\mathrm{H}_{1}\right)$ - Current identification criteria for sablefish are invalid or nonexistent If the morphological criteria used by regional zooarchaeologists to identify sablefish are not valid, or if sablefish is not even included in the criteria, then sablefish remains may be systematically misidentified as other taxa. They may also be recorded as 'unidentified' by cautious researchers who do not recognize them. Because there are no criteria reported for this fish, I cannot predict how likely it is that sablefish are misidentified. But the similarities between the vertebrae of sablefish, salmon, sculpins, and flatfish suggest that if sablefish is misidentified, it will be mistaken for one of these taxa.

Hypothesis $2\left(\mathrm{H}_{2}\right)$ - Excavators do not use suitably fine screen sizes to recover sablefish Another factor that may account for the scarcity of sablefish is the screen size used by excavators to recover fishbone assemblages from archaeological deposits. The skeletons of large- and small-bodied fishes are poorly represented in coarse mesh screens (6.4 $\mathrm{mm}$ or greater) if they are recovered at all (Casteel 1972). If sablefish remains are caught disproportionately in fine-mesh screens (3.2 $\mathrm{mm}$ and finer), and if archaeologists do not use these routinely, then sablefish may be underrepresented because archaeologists use screens that are not appropriate for sablefish recovery. 
Hypothesis $3\left(\mathrm{H}_{3}\right)$ - Sablefish is scarce because fishbone samples are too small

The size of a sample that is collected and analyzed from an archaeological deposit necessarily constrains the number of specimens identified for each taxon, and the number of taxa identified (Lyman 2008:141). Zooarchaeologists may analyze a small subsample of recovered assemblages or adopt a limited core and auger sampling strategy so that fishbone from numerous site contexts can be identified in a reasonable amount of time (Cannon 2000). If only a small amount of archaeological material is represented by the fishbone samples that regional archaeologists have analyzed, then sablefish may be absent because the analyzed samples are not representative of the complete assemblages. Sablefish may also be more abundant at Tse-whit-zen than in assemblages recovered through coring because the identified Tse-whit-zen assemblage represents a comparatively large amount of excavated material.

Hypothesis $4\left(\mathrm{H}_{4}\right)$ - Sablefish bones are scarce due to post-depositional destruction Close inspection of the sablefish bones suggests its skeleton is relatively fragile compared to the skeletons of other fishes. Like salmon bones, sablefish bones are fibrous, fenestrated, and lightly built. It is possible that sablefish is scarcely recorded because its skeleton is especially prone to post-depositional destruction and its bones have been degraded beyond recognition or eliminated from archaeological deposits. If postdepositional processes were less intense at Tse-whit-zen than at other sites on the Northwest Coast, sablefish could be better represented at this site because more sablefish bones survived. 
Hypothesis $5\left(\mathrm{H}_{5}\right)$ - Sablefish representation reflects ancient sablefish biogeography

Modern sablefish populations are unevenly distributed on the Northwest Coast.

Juvenile sablefish, for example, are abundant only in specific bays of southwest Alaska.

The size of juvenile populations also varies widely from year to year, with very large year-classes occurring approximately once every seven years (Rutecki and Varosi 1997a). If ancient sablefish populations followed similar life-history patterns, low frequencies of sablefish, or the absence of the species, from archaeological sites could indicate sablefish were not locally available.

Hypothesis $6\left(\mathrm{H}_{6}\right)-$ Humans did not target sablefish

Current archaeological perspectives emphasize the diversity of fish species that Northwest Coast peoples had access to and collected. However, Pacific Northwest economies mobilized large segments of the population to collect several key species such as salmon and herring at specific times of the year. It is possible that human fishers did not target sablefish because its availability conflicted with the harvests of more important or more reliable resources. Sablefish could also be scarce if it required specialized fishing technology that Northwest Coast peoples did not invest in, or if other aspects of resource management prevented sablefish capture.

Even though I pose $\mathrm{H}_{5}$ and $\mathrm{H}_{6}$, my thesis research is focused on testing the first four hypotheses. While I do not explicitly test $\mathrm{H}_{5}$ or $\mathrm{H}_{6}$ in this thesis, sociocultural and environmental variation can be considered likely explanations for the observed patterns of sablefish representation if the other hypotheses are rejected. 
In this thesis I draw on three scales of archaeological records. First, I reanalyzed six previously analyzed Salish Sea assemblages to assess whether criteria for sablefish identification exist, are valid, and have been applied consistently $\left(\mathrm{H}_{1}\right)$. Second, I synthesized fishbone data from 35 previously analyzed Northwest Coast assemblages to evaluate the effects of screen size $\left(\mathrm{H}_{2}\right)$, sample size $\left(\mathrm{H}_{3}\right)$, and post-depositional destruction $\left(\mathrm{H}_{4}\right)$ on sablefish representation. Finally, I integrate previously unreported fishbone data from the analysis of Tse-whit-zen into the synthesis of previous studies. The Tse-whit-zen materials I report on here represent six discrete time periods in the 1,800 -year history of a rigorously sampled plankhouse, providing a unique opportunity to examine the effects of screening, sample size, and post-depositional destruction at an extremely fine scale. I also use data from the reanalysis of a portion of the Tse-whit-zen fishbone to verify the consistency of sablefish identification for this site $\left(\mathrm{H}_{1}\right)$.

This thesis is organized into five chapters. In Chapter 2 I discuss the possible factors that could affect sablefish representation in archaeological sites. I focus on zooarchaeological identification methods, archaeological recovery methods, postdepositional destruction, and aspects of sablefish life history that affect the distribution of populations in the marine environment. I conclude with an overview of the existing evidence for human procurement and consumption of sablefish, and zooarchaeological quantitative units. Chapter 3 describes the reanalyzed assemblages, the fishbone data synthesis, the Tse-whit-zen materials, and the methods that I used to evaluate each hypothesis, as well as the analytic challenges I encountered. In Chapter 4, I present the results of my hypothesis tests. Finally, in Chapter 5, I draw conclusions about past relationships between humans and sablefish. 


\section{Chapter 2: Background}

Theoretical Perspective

My thesis research is situated in the sphere of middle-range theory: the reliable correlations between archaeological data and ethnographic behavior or actualistic test results that archaeologists use to make inferences about the past (Trigger 2006:32-33, 414-415). Much zooarchaeological research has focused on problems of middle-range theory related to explaining site formation processes. The reasoning and methods behind much of this research closely resembles behavioral archaeological theory (GiffordGonzalez 2011:301), which aims to conceptualize processual relationships between human behavior and the material culture that archaeologists study (LaMotta 2012; Schiffer and Skibo 1997; Skibo 2013). However, the connections between zooarchaeological models and behavioral archaeology are rarely made explicit (e.g. Bird and O’Connell 2006:144; Brewer 1992; Broughton and O’Connell 1999:160-161; Gifford-Gonzalez 2011:299; Marciniak 1999).

In particular, zooarchaeological models of assemblage formation bear a close resemblance to behavioral chains or châine opératoire. While a châine opératoire describes the individual steps of artifact production, a behavioral chain describes an artifact's life history from the procurement of raw material, to artifact production and use, to discard and possible reuse or recycling (Skibo 2013:8). Models of animal bone assemblage formation, or taphonomic histories, make similar step-by-step summaries of human-animal relationships. However, taphonomic histories differ from behavioral chains because they also describe the history of changes that occur to animal remains after they are deposited (e.g. Lyman 2008:24; Reitz and Wing 1999:110-112). 
Reitz and Wing (1999) and Lyman (2008) model taphonomic histories as a series of events that add information to an assemblage and decrease the integrity of the information that it contained before. They state that all animal bone assemblages begin as animals on a landscape as part of a life assemblage (Lyman 2008:23; Reitz and Wing 1999:110). This population is structured in part by human behavior (Reitz et al. 2009:23). A portion of the life assemblage enters the death assemblage when humans cull animals for food or secondary products like skin, sinew, or bone (Reitz and Wing 1999:112). Death assemblage accumulation can also be passive (Lyman 2008:23), as it is when rodents burrow into middens. The animal remains that accumulate together become a deposited assemblage, which is subsequently modified by dispersal and decomposition from biotic and abiotic agents (Lyman 2008:24; Reitz and Wing 1999:112). The deposited assemblage is further modified during archaeological recovery by excavators' decisions regarding where to excavate, how to recover samples, and the size of the sample they collect. Whatever portion of the deposited assemblage that is recovered and identified to a taxon is the identified assemblage, at which point the information it represents is affected by how analysts choose to record and report data.

The six hypotheses I pose to explain sablefish scarcity are related to specific elements of the taphonomic history model. $\mathrm{H}_{1}$ suggests sablefish scarcity is related to data loss during identification and reporting. Sablefish scarcity could also be a result of sampling the deposited assemblage during archaeological recovery $\left(\mathrm{H}_{2}\right)$ and zooarchaeological analysis $\left(\mathrm{H}_{3}\right)$. Post-depositional modification and destruction of sablefish bone in deposited assemblages is another factor that I consider $\left(\mathrm{H}_{4}\right)$. My last two hypotheses explain sablefish scarcity at the level of the death assemblage $\left(\mathrm{H}_{6}\right)$ and 
the life assemblage $\left(\mathrm{H}_{5}\right)$. However, entire taphonomic histories are flattened to create zooarchaeological records. Information about biogeophysical conditions, sociocultural patterns, local ecological patterns, political and economic conditions, and integrated social-ecological systems are always recorded in animal bone assemblages, even though they cannot be isolated from one another or the effects of site formation processes and zooarchaeological methods (Reitz et al. 2009:20). I make no attempt to isolate these variables. Instead, I recognize that the actual explanation for sablefish scarcity is likely multi-causal, and evaluate each hypothesis separately to evaluate which specific factors could play important roles.

Factors Affecting Sablefish Representation Zooarchaeological Identification

The skeletal elements of many vertebrates share morphological similarities with multiple taxa (Driver 2011:23). When researchers fail to publish identification criteria used to distinguish taxa, the validity of their claims and inter-site comparisons are suspect (Lambrides and Weisler 2016; Lawrence 1973). Without knowing the criteria that analysts use to attribute specimens to a taxon, the reader has no basis for placing confidence in the identifications (Wolverton 2013:393). Ideally, such criteria are explicitly defined in writing before analysis begins (Driver 2011:27; Gobalet 2001:385; Wolverton 2013:388), making it a relatively simple matter to include decision rules with a zooarchaeological report, or publish the criteria separately and cite them later (Lawrence 1973). Zooarchaeologists can also evaluate how consistently they apply identification criteria by reanalyzing portions of identified assemblages to estimate how 
often they agree with their own taxonomic attributions (Butler and Schroeder 1998:967; Preston in Driver 2011:37; Wolverton 2013:390).

Regardless, the potential for misidentification of fish remains is real. Gobalet's 2001 study highlights this issue, and shows that four professional zooarchaeologists recorded vastly different taxa in the same Central California coast assemblage. While one analyst identified 18 species in the assemblage, the other researchers identified half that number at most, and one researcher only identified four species (Gobalet 2001:378). Neither extreme of this spectrum is ideal. The analyst who identified 18 species is likely overconfident in their ability to differentiate taxa, while the latter did not maximize the data potential of the assemblage (Gobalet 2001:380).

As I discussed in Chapter 1, Pacific Northwest zooarchaeologists have not considered the ways that different identification criteria might affect the results of fishbone identification. Salmon (genus Oncorhynchus) vertebral fragments are sometimes identified solely by the fenestrated surface of the vertebral centrum (Butler 2004:320; Ewonus 2011:86; Pegg 1999:97). However, sablefish are also characterized by this texture. Further confusion is introduced by the abdominal vertebrae of staghorn sculpin (Leptocottus armatus) and some flatfishes (Pleuronectiformes), which also have fenestrated centra and bear a superficial similarity to the vertebrae of sablefish (Figure 1). Analysts who use reference collections that lack sablefish, or who are unaware of the characteristics that distinguish these species, may misidentify sablefish vertebral fragments as another taxon. If this problem is widespread, it may contribute to overestimations of salmonid's importance in regional diets that Pacific Northwest archaeologists continue to challenge (Campbell and Butler 2010; Monks 1987; Moss and 


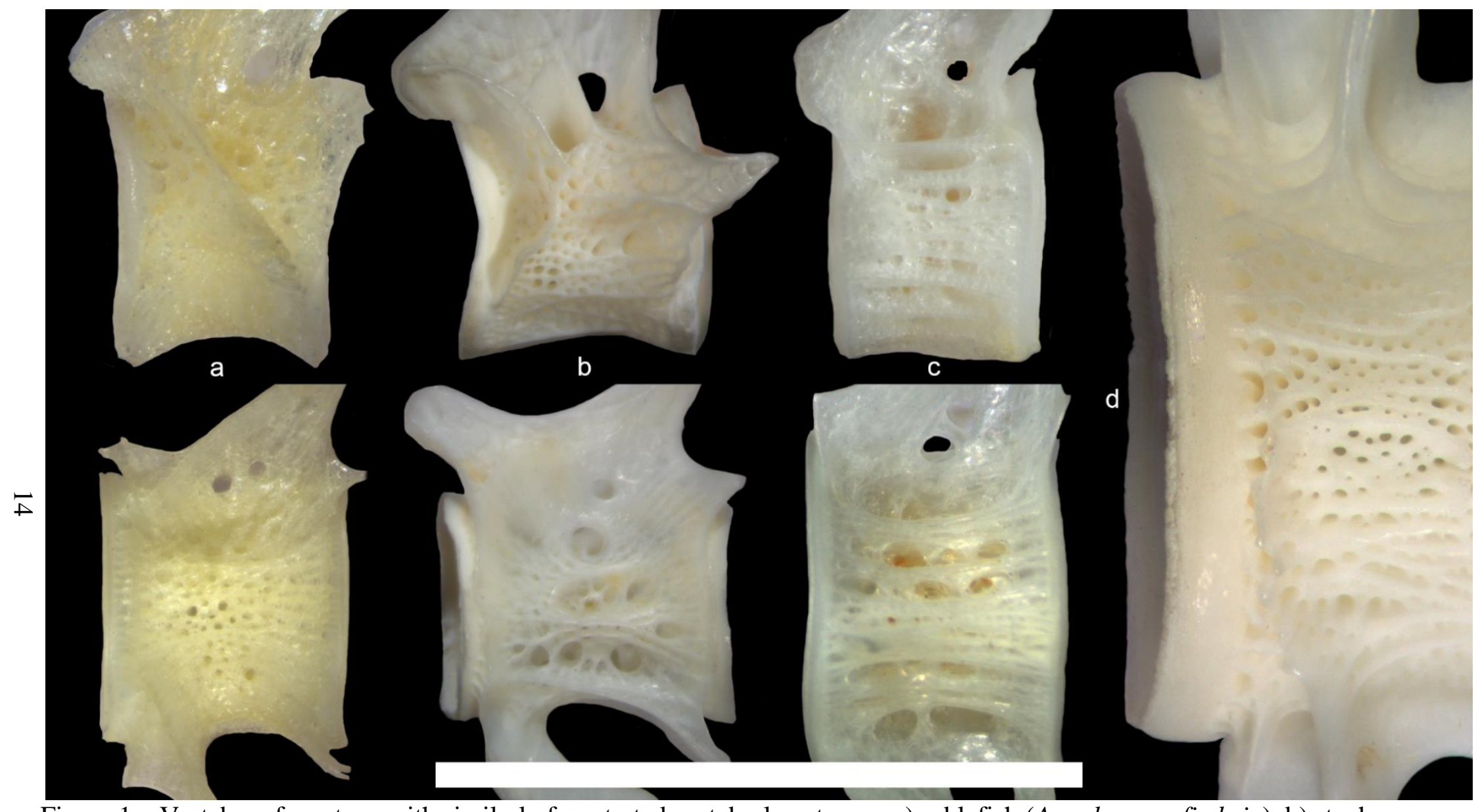

Figure 1 - Vertebrae from taxa with similarly fenestrated vertebral centrums: a) sablefish (Anoplopoma fimbria), b) staghorn sculpin (Leptocottus armatus), c) rex sculpin (Glyptocephalus zachirus), d) salmon (Oncorhynchus kisutch). Scale bar is $10 \mathrm{~mm}$ long. Top row: abdominal vertebrae. Bottom row: caudal vertebrae. Salmon vertebra is a Type 3. 
Cannon 2011). When reports lack information on the reference skeletons or identification criteria that are used, we cannot know if sablefish remains are scarce because of misidentification, or for other reasons.

Mesh Size

The uneven abundance of sablefish remains could also be related to the mesh sizes used to sample archaeological deposits during excavation. Casteel (1972) established the dramatic effects of mesh size on the recovery of fish remains, but archaeologists have been concerned about this problem to varying degrees. Only recently in the Pacific Northwest have samples from archaeological excavations been wetscreened in $6.4 \mathrm{~mm}\left(1 / 4\right.$ ") and $3.2 \mathrm{~mm}\left(1 / 8^{\prime \prime}\right)$ hardware cloth to separate sediment from animal remains and small pieces of lithic debitage, increasing the visibility of these materials and simplifying their collection (Lyman 2008:152; Moss and Cannon 2011:7). Occasionally, bulk samples are also recovered and screened through $2 \mathrm{~mm}$ or $1 \mathrm{~mm}$ mesh to collect a representative portion of small fish remains (Butler 1996:705; McKechnie 2005). Large quantities of bone from fish, small-bodied tetrapods, and fragmentary specimens are often lost with loose sediment through coarse-mesh screens. Therefore, the accurate interpretation and comparison of animal bone - and especially fish assemblages depends on the consistent use of fine-mesh screens (3.2 mm or smaller) at all sites under consideration (Casteel 1972; Gordon 1993; James 1997; Lyman 2008:155; Partlow 2006). Because sablefish may have been captured predominately as small-bodied juveniles (see Sablefish Ecology below), I expect their bones are predominantly 
recovered in $3.2 \mathrm{~mm}$ or finer mesh, and the scarcity of this species could be a result of heavy reliance on coarse-mesh screens (6.4 mm or greater).

\section{Sample Size}

Assemblages of animal remains are necessarily influenced by the amount of archaeological deposits that are recovered and analyzed. Increasing the size of an assemblage increases the number of specimens and taxa represented, and may change the relative abundance of each taxon (Lyman 2008:142). Small identified assemblages will likely include only the most abundant taxa from the deposited assemblage. To obtain samples that include all of the taxa represented in an assemblage, archaeologists can continue analyzing new subsamples until no new taxa are observed. This is called sampling-to-redundancy (Lepofsky and Lertzman 2005; Lyman 2008:144-145). Sampling-to-redundancy has seen some recent use in the Pacific Northwest (e.g. Lyman and Ames 2004; Rosenberg 2015), and it has also been applied retroactively to determine whether an identified assemblage is representative (McKechnie 2005, 2012; Smethurst 2014). However, the method remains underutilized (Lyman 2008:149) and the representativeness of most Northwest Coast assemblages has not been explicitly assessed. Because many of the Northwest Coast site samples in Table 1 may not be representative of deposited assemblages, differences in the frequencies of fishbone and the observed taxa could be a product of differences in sample size (Lepofsky and Lertzman 2005:181).

To control for differences in sample size when assemblages may not be representative of the deposited assemblages, zooarchaeologists have adopted rarefaction methods from botany and ecology that reduce samples to a standard size. Rarefaction 
uses random sampling to determine the number of species that would be identified in an assemblage if a smaller sample had been analyzed (Lepofsky and Lertzman 2005; Lyman 2008:160; Lyman and Ames 2007:1987; Woo et al. 2015). This method can also be used to make valid comparisons of taxonomic abundance across assemblages of different sizes (Lyman 2008:Figure 4.9, 167). Rarefaction assumes that all samples in the rarefied assemblage come from the same population, and requires careful definition of the target population in complex sites with multiple components to ensure that only homogenous samples are rarefied (Lyman 2008:163).

If the goal is simply to decide whether or not comparisons between assemblages with different sample sizes are valid, zooarchaeologists can use the "regression approach" to measure the effects of sample size on any target variable. In this method, the target variable and sample size from statistically independent assemblages are plotted on a graph and used to calculate the best-fit regression line (Lyman 2008:165; Lyman and Ames 2007:1988). Some archaeologists have used regression models to predict artifact diversity in assemblages from known sample sizes. If the predicted and observed measures are highly correlated, it is assumed that sample size explains the observed artifact diversity (Byrd 1997:54-55; Rhode 1988). This application of the regression approach has been heavily criticized, in part because it assumes that artifact diversity is the same for assemblages used to generate the model and the assemblage being studied (Baxter 2001; Lepofsky and Lertzman 2005:177). The method that Lyman and Ames (2007; Lyman 2008:165) describe differs from Rhode's (1988) regression approach because it uses regression to test whether sample size and artifact diversity (or any other variable) are correlated for a set of assemblages. If the correlation coefficient of the 
regression model is statistically significant, then differences in sample size must be considered as a possible explanation for the behavior of the target variable (Lyman 2008:165; Lyman and Ames 2007:1988).

\section{Taphonomy}

Taphonomic processes can create patterns in assemblages of animal remains. It is therefore essential to determine whether differences between assemblages reflect variation in the life or death assemblages, and not taphonomic effects on the deposited assemblage. Taphonomy is the study of human and non-human processes that affect organic materials and the biases these processes introduce to the archaeological and paleontological records (Gifford 1981:388; Lyman 1994:1, 2008:264). Taphonomic processes acting on animal bone assemblages change bone element frequencies by causing differential destruction and selective transport of certain elements or bodysegments (Gifford 1981:400). Taphonomic research may reveal information about human behaviors that are responsible for the attrition or modification of animal bone, including prey selection and procurement, selective body-part transport, butchery and culinary processing, and disposal practices. Taphonomic research also seeks to identify patterns in bone assemblages that are not caused by humans to understand how animal remains, and our quantitative measures of them, are changed by taphonomic processes (Lyman 1994:5-7; Lam et al. 2003). Such processes must be identified so that differences between bone assemblages caused by non-human actors are not mistaken for differences in human behavior or the environmental context in which humans lived. 
Much taphonomic research has been devoted to identifying the ways that depositional environments determine bone preservation. Hedges et al. (1995) and Nielsen-Marsh and Hedges (2000) present a range of diagenetic parameters that allow for direct comparisons of chemical and structural bone deterioration for large mammals. The results of their Northwestern European studies privilege the role of hydrological environments in preservation, and suggest bones are better preserved when water content of soils remains constant (Nielsen-Marsh and Hedges 2000:1146-1147). Experiments designed to test the generalization that acidic soils degrade bone and alkaline soils enhance preservation show that patterns of fishbone destruction are actually very similar at both extremes of the pH scale (Collins 2010; Lubinski 1996). Nicholson (1996:523, 529) argues that burial depth, the presence of coverings, the state of the corpse, post burial temperature and rainfall, and soil texture are more important predictors of bone preservation than $\mathrm{pH}$ or intrinsic properties of bones themselves. In a similar line of reasoning, Jans et al. (2004) argue that bacterial degradation of bone depends on the perimortem state of an animal carcass. For example, butchered animal parts are often not deposited with endogenous bacterial colonies from the intestinal tract that attack bone during early decomposition, but putrefaction of complete animal bodies causes biological degradation of bone (Jans et al. 2004:91-92). Exceptional preservation may also be observed in bones recovered from organic refuse in anaerobic conditions (i.e. compost) where humic factors generated by plant decomposition infiltrate bone, inhibiting collagenases and bacterial attack (Jans et al. 2004:91; Nicholson 1998).

Directly measuring the effects of taphonomic processes and environmental conditions on an assemblage of animal remains is difficult. The body of research cited 
above assesses bone condition at archaeological sites using porosimetry, histology (Hedges et al. 1995; Jans et al. 2004; Nielsen-Marsh and Hedges 2000), protein content, carbonate content, crystallinity (Hedges et al. 1995; Nielsen-Marsh and Hedges 2000), skeletal completeness scores, and subjective bone condition scores (Nicholson 1996, 1998). While such sophisticated approaches may have great value, they have not been applied in the Northwest Coast, and other methods are required to assess whether taphonomic processes could be responsible for sablefish scarcity.

Other taphonomic researchers have developed methods to test whether the properties of bones that may affect preservation (i.e. density, size, and shape) actually explain the observed patterns of species and body-part representation. One widely used method for estimating the intensity of taphonomic effects on a bone assemblage compares the frequencies of skeletal elements to the density of those elements. Taphonomists using this method assume that differential destruction of skeletal parts is explained by differences in bone density. Elements, and portions of elements, with a given bulk density $\left(\mathrm{g} / \mathrm{cm}^{3}\right)$ are expected to have a greater probability of surviving mechanical and chemical forces than less dense elements because they are more dense (Butler and Chatters 1994; Lam et al. 2003; Lyman 1985; Smith et al. 2011). If the frequencies of various taxa or body-parts are positively correlated with density values from modern examples of the archaeological specimens, then density-mediated destruction must be considered when explaining the formation of an archaeofaunal assemblage.

Bone density values for a given species are often not uniform across its entire skeleton, potentially creating confusion if body-part representation is used to assess 
butchery practices. For example, low frequencies of salmonid head parts relative to the post-cranial skeleton in Pacific Northwest sites have been interpreted as evidence of fish storage (Butler and Chatters 1994:413). But Butler and Chatters (1994) demonstrate that most salmonid cranial elements have lower bone density than salmonid vertebrae. Patterns of density-mediated destruction and butchery, therefore, cannot be distinguished for salmon in assemblages containing fewer cranial elements than vertebrae.

Interpreting body-part representation for other taxa is not necessarily subject to the same problems. Because density in Pacific cod (Gadus macrocephalus) skeletons is consistent across all body-parts (Smith et al. 2011:49), and high-density elements are present in each body segment of sucker (Catostomus macrocheilus) skeletons (Stevenson and Butler 2015:182), density-mediated destruction cannot explain differential body-part representation for these species. Other patterns of density are also possible, and these studies suggest the role of density-mediated destruction must be carefully considered for each taxon.

Bone density also varies between taxa, creating issues for interpretations of human prey choice based on the relative abundance of bone specimens from different species. For instance, comparisons of Pacific cod and salmon skeletons indicate that salmonid elements are less dense and less likely to survive deposition and recovery than cod (Partlow 2006:72; Smith et al. 2011:49). Before drawing conclusions about the importance of different taxa in human procurement strategies, archaeologists must consider the effects of differential destruction on taxonomic representation.

Sablefish skeletons are likely highly vulnerable to post-depositional destruction. While bulk density values have not been measured for sablefish skeletal elements, 
sablefish bones appear to be lightly built and extremely fragile. After I cooked and macerated several sablefish, I noticed that their vertebrae can be easily crushed between two fingers. Though anecdotal, this observation suggests that sablefish bone density is even lower than both salmon and cod bone density, and that sablefish remains are more prone to post-depositional destruction than other fish taxa. Unfortunately, we lack bone density values for many Northwest Coast fish taxa, preventing robust assessments of the effects of density-mediated destruction on fishbone assemblages. Furthermore, this approach would not be effective even if density values were available because researchers have failed to report element frequencies in the Pacific Northwest (Moss 2011:161). As I discuss above, density-mediated destruction is taxon and element specific. Without a complete range of density values and element representation data, density-mediated destruction on fishbone assemblages cannot be assessed.

Specimen fragmentation rates provide an alternative measure of post-depositional destruction in an assemblage. Lyman (2008:250-251) identifies two dimensions of fragmentation, the extent of fragmentation and the intensity of fragmentation. The extent of fragmentation can be estimated by the proportion of complete specimens to the total number of specimens identified for a taxon (Lyman 2008:250; Wolverton 2002:89; Wolverton et al. 2008:15). Measuring the extent of fragmentation with this method requires that a measurement of completeness was recorded for the specimens in an assemblage. However, completeness measures are typically not documented for fish, and they are actually very difficult to measure reliably. Instead, many zooarchaeologists prefer to measure fragmentation using fragmentation intensity. 
Fragmentation intensity is the average size, or number, of fragments that an element has been broken into. A widely used measure of fragmentation intensity is the ratio of the number of identified specimens (NISP) to the minimum number of elements (MNE) represented for a single taxon, excluding complete specimens (Lyman 2008:251252; Wolverton 2002:89; Wolverton et al. 2008:15). Zooarchaeologists count MNE to avoid overestimating the contribution of a single bone that has broken into multiple specimens. MNE is calculated by counting the number of specimens from the same anatomical element that have the same morphological landmarks. Fragments that could have derived from the same bone are excluded (Lyman 2008:218-222). Calculating NISP:MNE uses this information to estimate how many specimens each whole bone has been broken into. Relatively high NISP:MNE ratios indicate that each bone was broken into more pieces, while ratios approaching 1:1 imply each specimen is nearly complete. However, the relationship between NISP and the level of fragmentation is not linear. As fragmentation increases and elements are broken into smaller and smaller pieces, fewer of those specimens are likely to be identifiable (Cannon 2013; Lyman 2008:253-254; Marshall and Pilgram 1993). Therefore, a NISP:MNE ratio approaching 1:1 may indicate specimens are relatively complete, or that they are fragmented beyond recognition, rendering this measurement of fragmentation intensity potentially useless. This problem of equifinality can be solved by comparing NISP:MNE ratios with other measures of fragmentation such as completeness (Wolverton et al. 2008:16) or NSP:NISP (see below) (Wolverton 2002:91).

In an experiment designed to empirically evaluate the validity of fragmentation measurements as estimates of fragmentation intensity, Cannon (2013) found that average 
specimen size is the most useful measure for comparing fragmentation intensity of specific elements of a particular taxon. Specimen size decreases linearly with increasing fragmentation, and it can be used to compare fragmentation for specific taxa (Cannon 2013:414-416). This method is highly biased by the size of the complete elements represented in an assemblage. For example, comparing an assemblage of whole deer scapulae to an assemblage of whole deer phalanges on the basis of average size would incorrectly suggest fragmentation is greater in the latter (Cannon 2013:418). Because of this issue, average specimen size should only be compared for adult mammals and birds on an element-by-element basis. The method would not be a valid measure of fragmentation for animals that grow indeterminately, such as fishes, reptiles, amphibians, or invertebrates.

One final measure of fragmentation that can be easily calculated from commonly reported zooarchaeological data was also validated by Cannon's (2013) experiment. The ratio of the number of specimens (NSP) to the NISP in an assemblage measures the intensity of fragmentation. This method assumes that as taphonomic processes break bones into a greater number of ever smaller fragments, the specimens in an assemblage will become less identifiable. NSP:NISP has also been referred to as the identifiability rate, with the implication that identifiability is controlled by fragmentation (Grayson 1991:487; Nagaoka 2005:1336). Cannon (2013:411) shows the relationship between NSP and NISP is linear, unlike similar calculations for the minimum number of individuals (MNI) or MNE. Larger NSP:NISP ratios indicate greater fragmentation, with few identifiable specimens relative to the number of specimens in the assemblage (Wolverton et al. 2008:16). Ratios of NSP:NISP approaching 1:1 always suggest that all specimens 
are complete enough to enable identification. The NSP:NISP ratio cannot be calculated for individual taxa because NSP by definition incorporates unidentified specimens that cannot be attributed to any taxon, and it cannot be used to characterize differential handling practices (Cannon 2013:411). Baker (Baker 2009:41) also cautions that NSP:NISP may be greatly influenced by recovery methods, analyst experience, and the analyst's research objectives. Nevertheless, it is an effective and widely used tool for quantifying fragmentation intensity in assemblages (Medina 2014:124) and evaluating whether post-depositional destruction explains differences between them (Grayson 1991; Nagaoka 2002, 2005; O’Brien 2015; Otaola 2012; Wolverton et al. 2008).

Because sablefish bones are very fragile, and their representation could be greatly influenced by post-depositional destruction, I use NSP:NISP ratios to compare the intensity of fragmentation among sites and determine whether sablefish scarcity is explained by differences in taphonomic histories (Cannon 2013:418). I recognize that this measure over-simplifies extremely complex site histories, and that documenting the specific processes that structure assemblages remains an important undertaking. However, the NSP:NISP ratio is the most effective measure of fragmentation that can actually be calculated from the data that is currently reported for most sites.

\section{Sablefish Biogeography}

Current biogeographical information on sablefish life history suggests Northwest Coast peoples most likely caught these fish as juveniles. Sablefish is a demersal species that can live over 100 years and grow to over a meter in length. Though mature individuals may come very close to shore on occasion (Love 2011:282), adults normally 
occupy the deep waters of continental slopes between 200-1,400 m depth where they are only accessible through long-line fishing methods (Head et al. 2014; Pearson and Shaw 2004:127; Rutecki and Varosi 1997b:45). Young of the year measuring 20-40 cm, on the other hand, are common in bays and inlets along the Pacific coast and are efficiently caught by hand-jigging in waters 20-60 m deep (Echave et al. 2013:29; King et al. 2000:64; Rutecki and Varosi 1997a:48-50). While humans may have pursued adult sablefish with deep sea fishing techniques in the past (Hobler 1978:46), juveniles should have provided an attractive, low-cost resource in many places along the Pacific coastline.

One important aspect of juvenile sablefish ecology that should be considered when evaluating ancient use patterns is the geographic variation in their distribution and abundance. During a seven year survey of juvenile sablefish populations in a region of southeast Alaska, Rutecki and Varosi (1997b) found that juvenile sablefish were present in 11 bays and inlets (Figure 2), but were only captured in substantial numbers at St. John Baptist Bay. Why sablefish prefer this bay remains unknown (Rutecki and Varosi 1997a:48), but Coutré (2014:71) suggests juveniles might prefer bays with freshwater input where salmon offal is available. Alternatively, sablefish may be entrained in St. John Baptist Bay as larvae.

Even this relatively dependable source of sablefish showed large variations in catch size between seasons and survey years. In fact, many of the sablefish captured at sites other than St. John Baptist Bay were associated with the strong year class of 1985, when juveniles were extremely abundant throughout the region (Rutecki and Varosi 1997b:Table 1, 126). Though poorly understood, these periodic "strong year class" 


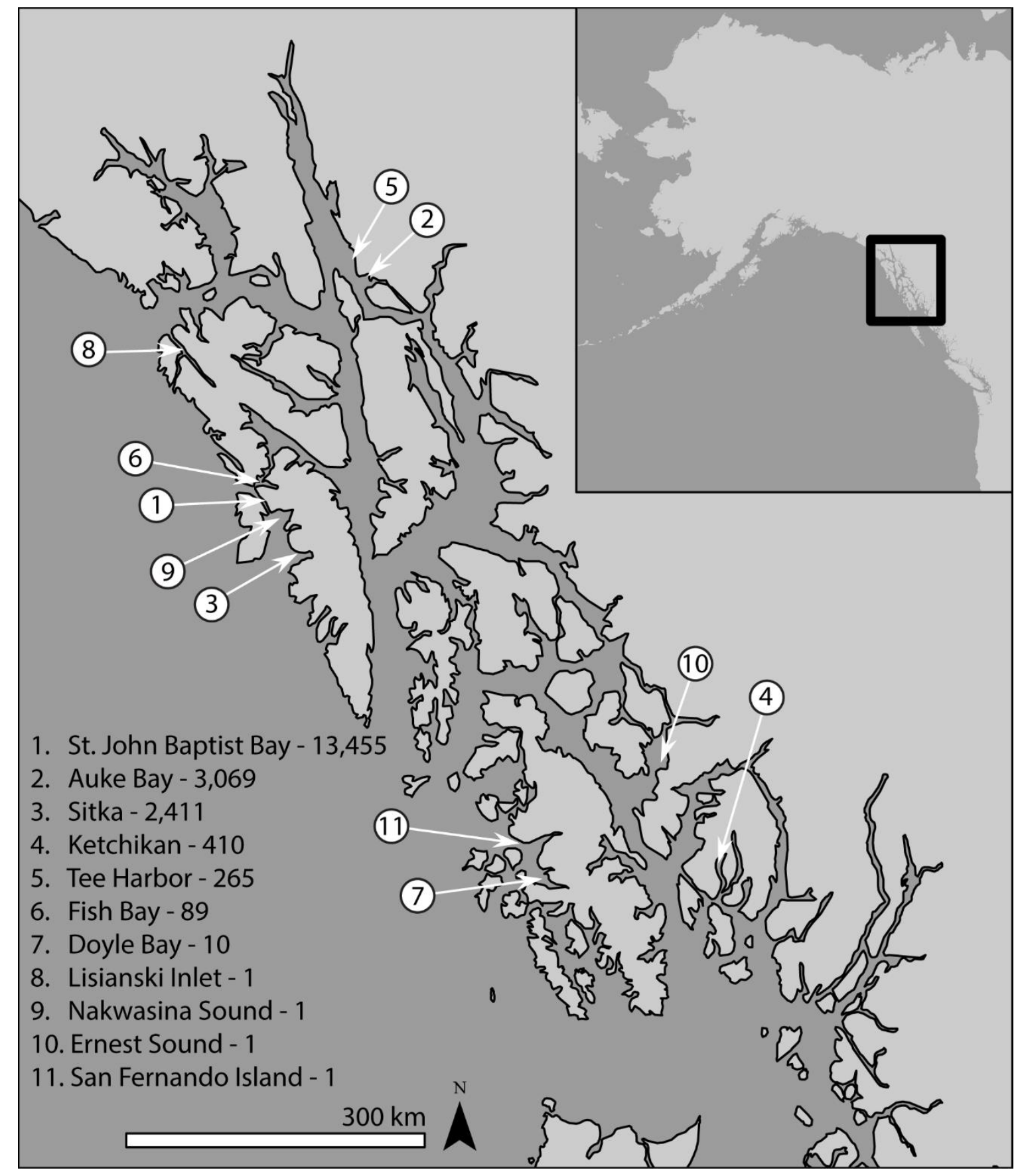

Figure 2 - Locations of juvenile sablefish tagged and released in southwest Alaska between 1985 and 1991 (adapted from Rutecki and Varosi 1997b:124). The total numbers of tagged sablefish are given next to the names of catch locations. 
increases in juvenile populations correlate with favorable environmental conditions such as warmer sea surface temperatures (Sogard 2011), and have resulted in enormous sablefish catches from piers elsewhere on the Pacific coast (Cox 1948; McFarlane et al. 1997:28). If year class strength was as irregular in the past as it is today, uneven sablefish representation at archaeological sites may simply reflect this unpredictable, temporal variation in the abundance and availability of juvenile sablefish. Archaeological records may contribute to modern understandings of sablefish distributions by providing historical perspectives on nearshore ecosystems that juveniles prefer.

Sablefish in Northwest Coast Archaeological and Ethnographic Contexts

A synthesis of Northwest Coast ethnographic records in the Smithsonian Institution's Handbook of North American Indians, Volume 7 (Suttles 1990b) contains little information on sablefish use. In 10 of the 19 cultural and linguistic groups for which subsistence information is reported, only five fish taxa are cited as important food sources (salmon, eulachon, herring, halibut, and sturgeon; Linnaean taxonomy was not reported for these fishes). Numerous zooarchaeological analyses of ancient and contact-era fishbone assemblages confirm these taxa played key roles in past foodways, but the studies also demonstrate that many other taxa were at least as important in terms of culture and nutrition (Campbell and Butler 2010; Ewonus 2011; McKechnie et al. 2014; McMillan and St. Claire 2005; Moss 2010; Moss and Cannon 2011). Hanson (1991:385387, 395-396) argues these biases (including 'salmonopia': the overestimation of salmon's importance in regional diets [Monks 1987:119]) might be related to the participation of many Northwest Coast peoples in commercial salmon and halibut 
fisheries following Euro-American colonization. Because many of the interviews cited in Suttles (1990b) were conducted after 50 to 70 years of commercial fishing, the emphasis on salmon in ethnographies should not be surprising (Hanson 1991:387). These sources can help to develop expectations about patterns of past fish use, but they are not reliable evidence of pre-commercial fish use in and of themselves.

Despite these limitations, sablefish do appear in at least two accounts of Northwest Coast fishing practices. Blackman (1990:224) notes that 'sable-fish' was a preferred food source among the Haida. Further evidence for sablefish use among the Haida was recorded in a story told by John Sky to John R. Swanton (1905:210-226). In Supernatural-Being-Who-Went-Naked, the titular character pays an extended visit to the west coast of Haida Gwaii and is asked, "Does the black cod stick you here?" (Swanton 1905:220, 222). Swanton (1905:225) notes this expression refers to the exclusive availability of 'black cod' on the west coast of the islands, and that visitors to the region had such high regard for the fish they would delay their departure. Arima and Dewhirst (1990:397) mention that groups of Nootka and Nitinaht speakers on the west coast of Vancouver Island also captured 'sablefish' and 'lingcod' with lures and harpoons or dipnets from canoes. In addition, Suttles (1990a) argues that ethnographers often included several species of marine fishes - including sablefish - in the non-taxonomic group of 'cod' or 'codfishes.' Therefore, reference to 'cod' procurement by the Eyak (DeLaguna 1990a:190), the Tlingit (DeLaguna 1990b:211), the Makah (Renker and Gunther 1990:423-424), and Coastal Salish peoples (Hajda 1990:505-507; Kennedy and Bouchard 1990:444-445; Suttles and Lane 1990:456-457) indirectly suggest that sablefish may have been widely captured on the Northwest Coast. 
Unfortunately, understanding the roles of sablefish in Northwest Coast archaeological contexts is difficult because researchers have referred to fishes by colloquial or common names without citing Linnaean taxonomy. This practice has created confusion where one name refers to multiple species, or multiple names exist for the same species. For example, confusion created by the reliance on common names is evident in the disagreement over the fishes that bentwood fishhooks were used to capture. According to Swan's observations from 1873, Haida Gwaii fishers caught 75 'black cod' at a time with a hundred specialized bentwood fishhooks attached "to a single line, which acts like a trawl" (in Hobler 1978:44). Archaeological examples of the eponymous black cod hook (Figure 3) have been identified at a contact-era cache on Moresby Island, Haida Gwaii (Hobler 1978), and similar hooks were recorded at 13 so called "wet sites" (waterlogged cultural deposits with preserved perishable materials) along the Northwest Coast (Croes 2003). Croes (2003:54) argues these slender, bentwood fishhooks appeared in the Salish Sea as early as 4,000 B.P. at Glenrose Cannery (DgRr 6) and were commonly used throughout the region until their contact-era disappearance. However, neither Swan nor Hobler (1978) cite the scientific name for their 'black cod,' and it is unclear whether they actually refer to Anoplopoma fimbria. In a description of the black cod hook, Stewart (1977:23) uses the name 'black cod' to identify the black rockfish (Sebastes melanops), but Croes (1988) argues these bentwood hooks may have been used to capture 'Pacific cod' from the family Gadidae, or 'codfishes' in general. Until these disagreements are resolved, black cod hooks should not be used as evidence of procurement for any particular taxa. 

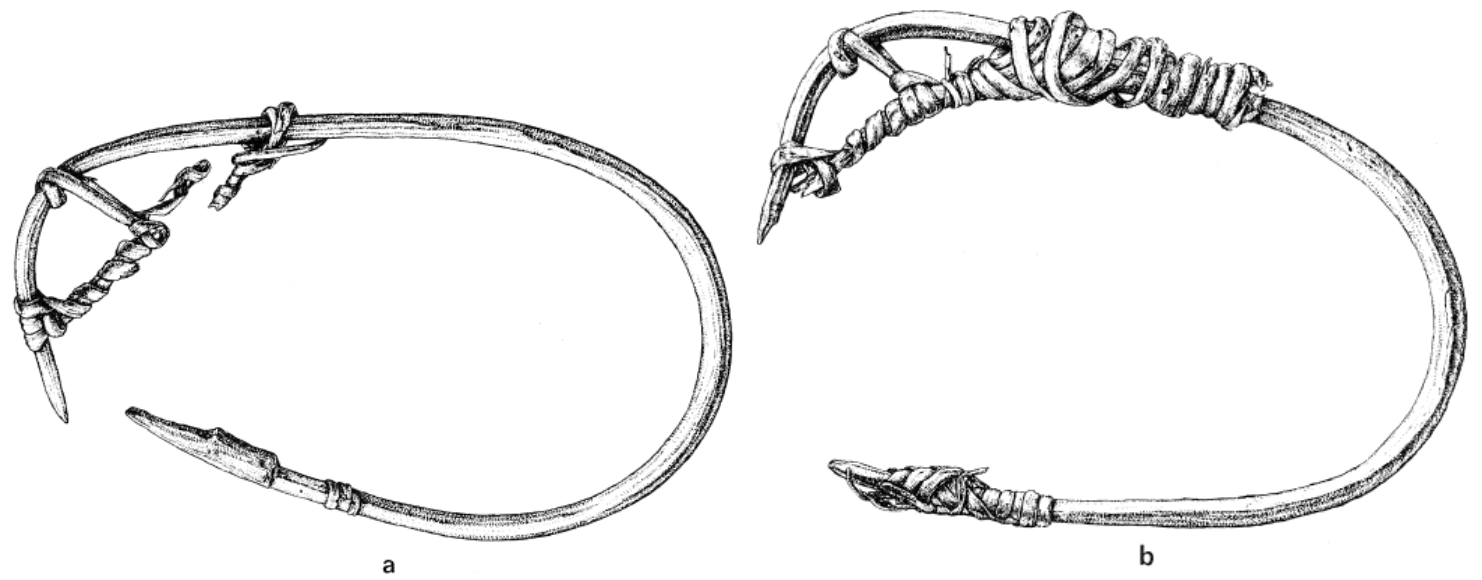

Figure 3 - Two types of black cod hook recovered from FeUa 3, a fishing gear cache on Moresby Island in Haida Gwaii: a) one-piece, b) composite (from Hobler 1978:41).

Another line of evidence that anthropologists and archaeologists sometimes use to explore foodways is the nutritional content of plants and animals that make up a given diet (e.g. Speth and Spielmann 1983). Nutritional assessments of high protein diets typical of the Northwest Coast often emphasize the importance of dietary fat for avoiding protein poisoning (Cannon 1995). Of the 15 Pacific fish types for which the U.S. Department of Agriculture (2014) reports nutritional statistics, sablefish have the highest dietary fat content and are tied for the highest number of calories (Table 2). Based on the high nutritional quality of sablefish and the presence of juveniles in nearshore waters, I expect that Northwest Coast peoples would have chosen to procure sablefish when they were available.

Quantitative Methods

In this thesis, I quantify fishbone abundance using the number of identified specimens (NISP), which is simply a tally of the specimens attributed to a taxonomic 
Table 2 - Macronutrient content per 100g of raw Pacific coast fishes (U.S. Department of Agriculture 2014).

\begin{tabular}{|c|c|c|c|c|c|c|c|c|c|}
\hline Common Name & Taxon & $\begin{array}{c}\text { Energy } \\
\text { (kcal) }\end{array}$ & $\begin{array}{l}\text { Protein } \\
\text { (g) }\end{array}$ & $\mathbf{n}$ & $\begin{array}{c}\text { Std. } \\
\text { Error }\end{array}$ & $\begin{array}{c}\text { Fat } \\
\text { (g) }\end{array}$ & $\mathbf{n}$ & $\begin{array}{c}\text { Std. } \\
\text { Error }\end{array}$ & $\begin{array}{l}\text { Date of } \\
\text { Study }\end{array}$ \\
\hline Sablefish & Anoplopoma fimbria & 195 & 13.41 & 169 & 0.089 & 15.30 & 178 & 0.314 & 1987 \\
\hline Pacific Herring & Clupea pallasii & 195 & 16.39 & 70 & 0.133 & 13.88 & 128 & 0.475 & 1987 \\
\hline Chinook Salmon & Oncorhynchus tshawytscha & 179 & 19.93 & 9 & 0.420 & 10.43 & 12 & 1.478 & 2003 \\
\hline Mackerel; Pacific and Jack & Scombridae & 158 & 20.07 & 11 & - & 7.89 & 126 & 0.865 & 1987 \\
\hline Coho Salmon & Oncorhynchus kisutch & 146 & 21.62 & 178 & 0.044 & 5.93 & 219 & 0.161 & 1987 \\
\hline Sockeye Salmon & Oncorhynchus nerka & 142 & 21.31 & 4 & 0.560 & 5.61 & 4 & 1.695 & 2010 \\
\hline European Anchovy* & Engraulis encrasicolus & 131 & 20.35 & 1 & - & 4.84 & 26 & 0.318 & 1987 \\
\hline Shark; mixed species & Elasmobranchii & 130 & 20.98 & 16 & 0.256 & 4.51 & 52 & - & 1987 \\
\hline Pink Salmon & Oncorhynchus gorbuscha & 127 & 20.50 & 3 & 0.702 & 4.40 & 3 & 2.091 & 2010 \\
\hline Chum Salmon & Oncorhynchus keta & 120 & 20.14 & 8 & 1.222 & 3.77 & 13 & 0.650 & 1987 \\
\hline Sturgeon; mixed species & Acipenseridae & 105 & 16.14 & 2 & - & 4.04 & 7 & - & 1987 \\
\hline Rainbow Smelt & Osmerus mordax & 97 & 17.63 & 47 & 0.222 & 2.42 & 52 & 0.107 & 1987 \\
\hline Atlantic and Pacific Halibut & Hippoglossus sp. & 91 & 18.56 & 10 & 0.378 & 1.33 & 10 & 0.308 & 2010 \\
\hline Perch; mixed species & Perciformes & 91 & 19.39 & 39 & 0.172 & 0.92 & 24 & 0.049 & 1987 \\
\hline Rockfish; mixed species & Scorpaenidae & 90 & 18.36 & 4 & 0.344 & 1.34 & 4 & 0.467 & 2010 \\
\hline Lingcod & Ophiodon elongatus & 85 & 17.66 & 173 & 0.078 & 1.06 & 16 & 0.143 & 1987 \\
\hline Flounder and Sole species & Pleuronectiformes & 70 & 12.41 & 4 & 1.031 & 1.93 & 4 & 0.431 & 2010 \\
\hline Pacific Cod & Gadus macrocephalus & 69 & 15.27 & 11 & 0.823 & 0.41 & 11 & 0.037 & 2010 \\
\hline
\end{tabular}

*proxy for Pacific Anchovy (Engraulis mordax) 
order or finer in an archaeological assemblage (Lyman 2008:26). Some researchers prefer to measure taxonomic abundance using the minimum number of individuals (MNI), which is most often defined as being equal to "the most commonly occurring kind of skeletal specimen of a taxon in a collection" (Lyman 2008:39). NISP and MNI both have fundamental flaws, but both are also valid, ordinal scale measures of taxonomic abundance that provide redundant information (Lyman 2008:Chapter 2). I use NISP because it is the most commonly reported unit of fishbone abundance in the Northwest Coast.

Because NISP is an ordinal scale measure at best (Lyman 2008), only nonparametric statistical tests that compare data at the ordinal or nominal scale are appropriate for zooarchaeological analysis (Wolverton et al. 2014). In this thesis, I use Spearman's rank order correlation coefficient $\left(r_{s}\right)$ to test whether the rank order taxonomic abundance of sablefish is correlated with several independent variables. Spearman's correlation test evaluates the hypothesis that two ordinal scale variables are correlated in $n$ independent cases. If the correlation coefficient is significant at the specified level of confidence ( $\alpha=0.05$ throughout this thesis), there is enough evidence to reject the null hypothesis that the two variables are not correlated. I calculate Spearman's correlation coefficient and the significance of the result ( $p$ ) using IBM SPSS version 23 . Because it is possible to achieve a statistically significant correlation when no meaningful relationship exists, I report the effect size $\left(r_{s}^{2}\right)$ to show what percentage of the variability in the target variable (sablefish abundance) is explained by a given independent variable (Wolverton et al. 2014). 


\section{Chapter 3: Methods and Materials}

My thesis research draws on three scales of archaeological records: reanalyzed fishbone assemblages from the Salish Sea, synthesized fishbone data from previously analyzed Northwest Coast assemblages, and previously unreported fishbone data from six time periods of the Tse-whit-zen assemblage. Here, I describe each set of materials that I incorporated into my hypothesis tests, and how I applied these materials to test each hypothesis (Table 3). I conclude the chapter with a discussion of the analytic challenges that I encountered during my analysis of the synthesized fishbone data.

Reanalyzed Assemblages

I reanalyzed six previously analyzed assemblages to evaluate the possibility that sablefish have been systematically misidentified $\left(\mathrm{H}_{1}\right)$ : Burton Acres, Decatur Island (45KI429 only), English Camp (Op A and Op D), and West Point (both sites) (Table 4;

Figure 4). My selection was expedient, and largely determined by my ability to access the collections. However, I also selected these assemblages because they represent large samples of archaeological fishbone, and, in the case of West Point, because sablefish is reported as present. Because I am primarily concerned that sablefish vertebrae may have

Table 3 - Materials used to test hypotheses that may explain sablefish scarcity.

\begin{tabular}{lccc}
\hline \multicolumn{1}{c}{ Hypothesis } & $\begin{array}{c}\text { Reanalyzed } \\
\text { Assemblages }\end{array}$ & $\begin{array}{c}\text { Northwest } \\
\text { Coast Synthesis }\end{array}$ & $\begin{array}{c}\text { Tse-whit-zen } \\
\text { Fishbone Data }\end{array}$ \\
\hline $\mathrm{H}_{1}-$ ID Criteria & $\mathrm{X}$ & & $\mathrm{X}$ \\
$\mathrm{H}_{2}-$ Mesh Size & & $\mathrm{X}$ & $\mathrm{X}$ \\
$\mathrm{H}_{3}-$ Sample Size & & $\mathrm{X}$ & $\mathrm{X}$ \\
$\mathrm{H}_{4}-$ Post-Depositional Destruction & & $\mathrm{X}$ & $\mathrm{X}$ \\
\hline
\end{tabular}


Table 4 - Previously analyzed fishbone assemblages selected for reanalysis.

\begin{tabular}{|c|c|c|c|c|c|}
\hline Site Name & Site Number & Analyst & Screen Sizes Used & Owner & Curator \\
\hline Decatur Island & 45SJ169 & Wigen (2003) & $1 / 4 ", 1 / 16 "$ & $\begin{array}{l}\text { Bonneville Power } \\
\text { Administration }\end{array}$ & $\begin{array}{c}\text { Bonneville Power } \\
\text { Administration, Portland, OR }\end{array}$ \\
\hline Burton Acres & $45 \mathrm{KI} 437$ & Kopperl and Butler (2002) & 1", 1/2", 1/4", 1/8" & Puyallup Tribe of Indians & Burke Museum, Seattle, WA \\
\hline English Camp Op A & $45 \mathrm{SJ} 24$ & Pegg (1999) & $1 ", 1 / 2 ", 1 / 4 ", 1 / 8 "$ & National Park Service & Burke Museum, Seattle, WA \\
\hline English Camp Op D & $45 \mathrm{SJ} 24$ & Kopperl (2011) & $1 ", 1 / 2 ", 1 / 4 ", 1 / 8 "$ & National Park Service & Burke Museum, Seattle, WA \\
\hline West Point & $45 \mathrm{KI} 428$ & Wigen (1995) & $1 ", 1 / 2 ", 1 / 4 ", 1 / 8 "$ & $\begin{array}{l}\text { West Point Tribal } \\
\text { Oversight Committee }\end{array}$ & Burke Museum, Seattle, WA \\
\hline West Point & $45 \mathrm{KI} 429$ & Wigen (1995) & $1 ", 1 / 2 ", 1 / 4 ", 1 / 8 "$ & $\begin{array}{c}\text { West Point Tribal } \\
\text { Oversight Committee }\end{array}$ & Burke Museum, Seattle, WA \\
\hline
\end{tabular}

u 


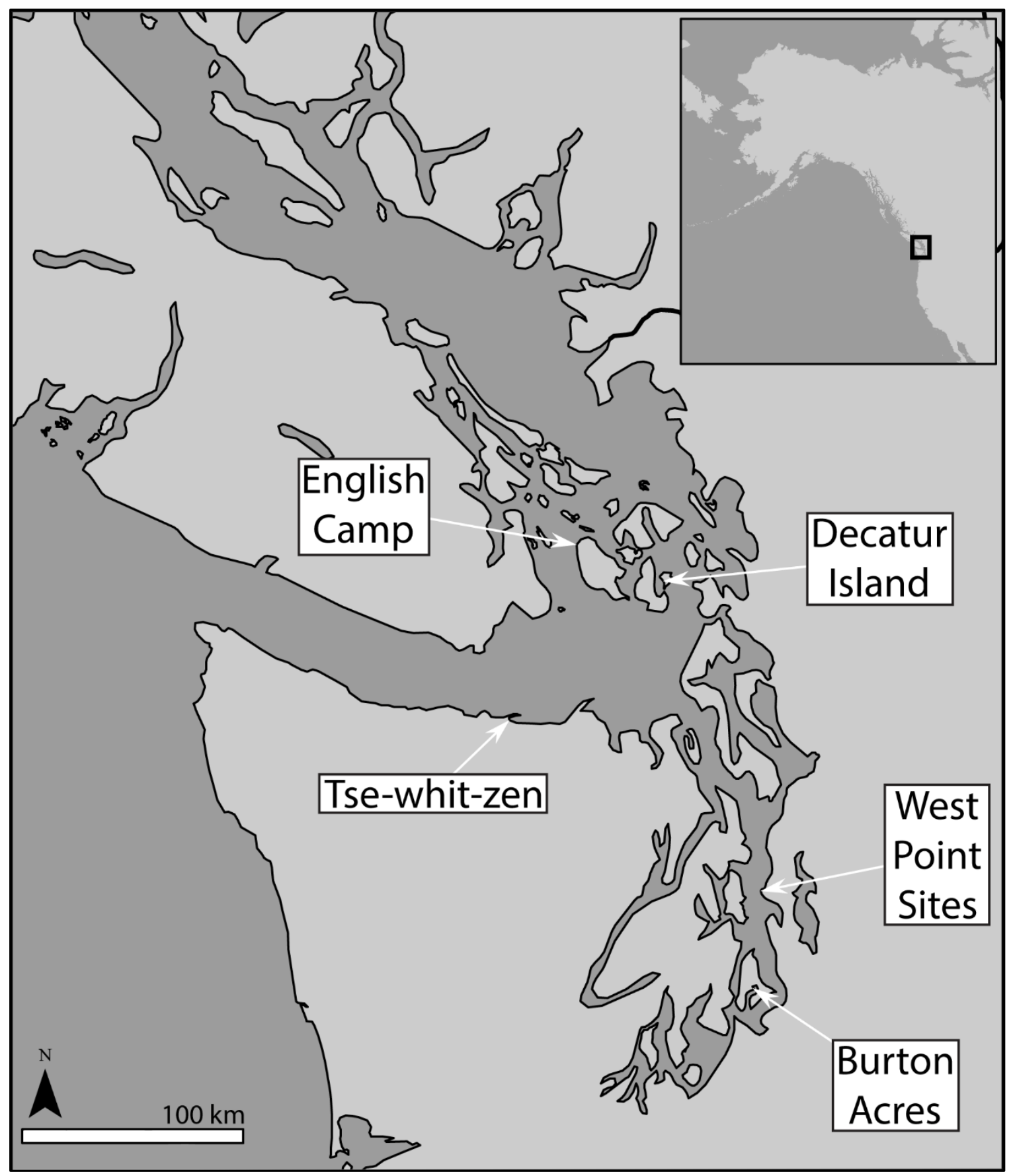

Figure 4 - Locations of archaeological sites selected for reanalysis. 
been confused for salmon (genus Oncorhynchus), sculpin (family Cottidae), or flatfish (order Pleuronectiformes) vertebrae, I only reanalyzed vertebral specimens from these assemblages.

Northwest Coast Fishbone Data Synthesis

I synthesized fishbone data from zooarchaeological reports for 24 archaeological sites (Table 5; Figure 5) to determine whether sablefish scarcity in the Northwest Coast can be explained by screen size effects $\left(\mathrm{H}_{2}\right)$, sample size $\left(\mathrm{H}_{3}\right)$, or post-depositional destruction $\left(\mathrm{H}_{4}\right)$. I chose reports that are cited by Butler and Campbell (2004) and McKechnie et al. (2014) in their syntheses of Northwest Coast animal bone records. I divided each site into the largest number of assemblages possible using previously defined chronological components for each site. Because sablefish is rarely reported, I only selected assemblages with at least 10 identified fish taxa (nTaxa) and a sample size of at least 100 NISP $_{\text {fishes }}$ to focus my analysis on sites with a relatively high probability of containing sablefish. I also excluded sites that were not sampled with $3.2 \mathrm{~mm}\left(1 / 8^{\prime \prime}\right)$ or finer mesh, with the exception of Hoko River Rockshelter which includes numerous sablefish specimens despite the exclusive use of coarse mesh.

For each chronological assemblage of each site, I attempted to record which mesh sizes were used to sample fish remains, $\mathrm{NISP}_{\text {sablefish }}, \mathrm{NISP}_{\text {fishes }}, \mathrm{NSP}_{\text {fishes }}$, and the volume (L) of excavated material that each fishbone assemblage represents (Table 5). I derived

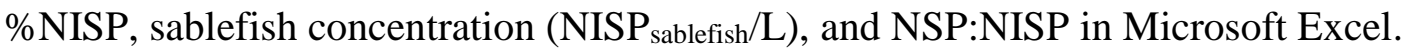
References and narrative descriptions of my data synthesis for each assemblage are reported in Appendix A. 
Table 5 - Fishbone data available from Northwest Coast archaeological assemblages. ("Sable." = Sablefish; "Vol." = Volume analyzed for fishbone)

\begin{tabular}{|c|c|c|c|c|c|c|c|}
\hline Site Name & $\begin{array}{c}\text { Site } \\
\text { Number }\end{array}$ & $\begin{array}{c}\text { Screen } \\
\text { Size }\end{array}$ & $\begin{array}{l}\text { NISP } \\
\text { Sable. }\end{array}$ & $\begin{array}{l}\text { NISP } \\
\text { Fish }\end{array}$ & $\begin{array}{l}\text { NSP } \\
\text { Fish }\end{array}$ & $\begin{array}{l}\text { Vol. } \\
\text { (L) }\end{array}$ & Source \\
\hline Kilisnoo Picnicground & 49SIT124 & $\mathrm{X}$ & $\mathrm{X}$ & $\mathrm{X}$ & $\mathrm{X}$ & & Moss (1989) \\
\hline Daax Haat Kanadaa & 49SIT244 & $\mathrm{X}$ & $\mathrm{X}$ & $\mathrm{X}$ & $\mathrm{X}$ & $\mathrm{X}$ & Moss (1989) \\
\hline $740 \mathrm{~T}$ & $740 \mathrm{~T}$ & $\mathrm{X}$ & $\mathrm{X}$ & $\mathrm{X}$ & $\mathrm{X}$ & $\mathrm{X}$ & Orchard (2007) \\
\hline 7aydi 'llnagaay & $717 \mathrm{~T}$ & $\mathrm{X}$ & $\mathrm{X}$ & $\mathrm{X}$ & $\mathrm{X}$ & & Orchard (2007) \\
\hline Kaidsu - Unit 1 & $781 \mathrm{~T}$ & $\mathrm{X}$ & $\mathrm{X}$ & $\mathrm{X}$ & $\mathrm{X}$ & & Orchard (2007) \\
\hline Q'iid 'llnagaay & $924 \mathrm{~T}$ & $\mathrm{X}$ & $\mathrm{X}$ & $\mathrm{X}$ & $\mathrm{X}$ & & Orchard (2007) \\
\hline Qayjuи 'Ilnagaay & 699T & $\mathrm{X}$ & $\mathrm{X}$ & $\mathrm{X}$ & $\mathrm{X}$ & & Orchard (2007) \\
\hline Хииd tsixwaas 'llnagaay & $785 \mathrm{~T}$ & $\mathrm{X}$ & $\mathrm{X}$ & $\mathrm{X}$ & $\mathrm{X}$ & $\mathrm{X}$ & Orchard (2007) \\
\hline Huu7ii - Back Terrace & DfSh 7 & $\mathrm{X}$ & $\mathrm{X}$ & $\mathrm{X}$ & $\mathrm{X}$ & $\mathrm{X}$ & McKechnie (2012) \\
\hline Huu7ii - House 1 & DfSh 7 & $\mathrm{X}$ & $\mathrm{X}$ & $\mathrm{X}$ & $\mathrm{X}$ & $\mathrm{X}$ & McKechnie (2012) \\
\hline Ts'ishaa - Main Village & DfSi 16 & $\mathrm{X}$ & $\mathrm{X}$ & $\mathrm{X}$ & $\mathrm{X}$ & $\mathrm{X}$ & McKechnie (2005) \\
\hline Ts'ishaa - Back Terrace & DfSi 16 & $\mathrm{X}$ & $\mathrm{X}$ & $\mathrm{X}$ & $\mathrm{X}$ & $\mathrm{X}$ & McKechnie (2005) \\
\hline Hoko River Rockshelter & 45CA21 & $\mathrm{X}$ & $\mathrm{X}$ & $\mathrm{X}$ & $\mathrm{X}$ & $\mathrm{X}$ & Wigen (2005) \\
\hline Cove Cliff Site & DhRr 18 & $\mathrm{X}$ & $\mathrm{X}$ & $\mathrm{X}$ & $\mathrm{X}$ & $\mathrm{X}$ & Trost (2005) \\
\hline Decatur Island - AU 2 & 45SJ169 & $\mathrm{X}$ & $\mathrm{X}$ & $\mathrm{X}$ & & & Wigen (2003) \\
\hline Decatur Island - AU 5 & 45SJ169 & $\mathrm{X}$ & $\mathrm{X}$ & $\mathrm{X}$ & & & Wigen (2003) \\
\hline Dionisio Point - Layer A & DgRv 3 & $\mathrm{X}$ & $\mathrm{X}$ & $\mathrm{X}$ & $\mathrm{X}$ & & Ewonus (2011) \\
\hline Dionisio Point - Layer B & DgRv 3 & $\mathrm{X}$ & $\mathrm{X}$ & $\mathrm{X}$ & $\mathrm{X}$ & & Ewonus (2011) \\
\hline Dionisio Point - Layer C & $\operatorname{DgRv} 3$ & $\mathrm{X}$ & $\mathrm{X}$ & $\mathrm{X}$ & $\mathrm{X}$ & & Ewonus (2011) \\
\hline Tum-tumay-whueton & DhRr 6 & $\mathrm{X}$ & $\mathrm{X}$ & $\mathrm{X}$ & $\mathrm{X}$ & $\mathrm{X}$ & Pierson (2011) \\
\hline Noons Creek & DhRq 1 & $\mathrm{X}$ & $\mathrm{X}$ & $\mathrm{X}$ & $\mathrm{X}$ & $\mathrm{X}$ & Pierson (2011) \\
\hline Bay Street - Comp 1 & $45 \mathrm{KP} 115$ & $\mathrm{X}$ & $\mathrm{X}$ & $\mathrm{X}$ & $\mathrm{X}$ & $\mathrm{X}$ & Butler and Baker (2002) \\
\hline Bay Street - Comp 2 & $45 \mathrm{KP} 115$ & $\mathrm{X}$ & $\mathrm{X}$ & $\mathrm{X}$ & $\mathrm{X}$ & $\mathrm{X}$ & Butler and Baker (2002) \\
\hline Bay Street - Comp 3 & $45 \mathrm{KP} 115$ & $\mathrm{X}$ & $\mathrm{X}$ & $\mathrm{X}$ & $\mathrm{X}$ & $\mathrm{X}$ & Butler and Baker (2002) \\
\hline Burton Acres & $45 \mathrm{KI} 437$ & $\mathrm{X}$ & $\mathrm{X}$ & $\mathrm{X}$ & $\mathrm{X}$ & $\mathrm{X}$ & Kopperl and Butler (2002) \\
\hline Cama Beach & 45IS2 & $\mathrm{X}$ & $\mathrm{X}$ & $\mathrm{X}$ & $\mathrm{X}$ & & Trost (2010) \\
\hline Duwamish & $45 \mathrm{KI} 23$ & $\mathrm{X}$ & $\mathrm{X}$ & $\mathrm{X}$ & & & Butler (1987) \\
\hline West Point 428 - Comp 1 & $45 \mathrm{KI} 428$ & $\mathrm{X}$ & $\mathrm{X}$ & $\mathrm{X}$ & $\mathrm{X}$ & $\mathrm{X}$ & Wigen (1995) \\
\hline West Point 428 - Comp 2 & $45 \mathrm{KI} 428$ & $\mathrm{X}$ & $\mathrm{X}$ & $\mathrm{X}$ & $\mathrm{X}$ & $\mathrm{X}$ & Wigen (1995) \\
\hline West Point 429 - Comp 1 & $45 \mathrm{KI} 429$ & $\mathrm{X}$ & $\mathrm{X}$ & $\mathrm{X}$ & $\mathrm{X}$ & $\mathrm{X}$ & Wigen (1995) \\
\hline West Point 429 - Comp 5 & $45 \mathrm{KI} 429$ & $\mathrm{X}$ & $\mathrm{X}$ & $\mathrm{X}$ & $\mathrm{X}$ & $\mathrm{X}$ & Wigen (1995) \\
\hline English Camp Op A & $45 \mathrm{SJ} 24$ & $\mathrm{X}$ & $\mathrm{X}$ & $\mathrm{X}$ & & & Pegg (1999) \\
\hline English Camp Op D & $45 \mathrm{SJ} 24$ & $\mathrm{X}$ & $\mathrm{X}$ & $\mathrm{X}$ & $\mathrm{X}$ & & Kopperl (2011) \\
\hline Loon Cave - Component I & DiSo 9 & $\mathrm{X}$ & $\mathrm{X}$ & $\mathrm{X}$ & & & Calvert (1980) \\
\hline Loon Cave - Component II & DiSo 9 & $\mathrm{X}$ & $\mathrm{X}$ & $\mathrm{X}$ & & & Calvert (1980) \\
\hline
\end{tabular}




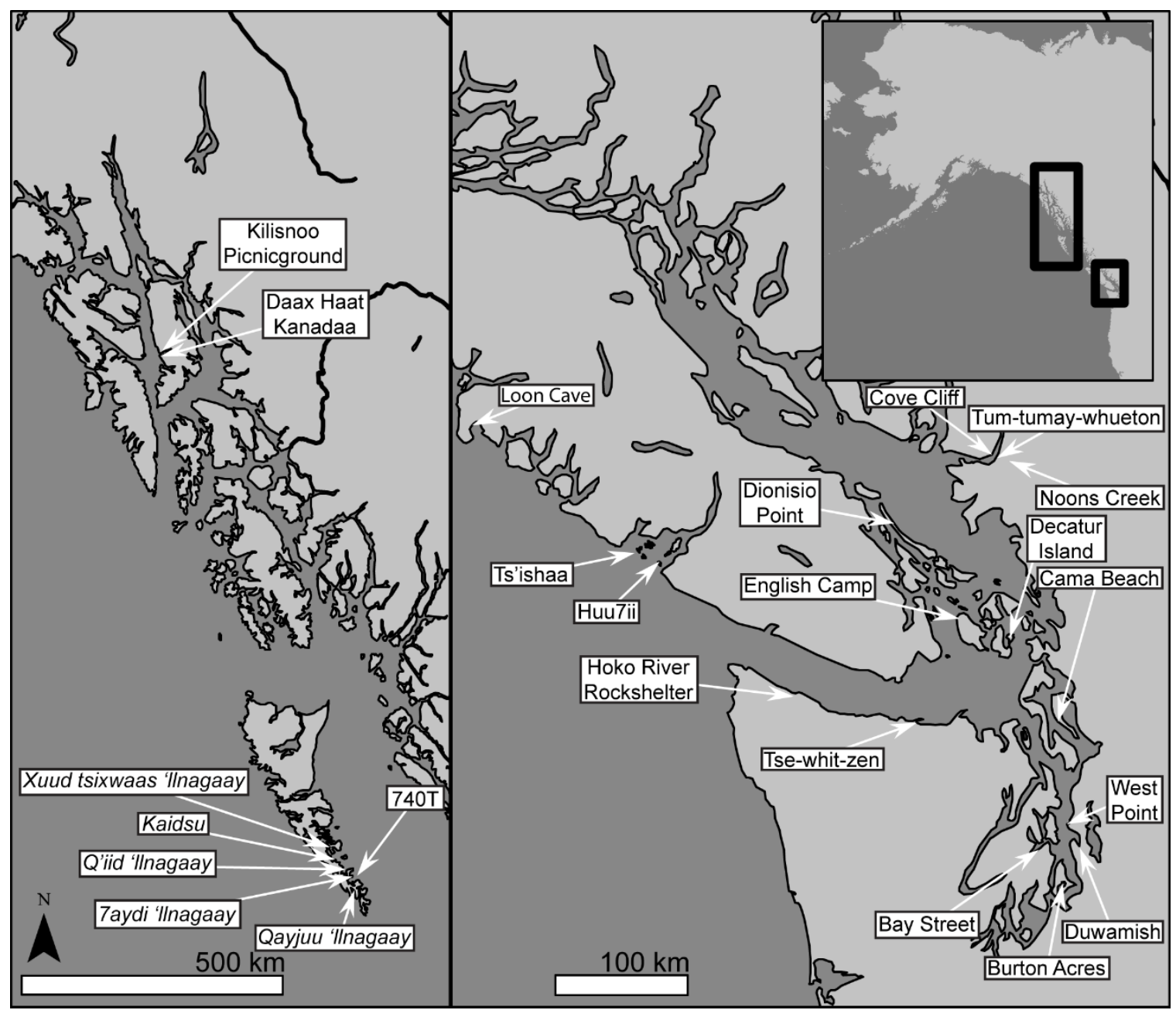

Figure 5 - Locations of sites included in the Northwest Coast fishbone data synthesis.

Tse-whit-zen

Data from the large scale analysis of Tse-whit-zen provides a unique opportunity to closely study the effects of recovery methods $\left(\mathrm{H}_{2}\right.$ and $\left.\mathrm{H}_{3}\right)$ and taphonomy $\left(\mathrm{H}_{4}\right)$ on sablefish representation, and reanalysis of the Tse-whit-zen assemblage allows me to verify that sablefish were identified consistently throughout the project $\left(\mathrm{H}_{1}\right)$. Tse-whitzen is a Lower Elwha Klallam Tribe (LEKT) village in Port Angeles, WA at the base of Ediz Hook on the south shore of the Strait of Juan de Fuca (Figure 5) that was occupied for the past 2,800 years (Larson 2006). In 2004, Larson Anthropological Archaeological 
Services (LAAS) and LEKT members excavated the site with large open blocks of $1 \mathrm{x} 1$ $\mathrm{m}$ units by natural stratigraphic layers that were subdivided into $10 \mathrm{~cm}$ arbitrary levels (Reetz et al. 2006:16, 19). All excavated matrix was collected in 10 L buckets and wetscreened with nested 1", 1/2", 1/4", and 1/8" mesh. The screened matrix of every twentieth bucket was designated a "complete" (“C”) bucket and collected for sorting in the field laboratory. The final bucket was also retained from any 1 x $1 \mathrm{~m}$ unit that produced less than 40 buckets of matrix to ensure that a $20 \%$ sample was collected from the entire site (Reetz et al. 2006:146). In 2010, Kristine Bovy (University of Rhode Island), Virginia Butler (Portland State University [PSU]), Sarah Campbell (Western Washington University), Michael Etnier (Western Washington University), and Sarah Sterling (PSU) initiated a large-scale zooarchaeological and geoarchaeological analysis of three structures at Tse-whit-zen.

The zooarchaeological data from Tse-whit-zen that I use in this thesis come from the unpublished results of the fishbone analysis led by Butler at PSU. The universe of taxa was established using the results of fisheries surveys from the Environmental Protection Agency and the National Oceanic and Atmospheric Administration published in Miller et al. (1980). The non-taxonomic group 'non-salmonid' was also used to record unidentifiable vertebra fragments that are definitively not from salmon in an effort to counter the potential over-documentation of salmon specimens, which can be easily identified to genus from very small vertebra fragments. The finest possible taxonomic and skeletal element attributions were recorded for each specimen along with its catalog number, provenience, screen-size fraction, the presence of morphological landmarks, and the presence of burning. Kathryn Mohlenhoff, Anthony Hofkamp, Shoshana Rosenberg, 
and I made identifications using the PSU Anthropology Department comparative collection, which was supplemented with species loaned to Butler by Bob Kopperl (Willamette Cultural Resources Associates) and Ross Smith (University of Oregon). Butler verified all identifications under magnification with a binocular loupe or microscope. To ensure that identification criteria remained consistent throughout the project, Butler and I carried out a reanalysis of identified Tse-whit-zen materials following protocol that I describe below ( $\mathrm{H}_{1}$ Methods).

The results I report in this thesis for Tse-whit-zen are aggregated by time period, or chronological zone. As of this writing, Sterling has defined six distinct chronological zones in Area A4 (Figure 6) of the site using the associations between microstrata identified in the field and approximately 100 radiocarbon dates (Butler, personal communication 2016). One of these chronological zones (CZ-4) is split into two assemblages (CZ-4a and CZ-4b) because it was excavated as two discrete portions. After fishbone data were recorded in Microsoft Excel, Kristina Dick (PSU) transferred the information to a central project database and assigned each specimen to a time period based on its provenience. I treat chronological zones as separate assemblages because they represent discrete deposits that may have experienced very different postdepositional histories.

Analysis of Tse-whit-zen materials collected as "C" buckets revealed discrepancies between the sizes of archaeological specimens in each bag and the recorded screen size on the bag label and in the Tse-whit-zen artifact catalog. For example, fish remains recorded as belonging to the $1 / 4$ " mesh fraction actually included much larger specimens that should have been captured by $1 / 2$ " mesh, and much smaller specimens 


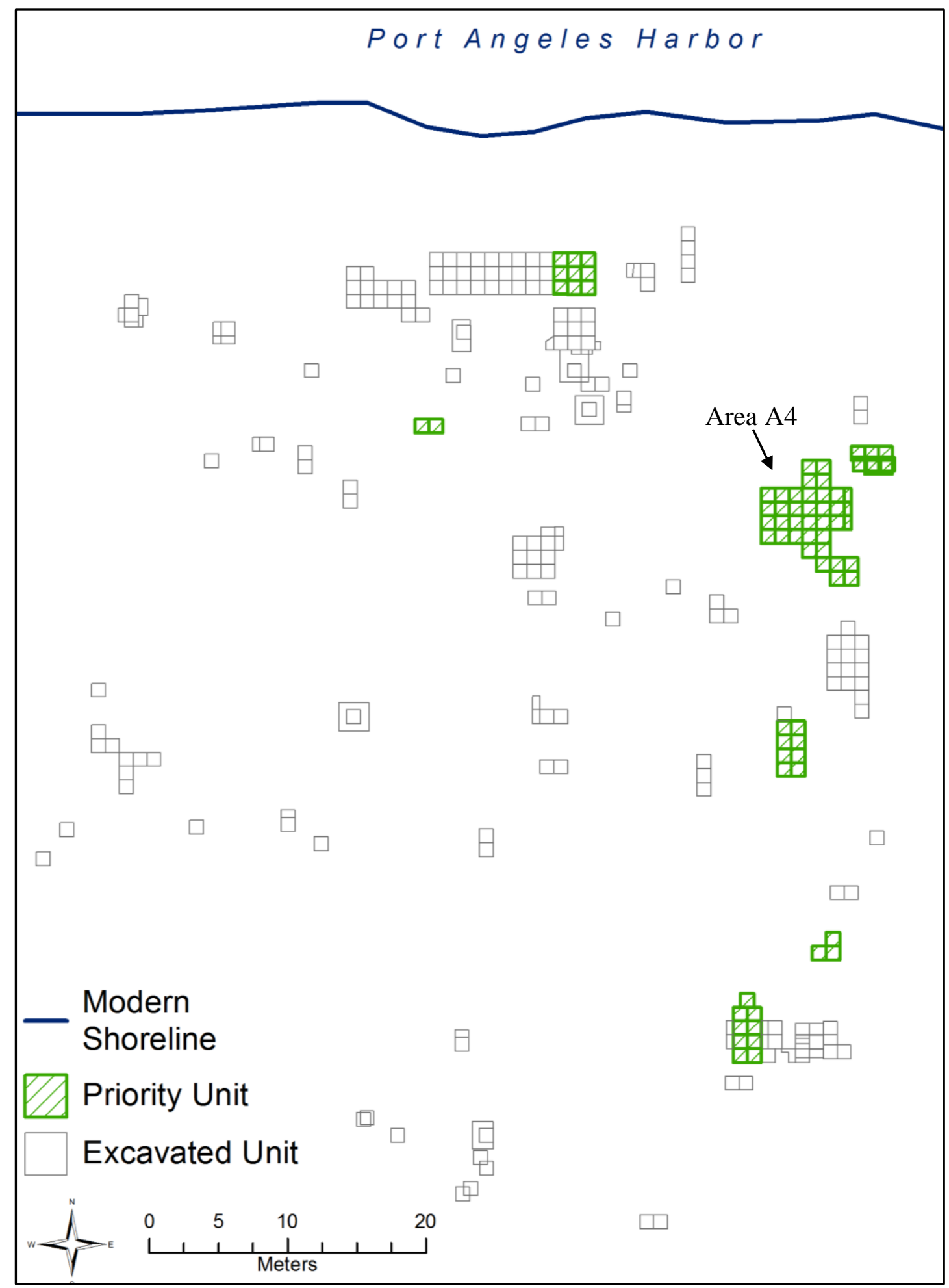

Figure 6 - Tse-whit-zen site map showing Area A4. Map by Kristina Dick (PSU). 
that should have fallen through to $1 / 8$ " mesh. To overcome this problem and ensure comparability with other Northwest Coast assemblages, Butler's lab staff re-screened all fishbone material into new $1 / 2 ", 1 / 4 "$, and $1 / 8$ " bags prior to analysis. Records of the Tsewhit-zen excavation indicate that $1 / 8$ " mesh was the finest screen size used for " $\mathrm{C}$ " buckets (Larson 2006), but almost every bucket also contained some fish remains that fell through $1 / 8$ " mesh. We retained this fishbone in bags that we labelled $<1 / 8$ " mesh. We do not know the size of the finest mesh used, but the number of bones in some $<1 / 8$ " bags was extremely high.

While the $<1 / 8$ " bags have largely been excluded from analysis given the questions regarding their recovery, Butler chose to analyze 14 bags from the $<1 / 8$ " fraction of area A4 for a crude assessment of whether anchovy (Engraulidae) could be abundant at Tse-whit-zen even though it is barely represented in the 1/8" screen fraction. Butler (personal communication, 2015) selected the $<1 / 8$ " bag from the bucket with the most herring (Clupea pallasii), and the $<1 / 8$ " bag from a bucket with a modest abundance of herring, for each chronological zone. Butler and I analyzed each bag using the same protocol as the original analysis, except that only vertebrae were recorded, and bags from

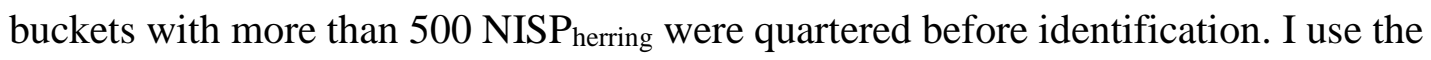
results of this analysis for a crude assessment of whether $3.2 \mathrm{~mm}\left(1 / 8^{\prime \prime}\right)$ mesh is adequate for sablefish recovery $\left(\mathrm{H}_{2}\right)$.

$\mathrm{H}_{1}$ Methods - Current identification criteria for sablefish are invalid or nonexistent If the morphological criteria used by regional zooarchaeologists to identify sablefish are nonexistent or invalid, sablefish remains may be systematically 
misidentified as other taxa. Because there are no identification criteria reported for this fish, I cannot determine how likely it is that sablefish have been misidentified from the literature alone.

To evaluate whether systematic misidentification accounts for sablefish scarcity, I reanalyzed portions of Tse-whit-zen and samples of vertebrae from Burton Acres, Decatur Island, English Camp, and West Point (both sites). Because sablefish vertebrae are morphologically similar to those of salmon (genus Oncorhynchus), sculpins (family Cottidae), and flatfishes (order Pleuronectiformes), I expect that sablefish vertebrae were misidentified as belonging to one or more of these taxa. For the reanalysis of previously analyzed sites, I recorded the number of vertebral specimens that I identified to these four taxa and the number of vertebrae recorded on bag labels for the same specimens by the original analysts in a $10 \%$ random sample of each assemblage. If the vertebrae counts in the original analysis and the reanalysis differ enough that they offer divergent interpretations of sablefish use at the sites I study, invalid or nonexistent identification criteria must be considered as explanations for sablefish scarcity.

I reanalyzed vertebrae from each of the six previously analyzed assemblages using the same protocol. First, I selected $10 \%$ of the excavation buckets containing 50 or more identified fish specimens according to random sequences generated by Random.org. A list of the buckets I selected for reanalysis is available in Appendix B. I excluded bags with small numbers of identified specimens so that I could focus my sampling effort on larger quantities of fishbone. After selecting a sample for re-analysis, I spread the faunal remains from individual screen-size fractions out on trays and sorted the material for vertebrae that were originally recorded as sablefish, salmon, sculpins, and flatfishes. I 
also took care to scan all other fishbone material for misidentified and unidentified sablefish specimens. Then I recorded the number of vertebrae and vertebral fragments specimens with less than half of the notochord - that I identified to these four taxa using identification criteria reported in Appendix C.

Many Pacific Northwest researchers have asserted that very small fragments of salmon vertebrae can be distinguished by a characteristic texture (Butler 2004:320; Ewonus 2011:86; Moss 2007:13; Pegg 1999:97). However, because vertebrae of several other species are characterized by similarly fenestrated textures, I only recorded salmonid specimens that possess a portion of the centrum lip, the base of the vertebral spine, or any part of the facet for the articulation of a vertebral spine (Figure 7). Any one of these landmarks definitively marks specimens as belonging to a salmonid. I was also conservative with my identifications of flatfish, sculpin, and sablefish vertebrae that derive from the extreme caudal end of the vertebral column. These specimens appear uniform across multiple taxonomic orders of class Osteichthyes and lack distinguishing features necessary to make confident taxonomic attributions. Therefore, I did not record these "too caudal" specimens in my tally of vertebrae for any taxon.

For each vertebral specimen, I recorded the site from which it originated, its provenience, and the screen-fraction to which it belongs. I returned all materials to their bags as I found them, with the exception of previously unidentified sablefish specimens, which I sub-bagged with a paper tag recording my attribution.

Unlike the other assemblages, which used a minimum screen size of $3.2 \mathrm{~mm}$, the Decatur Island fishbone was recovered in $6.4 \mathrm{~mm}\left(1 / 4^{\prime \prime}\right)$ and $1.5 \mathrm{~mm}\left(1 / 16^{\prime \prime}\right)$ screens. To ensure that inter-assemblage comparisons are valid for the Decatur Island materials, I re- 
screened the $1.5 \mathrm{~mm}$ fraction through $3.2 \mathrm{~mm}$ mesh and only counted the vertebrae collected in the $3.2 \mathrm{~mm}$ screen and $6.4 \mathrm{~mm}$ screen fractions. I also scanned the $<3.2 \mathrm{~mm}$ material for small sablefish remains. After my reanalysis, I returned the materials from the $3.2 \mathrm{~mm}$ mesh to the bags as I found them.

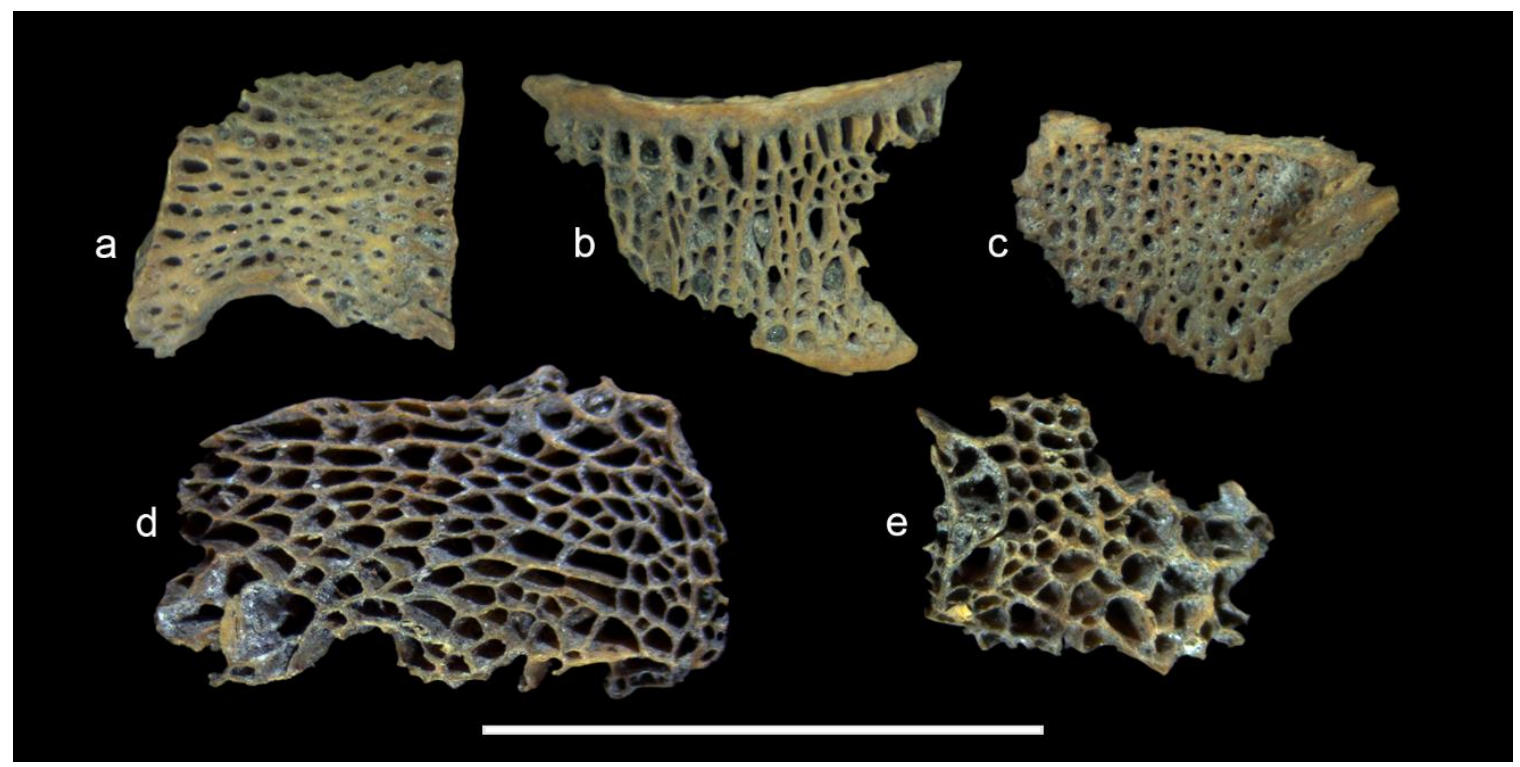

Figure 7 - Identifiable salmon vertebral fragments (top row) and unidentified fish bone specimens (bottom row). Salmonid fragments identified by a) vertebral spine facet, $b$ ) robust lip, and c) base of vertebral spine. Scale bar is $10 \mathrm{~mm}$. Photos by Tony Hofkamp. (Courtesy of the Thomas Burke Memorial Washington State Museum, catalog number WS-14677.99.08.23, Area A4, Unit 17)

I reanalyzed the Burton Acres, West Point, and English Camp assemblages at the Burke Museum in 2015 using sablefish, salmonid, staghorn sculpin, and starry flounder (Platichthys stellatus) comparative specimens from the PSU Anthropology Department comparative collection. I reanalyzed the Decatur Island assemblage using materials loaned to Butler by the Bonneville Power Administration in the PSU zooarchaeology lab with the entire PSU Anthropology Department comparative collection.

The Tse-whit-zen reanalysis was part of a larger study on the reliability of taxonomic attributions for fishbone. It therefore differs from the reanalysis of previously 
analyzed sites because it was designed to verify the identification criteria used for all fishes identified at the site. Butler and I randomly selected $10 \%$ of the buckets from excavation units that were analyzed at the beginning, middle, and end of the three-year analysis of fish remains (Appendix D) and reanalyzed them using the same protocol as the original analysis (see Tse-whit-zen above). I used Spearman's rank order correlation coefficient to test whether the rank order taxonomic abundance of sablefish is correlated in the reanalysis and the original analysis. If the rank order taxonomic abundance of sablefish is not statistically correlated in the results of the original analysis and the reanalysis, the identification criteria used for this species may not be valid, and the high frequency of sablefish at this site could be the result of misidentification.

$\mathrm{H}_{2}$ Methods - Excavators do not use suitably fine screen sizes to recover sablefish

Sablefish scarcity may be caused by the relatively small size of sablefish bones, especially if archaeologists only use $6.4 \mathrm{~mm}$ or larger mesh to recover fishbone assemblages. I evaluated the effects of screen-size empirically by comparing the frequencies of sablefish bones represented in different mesh-size fractions of nested screens from Tse-whit-zen and the synthesized Northwest Coast assemblages. The goal of this comparison is to determine which screen sizes are sufficiently fine to recover sablefish specimens. Because it is likely that small-bodied juvenile sablefish were captured (see Sablefish Ecology above), I expect $3.2 \mathrm{~mm}$ mesh is required to obtain an adequate sample of sablefish remains.

Nested screens were used to sample nearly every site, but Duwamish and Ts'ishaa are the only assemblages with taxonomic abundance data published for individual screen 
sizes. I was also able to derive individual screen size results for Burton Acres, Tse-whitzen, and West Point (both sites) using digital zooarchaeological databases from each of these sites. None of these assemblages have comparable samples of fishbone from screen size fractions finer than $3.2 \mathrm{~mm}$ mesh. However, I compared sablefish abundance in $<1 / 8$ " bags from Tse-whit-zen and the subsampled $1.5 \mathrm{~mm}\left(1 / 16^{\prime \prime}\right)$ mesh fraction from Ts'ishaa to the other screen size fractions of these assemblages to explore which screen sizes are sufficiently fine to obtain representative samples of sablefish remains. Then, I checked which assemblages were sampled using screens that are capable of recovering sablefish remains. If previously identified assemblages were not recovered using screens that retain sablefish remains, then screen-size effects cannot be ruled out as a factor in sablefish scarcity.

I also used Fisher's exact test to determine whether sablefish presence is associated with the use of mesh finer than $3.2 \mathrm{~mm}$. Like the Chi-square test, Fisher's exact test is used to evaluate the hypothesis that two categorical variables with $m$ and $n$ states are associated by calculating the probability $(p)$ that an $m \times n$ matrix formed by a sample of observed cases was not produced by chance alone (e.g. Table 6). If $p$ is less than the specified level of confidence ( $\alpha$ ), there is enough evidence to reject the null hypothesis that the two variables are not associated. Unlike the Chi-square test, Fisher's exact test is valid even when the number of expected cases in any given cell of the $m \times n$ table is less than five. Because very few assemblages were sampled with a minimum screen size finer than $3.2 \mathrm{~mm}$ mesh, Fisher's test is more appropriate for a comparison of sablefish presence in $3.2 \mathrm{~mm}$ mesh assemblages and assemblages sampled with finer mesh. I calculated $p$ for Fisher's test using SPSS, and I also report the effect size using 
the odds ratio (OR) - the odds that a positive result will be observed under a specified condition compared to the odds that it will be observed under normal conditions. The odds ratio is calculated as:

$$
\mathrm{OR}=\frac{a / b}{c / d}=\frac{(a \times d)}{(b \times c)}
$$

where $a, b, c$, and $d$ are the numbers of observed cases (assemblages in Table 6). If sablefish presence and the use of mesh finer than $3.2 \mathrm{~mm}$ are statistically correlated, then sablefish scarcity could be related to the small number of assemblages that were sampled with such fine mesh.

Table 6 - Model 2 × 2 matrix used for Fisher's exact test and to calculate odds ratio, where $a, b, c$, and $d$ are equal to the number of observed assemblages.

\begin{tabular}{lcc}
\hline $\begin{array}{c}\text { Min. Screen Size } \\
\text { Used }\end{array}$ & $\begin{array}{c}\text { Sablefish } \\
\text { Absent }\end{array}$ & $\begin{array}{c}\text { Sablefish } \\
\text { Present }\end{array}$ \\
\hline $2 \mathrm{~mm}$ or finer & $a$ & $b$ \\
$3.2 \mathrm{~mm}$ or coarser & $c$ & $d$ \\
\hline
\end{tabular}

$\mathrm{H}_{3}$ Methods - Sablefish is scarce because fishbone samples are too small

The stark differences in sablefish abundance at Tse-whit-zen and other Northwest Coast assemblages could be related to small volumes of excavated matrix in regional assemblages. To test this hypothesis, I used a method similar to the regression approach described by Lyman and Ames (2007; Lyman 2008:165) to compare the abundance of sablefish and the size of the fishbone sample for the assemblages of Tse-whit-zen and the regional synthesis. Instead of using linear regression to evaluate sample size effects, I used Spearman's rank order correlation coefficient. I compared sablefish abundance to 
two different measures of sample size: the volume of archaeological deposits analyzed for fishbone, and the NISP of fishes. Both are valid measures of sample size, but volume may be less reliable for identifying sample size effects because animal bone concentrations can vary dramatically within even a small deposit (Lyman 2008:149-150). Nevertheless, both volume and NISP may correlate with sablefish abundance, so I checked for a correlation in both. If sample size and sablefish rank-order abundance are statistically correlated by either measure, then sample size effects must be considered as an explanation for sablefish scarcity in regional assemblages.

$\mathrm{H}_{4}$ Methods - Sablefish bones are scarce due to post-depositional destruction

Sablefish skeletal elements are very fragile, with bone density that may be similar to or lower than salmon bone density. Because low density skeletal elements are more vulnerable to post-depositional destruction, archaeological assemblages that were subjected to more destructive processes would contain relatively fewer sablefish specimens even if numerous sablefish carcasses were originally deposited. Assemblages with less destructive taphonomic histories would have higher frequencies of sablefish.

To test for the existence this hypothetical relationship, I estimated the intensity of post-depositional destruction for each assemblage in Tse-whit-zen and the regional synthesis with the measure of fragmentation intensity $\mathrm{NSP}_{\text {fishes }}: \mathrm{NISP}_{\text {fishes. }}$ Then, I compared the relative abundance of sablefish to the intensity of fragmentation in each assemblage with Spearman's rank order correlation coefficient to see if these two 
variables are correlated. I used sablefish concentration ${ }^{*}-\mathrm{NISP}_{\text {sablefish }}$ per liter of analyzed archaeological matrix $\left(\mathrm{NISP}_{\text {sablefish }} / \mathrm{L}\right)$ - to control for sample size rather than the more commonly reported relative measure of abundance, $\% \mathrm{NISP}\left(\mathrm{NISP}_{\text {sablefish }} / \mathrm{NISP}_{\text {fishes }}\right)$ because \%NISP and NSP:NISP would necessarily co-vary. If there is a statistically significant relationship between sablefish concentration and fishbone fragmentation, post-depositional destruction must be considered as an explanation for the scarcity of sablefish.

\section{Analytic Challenges}

My goal to test whether sample volume and sablefish abundance are related was hampered because the volume of archaeological matrix that was analyzed for fishbone is not always reported. For some sites in the synthesis of regional fishbone data, the volume of fishbone that was studied is included with the publication (e.g. Ts'ishaa in McKechnie 2005:Table 5, 31). I was also able to estimate the volume of studied material from several other assemblages using other information reported with the site. For example, the volume analyzed from Tum-tumay-whueton and Noons Creek were not reported, but I use the dimensions of the samples collected from these sites to calculate volume, as Pierson (2011) analyzed 100\% of the recovered material (Appendix A). However, the volume of fishbone that was studied has not been reported, and cannot be estimated from the published information, for four sites (Table 7). In eight other sites, the reported volume estimates are not representative of the actual volume of analyzed material (Table

\footnotetext{
* Throughout, I refer to NISP/L as sablefish concentration rather than density to avoid confusion with measures of skeletal bone density $\left(\mathrm{g} / \mathrm{cm}^{3}\right)$.
} 
7). The fishbone analyzed from all of these sites was subsampled, but the volumes included with the fishbone analyses represent the volume of the assemblages prior to subsampling. Because these identified fishbone assemblages are representative of a smaller volume than the site reports indicate, I only include them in tests that do not require volume data $\left(\mathrm{H}_{2}\right.$ and $\mathrm{H}_{3}$ where sample size is measured as $\left.\mathrm{NISP}_{\text {fishes }}\right)$.

Table 7 - Analytic challenges for assemblages in the regional fishbone data synthesis.

\begin{tabular}{|c|c|c|c|c|}
\hline Site Name & $\begin{array}{l}\text { Volume Not } \\
\text { Reported }\end{array}$ & $\begin{array}{c}\text { Volume Not } \\
\text { Representative }\end{array}$ & $\begin{array}{c}\text { NISP } \\
\text { Inflated }\end{array}$ & $\begin{array}{l}\text { Protocol Not } \\
\text { Comparable }\end{array}$ \\
\hline$\overline{\text { Kilisnoo Picnicground }}$ & & $\bar{X}$ & & \\
\hline $\begin{array}{l}\text { Daax Haat Kanadaa } \\
740 \mathrm{~T}\end{array}$ & & & & \\
\hline 7aydi 'llnagaay & & $X$ & $X$ & \\
\hline Kaidsu & & $\mathrm{X}$ & $\mathrm{X}$ & \\
\hline Q'iid 'llnagaay & & $\mathrm{X}$ & $X$ & \\
\hline Qаујии 'llnagaay & & $X$ & $X$ & \\
\hline Xuud tsixwaas 'llnagaay & & & & \\
\hline Huu7ii & & & & \\
\hline Ts'ishaa & & & & \\
\hline Hoko River Rockshelter & & & & \\
\hline Cove Cliff Site & & & & $X$ \\
\hline Decatur Island & & $\mathrm{X}$ & & \\
\hline Dionisio Point & $\mathrm{X}$ & & & \\
\hline Tum-tumay-whueton & & & & \\
\hline Noons Creek & & & & \\
\hline Bay Street & & & & \\
\hline Burton Acres & & & & \\
\hline Cama Beach & $\mathrm{X}$ & & & $\mathrm{X}$ \\
\hline Duwamish & $\mathrm{X}$ & & & \\
\hline West Point 428 & & & & \\
\hline West Point 429 & & & & \\
\hline English Camp Op A & & $\mathrm{X}$ & & \\
\hline English Camp Op D & & $X$ & & \\
\hline Loon Cave & $\mathrm{X}$ & & & \\
\hline
\end{tabular}


Fishbone abundance was also inflated to correct for subsampling in four of these assemblages (Table 7). For the 7aydi 'llnagaay, Kaidsu, Q'iid 'llnagaay, and Qayjuu 'llnagaay assemblages, Orchard (2007) analyzed only a quarter of the fishbone by volume in some contexts. In an attempt to report taxonomic abundance data that are representative of the excavated volumes for these sites, Orchard quadrupled the observed NISP values of all fishes in the subsampled contexts (Appendix A). Because the actual abundances of fishbone recorded in these sites cannot be determined, I only include them in nominal scale hypothesis tests for screen size $\left(\mathrm{H}_{2}\right)$.

Taxonomic abundances from at least two sites are not comparable to the other assemblages in the regional fishbone data synthesis because fishbone was identified according to different protocol than any of the others. Fish vertebrae from Cove Cliff were only identified if the rostral face, the caudal face, and a portion of the centrum, were present (Appendix A), causing NISP to be underestimated relative to other assemblages that have all vertebral specimens identified. In the Cove Cliff and Cama Beach assemblages, only a select range of skeletal elements was identified (Appendix A), causing NISP to be dramatically underestimated relative to other assemblages in which every element except fin rays and ribs was identified. Both of these decisions are justifiable and serve particular research interests (Trost 2005, 2010), but data from these assemblages cannot be directly compared to other sites that used different identification protocols. Therefore, I only include them in nominal scale hypothesis tests $\left(\mathrm{H}_{2}\right)$. It should also be noted that Cove Cliff and Cama Beach are the only two assemblages for which differences in identification protocol have been reported. Considering the absence of methodological descriptions for zooarchaeological research 
throughout the region (Table 1), it is possible that important protocol differences exist for other assemblages as well, and that their results are not comparable to one another. For the purposes of this thesis, I assume that previously analyzed assemblages were analyzed for the same range of elements using the same criteria as one another. 


\section{Chapter 4: Hypothesis Tests and Results}

$\mathrm{H}_{1}$ Results - Current identification criteria for sablefish are invalid or nonexistent

To verify the validity of sablefish identification criteria, I reanalyzed a portion of

the Tse-whit-zen fishbone material, and $10 \%$ of the previously identified fishbone from six assemblages: Burton Acres, Decatur Island (45KI429 only), English Camp (Op A and Op D), and West Point (both sites). I expect that sablefish vertebrae were misidentified as belonging to one or more taxa with similarly fenestrated vertebrae (salmonids [genus Oncorhynchus], sculpins [family Cottidae], and flatfishes [order Pleuronectiformes]). If sablefish rank order abundance is not statistically correlated in the original analysis and reanalysis of Tse-whit-zen, the identification criteria used for this species in the Tse-whitzen analysis may not be valid, and the high frequency of sablefish at this site could be the result of misidentification. If reanalysis of previously analyzed assemblages shows that sablefish is actually abundant, then invalid or nonexistent identification criteria must be considered as an explanation for sablefish scarcity.

Sablefish abundance is extremely similar in the original analysis and the reanalysis of Tse-whit-zen, indicating that identification criteria used in the Tse-whit-zen project are valid (Appendix E: Supplemental Data File). The reanalyzed sample consists

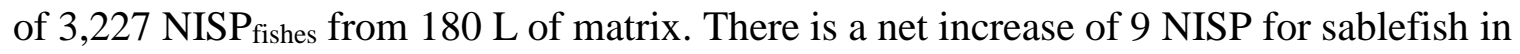
the reanalysis from the 94 specimens identified in the original analysis (Table 8). The new sablefish specimens were originally attributed to staghorn sculpin (Leptocottus armatus; $\mathrm{n}=5)$, family Cottidae $(\mathrm{n}=1)$, and the non-taxonomic group non-salmonid $(\mathrm{n}=$ 3; see Chapter 3: Tse-whit-zen for explanation of this group). Butler and I also identified 
Table 8 - Rank order comparison of taxonomic abundance at the family level from the original analysis and reanalysis of a sample of the Tse-whit-zen fishbone assemblage.

\begin{tabular}{|c|c|c|c|c|c|}
\hline Common Name & Taxon & $\begin{array}{l}\text { Original } \\
\text { NISP }\end{array}$ & $\begin{array}{c}\text { Original } \\
\text { Rank }\end{array}$ & $\begin{array}{l}\text { Reanalysis } \\
\text { NISP }\end{array}$ & $\begin{array}{c}\text { Reanalysis } \\
\text { Rank }\end{array}$ \\
\hline Herrings and Anchovies & Clupeiformes* & 2,259 & 1 & 2,296 & 1 \\
\hline Flatfishes & Pleuronectiformes* & 229 & 2 & 234 & 2 \\
\hline Sculpins & Cottidae & 201 & 3 & 201 & 3 \\
\hline Cods & Gadidae & 162 & 4 & 174 & 4 \\
\hline Sablefish & Anoplopomatidae & 94 & 5 & 103 & 5 \\
\hline Salmon and Trout & Salmonidae & 79 & 6 & 85 & 6 \\
\hline Dogfish Sharks & Squalidae & 59 & 7 & 60 & 7 \\
\hline Surfperches & Embiotocidae & 16 & 8 & 17 & 8.5 \\
\hline Rays & Rajidae & 14 & 9 & 13 & 10 \\
\hline Sharks and Rays & Elasmobranchii** & 12 & 10 & 17 & 8.5 \\
\hline Ratfishes & Chimaeridae & 10 & 11 & 10 & 12 \\
\hline Greenlings and Lingcod & Hexagrammidae & 6 & 12 & 12 & 11 \\
\hline Rockfishes & Scorpaenidae & 3 & 13 & 5 & 13 \\
\hline & $\begin{array}{r}\text { Grand Total } \\
\text { Volume Reanalyzed }\end{array}$ & $\begin{array}{r}3144 \\
180 \mathrm{~L}\end{array}$ & & $3227^{\dagger}$ & \\
\hline
\end{tabular}

*Taxonomic order, not family.

***Taxonomic subclass, not family.

${ }^{\dagger}$ Additional identified specimens in the reanalysis were originally recorded as non-salmon or unidentified fish, and not counted towards NISP.

one vertebra each from the order Pleuronectiformes and the family Cottidae that were originally identified as sablefish. In the reanalysis, we also counted three sablefish first vertebrae in a bag that was originally recorded as containing only one first vertebra.

Despite these differences, comparing rank order abundance of fishes at the taxonomic family* level shows the results of the original analysis and the reanalysis are highly correlated $\left(r_{s}=0.985 ; \mathrm{n}=13 ; \mathrm{P}<0.001\right)$. In addition, over $95 \%$ of the variability in the reanalysis results can be explained by the results of the original analysis $\left(r_{s}^{2}=0.970\right)$.

\footnotetext{
* I analyze flatfishes at the order level (Pleuronectiformes) because skeletal elements from member families Paralichthyidae (formerly Bothidae) and Pleuronectidae cannot always be distinguished with confidence. I analyze herrings and anchovies at the order level (Clupeiformes), even though only three anchovy (family Engraulidae) specimens have been identified at Tse-whit-zen because the elements of the otic series could not be identified to the family level with confidence. However, all Clupeiformes specimens almost certainly derive from the Pacific herring (Clupea pallasii). Sub-class Elasmobranchii is included because some fragmentary dogfish shark (family Squalidae) and ray (family Rajidae) vertebrae cannot be definitively identified to either family.
} 
The extremely strong correspondence between these two data sets indicates that sablefish abundance has not been inflated at Tse-whit-zen by identification errors.

Identification errors also cannot account for sablefish scarcity in the six

Northwest Coast assemblages that I reanalyzed (Appendix F: Supplemental Data File).

There is no evidence of sablefish use in the original analysis or the reanalysis of vertebrae from Burton Acres ( $\mathrm{n}$ [number of vertebrae examined] = 252), Decatur Island $(\mathrm{n}=91)$, or English Camp (Op A [n= 253] and Op D [n= 325]) (Table 9). In the West Point (45KI429) assemblage, I identified a single sablefish vertebra that Wigen attributed to staghorn sculpin. Our identifications agreed for all 11 previously identified sablefish vertebrae in the West Point (45KI428 [n=311] and 45KI429 [n=247]) assemblages. There is no indication that sablefish was systematically misidentified at any of these sites. While sablefish abundance did not change with reanalysis, other taxa do show some shifts in the number of vertebral specimens counted in the original analysis and the reanalysis. At Burton Acres, English Camp (Op A and Op D), and West Point (both sites), I counted markedly fewer salmonid vertebrae than the other analysts, and sculpin

Table 9 - Original ("1st") and reanalysis ("2nd") counts of vertebral specimens recorded for a $10 \%$ sample of six fishbone assemblages.

\begin{tabular}{|c|c|c|c|c|c|c|c|c|c|}
\hline \multirow{2}{*}{ Site } & \multicolumn{2}{|c|}{ Sablefish } & \multicolumn{2}{|c|}{ Sculpin } & \multicolumn{2}{|c|}{ Flatfish } & \multicolumn{2}{|c|}{ Salmon } & \multirow{2}{*}{$\begin{array}{l}\text { Vol. } \\
(\mathbf{L})\end{array}$} \\
\hline & 1st & 2nd & 1st & 2nd & 1 st & 2nd & 1st & 2nd & \\
\hline Burton Acres & 0 & 0 & 1 & 0 & 23 & 13 & 228 & 195 & $10-40 *$ \\
\hline Decatur Island & 0 & 0 & 15 & 13 & 14 & 14 & 62 & 63 & 58 \\
\hline English Camp Op A & 0 & 0 & 47 & 30 & 9 & 13 & 197 & 153 & 96 \\
\hline English Camp Op D & 0 & 0 & 23 & 18 & 1 & 1 & 301 & 240 & 96 \\
\hline West Point 428 & 1 & 1 & 32 & 25 & 85 & 74 & 193 & 133 & 140 \\
\hline West Point 429 & 10 & 11 & 52 & 37 & 71 & 62 & 114 & 80 & 140 \\
\hline
\end{tabular}


counts differ noticeably as well (Table 9). The greatest differences are in the English Camp Op D and West Point (45KI428) assemblages, where I counted 61 and 60 fewer salmonid vertebral specimens, respectively. The disagreements about the number of salmon vertebrae likely result from differences in the morphological criteria that I (Appendix C) and the other analysts used. The number of salmonid vertebrae missing from the reanalysis counts for each site is almost exclusively made up of fenestrated fishbone fragments bagged with salmon that I did not count because they did not have a distinct centrum lip, the base of a distinctive vertebral spine, or any part of the facet for the articulation of a vertebral spine (Table 10). Similarly, the number of missing sculpin vertebrae is largely accounted for by the vertebrae I did not count because they come from the extreme caudal end of the vertebral column (Table 10). These extremely caudal vertebrae lack distinctive morphological landmarks, and I do not identify them to family according to my criteria. However, if these vertebra counts are compared at the ordinal level, as they should be, there is virtually no change between the original results and the reanalysis (Table 9). Overall, I found some discrepancies in identification criteria, but they do not change taxonomic abundance enough to affect interpretations of fish use at these sites.

$\mathrm{H}_{2}$ Results - Excavators do not use suitably fine screen sizes to recover sablefish

To evaluate whether sablefish scarcity could be the result of screen size biases, I compared the abundances of sablefish remains represented in different mesh-size fractions of nested screens at Tse-whit-zen and previously identified Northwest Coast 
Table 10 - Original ("1st") and reanalysis ("2nd") vertebrae counts for salmonids and cottids. "Fenest. Texture" refers to specimens originally recorded as salmon vertebrae that have a fenestrated texture but no morphological landmarks. "Too Caudal" refers to specimens originally recorded as a member of family Cottidae that were too caudal to identify to family (Appendix C).

\begin{tabular}{ccrrrrrr}
\hline Site & Analysis & Salmon & $\begin{array}{c}\text { Fenest. } \\
\text { Texture }\end{array}$ & Total & Sculpin & $\begin{array}{c}\text { Too } \\
\text { Caudal }\end{array}$ & Total \\
\hline Burton & 1st & 228 & & 228 & 1 & & 1 \\
Acres & 2nd & 195 & 32 & 227 & 0 & 0 & 0 \\
Decatur & 1st & 62 & & 62 & 15 & & 15 \\
Island & 2nd & 63 & 0 & 63 & 13 & 1 & 14 \\
English & 1st & 197 & & 197 & 47 & & 47 \\
Camp Op A & 2nd & 153 & 40 & 193 & 23 & 3 & 26 \\
English & 1st & 301 & & 301 & 23 & & 23 \\
Camp Op D & 2nd & 239 & 59 & 298 & 16 & 3 & 19 \\
West Point & 1st & 193 & & 193 & 33 & & 33 \\
428 & 2nd & 133 & 57 & 190 & 26 & 4 & 30 \\
West Point & 1st & 114 & & 114 & 51 & & 51 \\
429 & 2nd & 79 & 34 & 113 & 36 & 7 & 43 \\
\hline
\end{tabular}

assemblages. The purpose of this comparison was to determine which mesh sizes are sufficiently fine to recover sablefish remains. Then, I checked which assemblages were sampled with screens that are sufficiently fine to recover sablefish bones. If Northwest Coast assemblages were predominately sampled with coarse-mesh screens that do not collect sablefish remains, then screen-size effects cannot be ruled out as a factor in sablefish scarcity.

Most sablefish remains are recovered in $3.2 \mathrm{~mm}\left(1 / 8^{\prime \prime}\right)$ or finer mesh. Three sites with taxonomic abundance data reported for individual screen sizes contain sablefish, which is overwhelmingly represented in the $3.2 \mathrm{~mm}$ fraction (Table 11). No sablefish were recovered in the $12.8 \mathrm{~mm}(1 / 2$ ”) fraction, but nine were recovered from the $6.4 \mathrm{~mm}$ 
Table 11 - Sablefish representation in individual screen size fractions from Northwest Coast assemblages. ("Sable" = Sablefish; "n/a" indicates a given mesh size was not used)

\begin{tabular}{|c|c|c|c|c|c|c|c|}
\hline \multirow[b]{2}{*}{ Site } & \multicolumn{2}{|c|}{$12.8 \mathrm{~mm}$} & \multicolumn{2}{|c|}{$6.4 \mathrm{~mm}$} & \multicolumn{2}{|c|}{$3.2 \mathrm{~mm}$} & \multirow[b]{2}{*}{ Vol. (L) } \\
\hline & $\begin{array}{l}\text { NISP } \\
\text { Sable } \\
\end{array}$ & $\begin{array}{c}\text { NISP } \\
\text { Fish } \\
\end{array}$ & $\begin{array}{l}\text { NISP } \\
\text { Sable } \\
\end{array}$ & $\begin{array}{c}\text { NISP } \\
\text { Fish } \\
\end{array}$ & $\begin{array}{l}\text { NISP } \\
\text { Sable } \\
\end{array}$ & $\begin{array}{c}\text { NISP } \\
\text { Fish } \\
\end{array}$ & \\
\hline Burton Acres & 0 & 11 & 0 & 324 & 0 & 4,935 & 462 \\
\hline Duwamish & $\mathrm{n} / \mathrm{a}$ & $\mathrm{n} / \mathrm{a}$ & 0 & 403 & 0 & 3,596 & unk. \\
\hline Tse-whit-zen - CZ-7 & 0 & 4 & 1 & 147 & 100 & 684 & 120 \\
\hline Tse-whit-zen - CZ-6 & 0 & 38 & 3 & 1,075 & 1,281 & 25,093 & 960 \\
\hline Tse-whit-zen - CZ-5 & 0 & 24 & 1 & 487 & 883 & 5,890 & 690 \\
\hline Tse-whit-zen - CZ-4a & 0 & 6 & 0 & 141 & 253 & 1,330 & 490 \\
\hline Tse-whit-zen - CZ-4b & 0 & 12 & 0 & 169 & 108 & 889 & 120 \\
\hline Tse-whit-zen - CZ-3 & 0 & 2 & 0 & 79 & 85 & 553 & 260 \\
\hline Tse-whit-zen - CZ-2 & 0 & 1 & 0 & 43 & 18 & 226 & 260 \\
\hline Ts'ishaa - Main Village & $\mathrm{n} / \mathrm{a}$ & $\mathrm{n} / \mathrm{a}$ & 4 & 745 & 18 & 4,040 & 115 \\
\hline Ts'ishaa - Back Terrace & $\mathrm{n} / \mathrm{a}$ & $\mathrm{n} / \mathrm{a}$ & 0 & 72 & 1 & 1,181 & 33 \\
\hline West Point 428 - Comp 1 & 0 & 7 & 0 & 357 & 0 & 2,048 & 870 \\
\hline West Point 428 - Comp 2 & 0 & 58 & 0 & 429 & 0 & 1,346 & 690 \\
\hline West Point 429 - Comp 1 & 0 & 1 & 0 & 114 & 7 & 437 & 220 \\
\hline West Point 429 - Comp 5 & 0 & 0 & 0 & 111 & 0 & 677 & 200 \\
\hline Hoko River Rockshelter & $\mathrm{n} / \mathrm{a}$ & $\mathrm{n} / \mathrm{a}$ & 103 & 48,353 & $\mathrm{n} / \mathrm{a}$ & $\mathrm{n} / \mathrm{a}$ & 17,5000 \\
\hline Total & 0 & 164 & 112 & 53,049 & 2754 & 52,925 & 18,0490 \\
\hline \% NISP Sable. in Screen & 0.0 & & 0.2 & & 5.2 & & \\
\hline
\end{tabular}

(1/4") fraction of Tse-whit-zen and Ts'ishaa. All remaining sablefish (NISP = 2753) from Tse-whit-zen, Ts'ishaa, and the sablefish from West Point were recovered in the $3.2 \mathrm{~mm}$ fraction (Table 11). Sablefish is also reasonably well represented at Hoko River Rockshelter, despite the exclusive use of $6.4 \mathrm{~mm}$ screens to recover that assemblage (Croes 2005:24). Overall, however, sablefish relative abundance (\%NISP) is much lower in the coarse mesh assemblages than in the $3.2 \mathrm{~mm}$ fraction (Table 11), indicating that fine mesh is necessary to recover large quantities of sablefish remains.

Screens finer than $3.2 \mathrm{~mm}$ mesh are no more likely to recover sablefish than 3.2 mm screens. Of the 11 assemblages in the regional fishbone synthesis that were screened with a minimum mesh size of $2 \mathrm{~mm}$ or finer, only three contain sablefish (Table 12). Assemblages screened with a minimum mesh size of $3.2 \mathrm{~mm}$ or coarser have a nearly equal chance of having sablefish or not having sablefish. The odds ratio $(\mathrm{OR}=0.352)$ 
Table 12 - Number of assemblages from Tse-whit-zen and regional fishbone data synthesis containing sablefish by minimum screen size used.

\begin{tabular}{lcc}
\hline $\begin{array}{c}\text { Min. Screen Size } \\
\text { Used }\end{array}$ & $\begin{array}{c}\text { Sablefish } \\
\text { Absent }\end{array}$ & $\begin{array}{c}\text { Sablefish } \\
\text { Present }\end{array}$ \\
\hline $2 \mathrm{~mm}$ or finer & 8 & 3 \\
$3.2 \mathrm{~mm}$ or coarser & 15 & 16 \\
\hline
\end{tabular}

indicates that assemblages screened with a minimum of $3.2 \mathrm{~mm}$ or coarser mesh are actually 2.8 times more likely to contain sablefish than assemblages screened with finer mesh, though the results of Fisher's exact test show that these differences are not statistically significant $(p=0.291)$. The small sample $(4.0 \mathrm{~L})$ of material from Ts'ishaa that McKechnie (2005:Table 8, 34) screened through 1/16" mesh also contained no sablefish, even though sablefish was recorded in the $3.2 \mathrm{~mm}$ and $6.4 \mathrm{~mm}$ fractions of the same column samples.

While $3.2 \mathrm{~mm}$ mesh is sufficient to recover sablefish remains, this mesh size appears to be biased against the recovery of vertebrae from younger, smaller-bodied juveniles. Analysis of fish vertebrae in $<1 / 8$ " bags from Tse-whit-zen shows that finer mesh is required to sample the full size-range of sablefish specimens. Sablefish is well represented in the $3.2 \mathrm{~mm}$ mesh fraction (NISP $=226$ ) of buckets that were analyzed for $<1 / 8$ " bags (Table 13 ). But the $<1 / 8$ " sample also contains a relatively large number of sablefish vertebral specimens (NISP $=135)$. Vertebral specimens small enough to fall through $3.2 \mathrm{~mm}$ mesh represent over one-third (37.3\%) of the sablefish vertebrae from these buckets.

Sablefish is captured by $3.2 \mathrm{~mm}$ mesh, and all sites in the regional fishbone data synthesis except Hoko River were sampled using $3.2 \mathrm{~mm}$ or finer mesh. Sablefish was 
Table 13 - Sablefish abundance by screen size in buckets with analyzed $<1 / 8$ " bags from Tse-whit-zen. NISP counts are for vertebrae only. ("Sable." = sablefish)

\begin{tabular}{|c|c|c|c|c|c|c|c|c|c|}
\hline \multirow[b]{2}{*}{$\begin{array}{c}\text { Chronological } \\
\text { Zone }\end{array}$} & \multicolumn{2}{|c|}{$12.8 \mathrm{~mm}$} & \multicolumn{2}{|c|}{$6.4 \mathrm{~mm}$} & \multicolumn{2}{|c|}{$3.2 \mathrm{~mm}$} & \multicolumn{2}{|c|}{$<1 / 8$} & \multirow[b]{2}{*}{$\begin{array}{l}\text { Vol. } \\
\text { (L) }\end{array}$} \\
\hline & $\begin{array}{l}\text { NISP } \\
\text { Sable. }\end{array}$ & $\begin{array}{c}\text { NISP } \\
\text { Fish } \\
\end{array}$ & $\begin{array}{l}\text { NISP } \\
\text { Sable. }\end{array}$ & $\begin{array}{c}\text { NISP } \\
\text { Fish }\end{array}$ & $\begin{array}{l}\text { NISP } \\
\text { Sable. }\end{array}$ & $\begin{array}{l}\text { NISP } \\
\text { Fish } \\
\end{array}$ & $\begin{array}{l}\text { NISP } \\
\text { Sable. }\end{array}$ & $\begin{array}{c}\text { NISP } \\
\text { Fish } \\
\end{array}$ & \\
\hline CZ-7 & 0 & 1 & 1 & 14 & 39 & 342 & 26 & 185 & 20 \\
\hline CZ-6 & 0 & 0 & 0 & 22 & 25 & 2,594 & 30 & 2,523 & 20 \\
\hline CZ-5 & 0 & 1 & 0 & 14 & 19 & 676 & 11 & 587 & 20 \\
\hline CZ-4a & 0 & 2 & 0 & 15 & 76 & 383 & 45 & 405 & 20 \\
\hline$C Z-4 b$ & 0 & 3 & 0 & 4 & 32 & 427 & 7 & 126 & 20 \\
\hline CZ-3 & 0 & 0 & 0 & 19 & 28 & 215 & 14 & 194 & 20 \\
\hline $\mathrm{CZ}-2$ & 0 & 0 & 0 & 22 & 7 & 71 & 2 & 105 & 20 \\
\hline Total & 0 & 7 & 1 & 110 & 226 & 4,708 & 135 & 4,125 & 140 \\
\hline in Screen & 0.0 & & 0.9 & & 6.3 & & 3.3 & & \\
\hline
\end{tabular}

even collected in $6.4 \mathrm{~mm}$ screens at Hoko River and Tse-whit-zen, but it is absent from more than half of the assemblages in the regional synthesis. Smaller vertebrae from younger individuals are also recovered in mesh finer than $3.2 \mathrm{~mm}$. Because most Northwest Coast assemblages were sampled with $3.2 \mathrm{~mm}$ mesh, these records may not reflect the occurrence of the youngest sablefish. However, the assemblages that were sampled with $2 \mathrm{~mm}, 1.5 \mathrm{~mm}\left(1 / 16^{\prime \prime}\right)$, and $1 \mathrm{~mm}$ screens are not any more likely to contain sablefish than assemblages that were sampled with a minimum screen size of 3.2 mm mesh.

$\mathrm{H}_{3}$ Results - Sablefish is scarce because fishbone samples are too small

Sablefish could be more abundant at Tse-whit-zen than other sites because it represents a larger sample of identified fishbone. I used Spearman's rank order correlation to compare the abundance of sablefish and the size of fishbone samples for each chronological zone of Tse-whit-zen and the synthesized Northwest Coast fishbone 
assemblages. I measured sample size using both NISP $_{\text {fishes }}$ and volume (L). If either measure of sample size is statistically correlated with sablefish abundance, then sample size effects must be considered as a possible explanation for the scarcity of sablefish.

There is no relationship between sablefish abundance and sample size in Northwest Coast fishbone assemblages. While sablefish abundance appears to increase with sample size at Tse-whit-zen, sablefish is absent or barely represented in all other

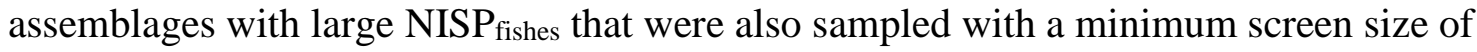
$3.2 \mathrm{~mm}$ mesh (Table 14; Figure 8). Calculating Spearman's correlation coefficient shows

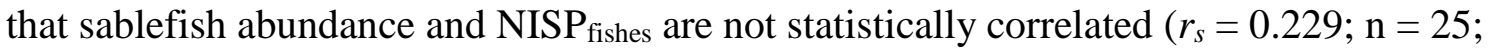
$p=0.271)$, and $\mathrm{NISP}_{\text {fishes }}$ can only explain $5 \%$ of the variation in $\mathrm{NISP}_{\text {sablefish }}\left(r_{s}^{2}=\right.$ $0.052)$.

When sample size is measured in terms of volume for assemblages sampled with a minimum screen size of $3.2 \mathrm{~mm}$ mesh, sablefish is again absent from several large assemblages (Table 14; Figure 9). The relationship between sablefish abundance and volume is neither significant $\left(r_{s}=0.240 ; \mathrm{n}=19 ; p=0.321\right)$ nor strong $\left(r_{s}^{2}=0.058\right)$. Among the assemblages collected with $2 \mathrm{~mm}$ mesh, sablefish is poorly

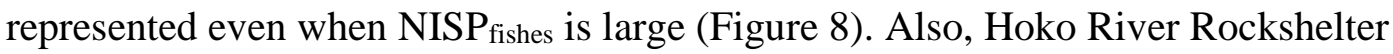
contains few sablefish remains even though it has the largest sample size in terms of NISP, and 100 times more volume than the next largest assemblage (Table 14; Figure 8; Figure 9). However, this could be related to the exclusive use of $6.4 \mathrm{~mm}$ mesh at this site. In sum, sablefish is not scarce because sample sizes are too small. 
Table 14 - Sablefish abundance ("NISP Sable.") and sample size ("NISP Fish" and "Vol. (L)") for Tse-whit-zen and Northwest Coast assemblages.

\begin{tabular}{lcrrr}
\hline \multicolumn{1}{c}{ Assemblage } & $\begin{array}{c}\text { Min. Screen } \\
\text { Size (mm) }\end{array}$ & $\begin{array}{r}\text { NISP } \\
\text { Sable. }\end{array}$ & $\begin{array}{r}\text { NISP } \\
\text { Fish }\end{array}$ & $\begin{array}{c}\text { Vol. } \\
\text { (L) }\end{array}$ \\
\hline Decatur Island - AU 2 & 1.5 & 0 & 2,498 & unk. \\
Decatur Island - AU 5 & 1.5 & 0 & 600 & unk. \\
\hline Daax Haat Kanadaa & 2.0 & 0 & 1,969 & 55 \\
Huu7ii - Back Terrace & 2.0 & 1 & 17,359 & 59 \\
Huu7ii - House 1 & 2.0 & 64 & 15,086 & 122 \\
Tum-tumay-whueton & 2.0 & 0 & 1,813 & 32 \\
Noons Creek & 2.0 & 0 & 1,861 & 257 \\
Kilisnoo Picnicground & 2.0 & 0 & 1,319 & unk. \\
Loon Cave - Comp I & 2.0 & 1 & 8,166 & unk. \\
Loon Cave - Comp II & 2.0 & 0 & 11,183 & unk. \\
\hline 740T & 3.2 & 0 & 121 & 270 \\
Xuud tsixwaas 'llnagaay & 3.2 & 4 & 7,737 & 1,680 \\
Ts'ishaa - Main Village & 3.2 & 22 & 4,785 & 115 \\
Ts'ishaa - Back Terrace & 3.2 & 1 & 1,253 & 33 \\
Tse-whit-zen CZ-7 & 3.2 & 101 & 835 & 120 \\
Tse-whit-zen CZ-6 & 3.2 & 1,284 & 26,206 & 960 \\
Tse-whit-zen CZ-5 & 3.2 & 884 & 6,401 & 690 \\
Tse-whit-zen CZ-4a & 3.2 & 253 & 1,477 & 490 \\
Tse-whit-zen CZ-4b & 3.2 & 108 & 1,070 & 120 \\
Tse-whit-zen CZ-3 & 3.2 & 85 & 634 & 260 \\
Tse-whit-zen CZ-2 & 3.2 & 18 & 270 & 260 \\
Bay Street - 1 & 3.2 & 0 & 410 & 98 \\
Bay Street - 2 & 3.2 & 0 & 227 & 58 \\
Bay Street - 3 & 3.2 & 0 & 253 & 105 \\
Burton Acres & 3.2 & 0 & 5,270 & 462 \\
West Point 428 - Comp 1 & 3.2 & 0 & 2,412 & 870 \\
West Point 428 - Comp 2 & 3.2 & 0 & 1,833 & 690 \\
West Point 429 - Comp 1 & 3.2 & 7 & 552 & 220 \\
West Point 429 - Comp 5 & 3.2 & 0 & 788 & 200 \\
Dionisio Point - Layer A & 3.2 & 0 & 174 & unk. \\
Dionisio Point - Layer B & 3.2 & 2 & 4,882 & unk. \\
Dionisio Point - Layer C & 3.2 & 5 & 7,243 & unk. \\
Duwamish & 3.2 & 0 & 3,999 & unk. \\
English Camp Op A & 3.2 & 0 & 19,581 & unk. \\
English Camp Op D & 3.2 & 0 & 9,124 & unk. \\
\hline Hoko River Rockshelter & 6.4 & & &
\end{tabular}




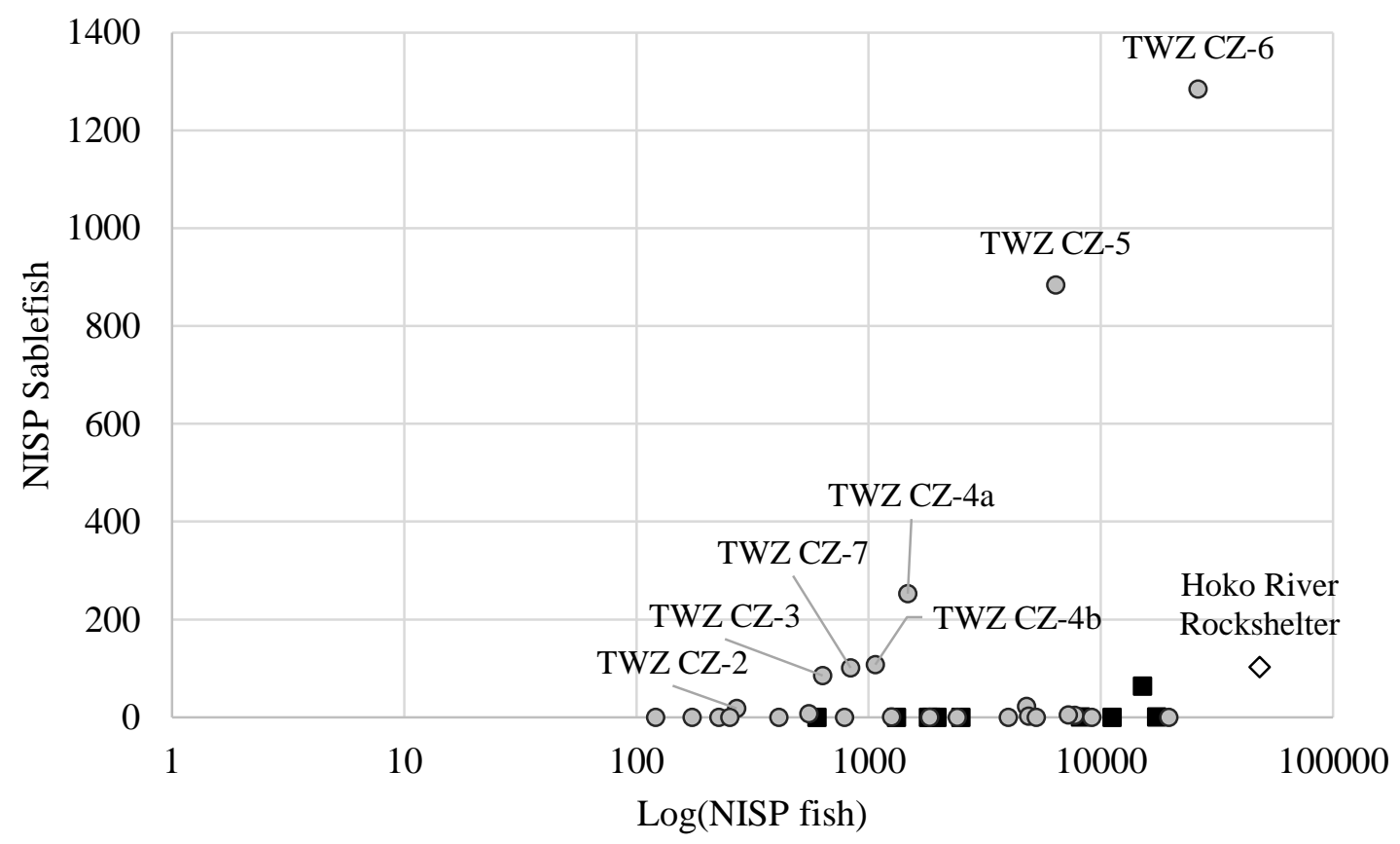

- $2 \mathrm{~mm}$ or Finer Assemblages $\quad 03.2 \mathrm{~mm}$ Assemblages $\diamond 6.4 \mathrm{~mm}$ Assemblage

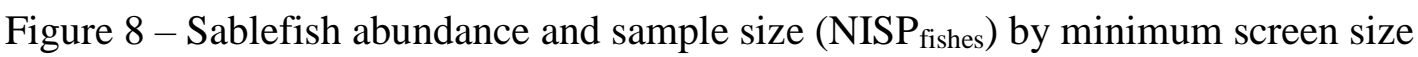
used. ("TWZ" = Tse-whit-zen)

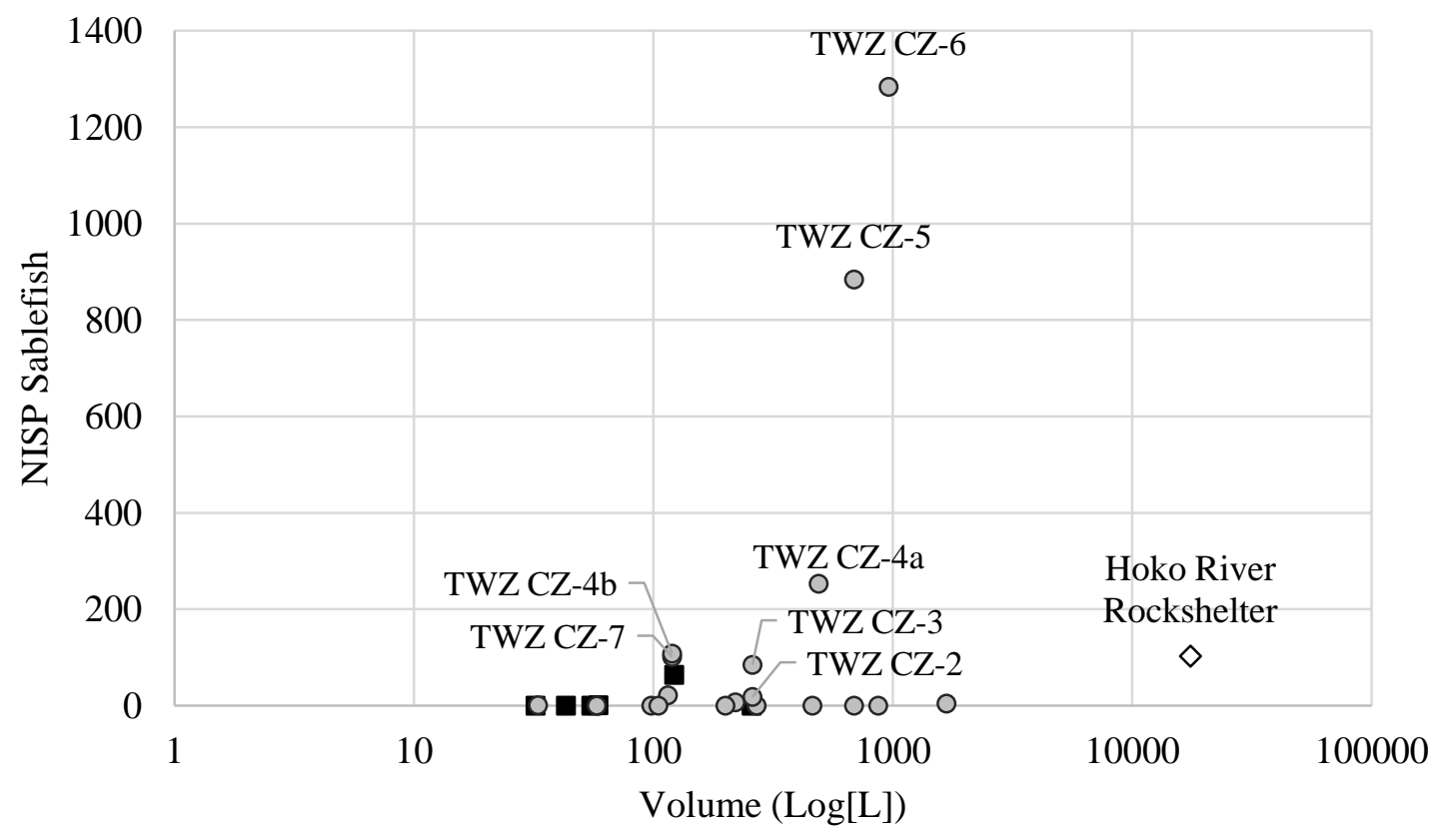

च $2 \mathrm{~mm}$ Assemblages $\quad 03.2 \mathrm{~mm}$ Assemblages $\diamond 6.4 \mathrm{~mm}$ Assemblage

Figure 9 - Sablefish abundance and sample size (volume) by minimum screen size used. ("TWZ" = Tse-whit-zen) 
$\mathrm{H}_{4}$ Results - Sablefish bones are scarce due to post-depositional destruction

To test whether sablefish abundance is related to fragmentation intensity, I compared the relative abundance of sablefish (NISP/L) to the NSP:NISP fishes to see if these two variables are correlated. As I note above, I only compare sablefish abundance and fragmentation intensity for assemblages that were collected with the same mesh size to control for the well-documented effects of screen size on NISP and NSP. If there is a statistically significant relationship, post-depositional destruction must be considered as a possible explanation for the scarcity of sablefish.

Overall, fragmentation intensity is lower in assemblages sampled with a minimum screen size of $2 \mathrm{~mm}$ mesh than in assemblages sampled with coarser mesh (Table 15). Fragmentation intensity in $2 \mathrm{~mm}$ assemblages ranges from a minimum of 1.2 NSP:NISP in the HuuZii Back Terrace assemblage to a maximum of 3.2 NSP:NISP at Tum-tumaywhueton. The minimum fragmentation intensity in $3.2 \mathrm{~mm}$ assemblages is 1.6 NSP:NISP in CZ-6 of Tse-whit-zen, and the maximum is 6.9 NSP:NISP at 740T, which appears to have abnormally high fragmentation for this mesh size on the Northwest Coast (Table 15). However, the average NSP:NISP ratio is relatively similar for $2 \mathrm{~mm}$ assemblages ( $\bar{x}$ $=2.5$ NSP:NISP; $\sigma=0.7)$ and $3.2 \mathrm{~mm}$ assemblages $(\bar{x}=2.9$ NSP:NISP; $\sigma=1.1)$. These observations are quite surprising, considering that smaller mesh sizes are expected to recover many more unidentifiable fragments than coarse mesh, inflating NSP relative to NISP. The high identifiability in the $2 \mathrm{~mm}$ assemblages may indicate that such fine mesh actually recovers far fewer unidentifiable fragments than tiny but identifiable vertebrae of small taxa such as herring (Clupea pallasii) or anchovy (Engraulis mordax). 
Table 15 - Sablefish relative abundance (NISP/L) and fragmentation (NSP:NISP) for Tse-whit-zen and Northwest Coast assemblages. ("Sable" = Sablefish; "Sable. Conc." = Sablefish Concentration)

\begin{tabular}{lcrrrrrc}
\hline \multicolumn{1}{c}{ Site Name } & $\begin{array}{c}\text { Min. Screen } \\
\text { Size (mm) }\end{array}$ & $\begin{array}{c}\text { NISP } \\
\text { Sable. }\end{array}$ & $\begin{array}{c}\text { NISP } \\
\text { Fish }\end{array}$ & $\begin{array}{c}\text { NSP } \\
\text { Fish }\end{array}$ & $\begin{array}{r}\text { Vol. } \\
(\mathbf{L})\end{array}$ & $\begin{array}{c}\text { NSP: } \\
\text { NISP }\end{array}$ & $\begin{array}{c}\text { Sable Conc. } \\
\text { (NISP/L) }\end{array}$ \\
\hline Kilisnoo Picnicground & 2 & 0 & 1,319 & 3,678 & 43 & 2.8 & 0.00 \\
Daax Haat Kanadaa & 2 & 0 & 1,969 & 4,293 & 55 & 2.2 & 0.00 \\
Huu7ii - Back Terrace & 2 & 1 & 17,359 & 21,530 & 59 & 1.2 & 0.02 \\
Huu7ii - House 1 & 2 & 64 & 15,086 & 34,452 & 122 & 2.3 & 0.52 \\
Tum-tumay-whueton & 2 & 0 & 1,813 & 5,822 & 32 & 3.2 & 0.00 \\
Noons Creek & 2 & 0 & 1,861 & 5,853 & 257 & 3.1 & 0.00 \\
\hline 740T & 3.2 & 0 & 121 & 840 & 270 & 6.9 & 0.00 \\
Xuud tsixwaas 'llnagaay & 3.2 & 4 & 7,737 & 20,571 & 1,680 & 2.7 & 0.00 \\
Ts'ishaa - Main Village & 3.2 & 22 & 4,785 & 10,979 & 115 & 2.3 & 0.19 \\
Ts'ishaa - Back Terrace & 3.2 & 1 & 1,253 & 3,289 & 33 & 2.6 & 0.03 \\
TWZ CZ-7 & 3.2 & 101 & 835 & 2,491 & 120 & 3.0 & 0.84 \\
TWZ CZ-6 & 3.2 & 1,284 & 26,206 & 43,128 & 960 & 1.6 & 1.34 \\
TWZ CZ-5 & 3.2 & 884 & 6,401 & 15,022 & 690 & 2.3 & 1.28 \\
TWZ CZ-4a & 3.2 & 253 & 1,477 & 4,001 & 490 & 2.7 & 0.52 \\
TWZ CZ-4b & 3.2 & 108 & 1,070 & 2,951 & 120 & 2.8 & 0.90 \\
TWZ CZ-3 & 3.2 & 85 & 634 & 1,569 & 260 & 2.5 & 0.33 \\
TWZ CZ-2 & 3.2 & 18 & 270 & 673 & 260 & 2.5 & 0.07 \\
Bay Street - Comp 1 & 3.2 & 0 & 410 & 1,635 & 98 & 4.0 & 0.00 \\
Bay Street - Comp 2 & 3.2 & 0 & 227 & 618 & 58 & 2.7 & 0.00 \\
Bay Street - Comp 3 & 3.2 & 0 & 253 & 950 & 105 & 3.8 & 0.00 \\
Burton Acres & 3.2 & 0 & 5,270 & 9,887 & 462 & 1.9 & 0.00 \\
West Point 428 - Comp 1 & 3.2 & 0 & 2,412 & 6,923 & 870 & 2.9 & 0.00 \\
West Point 428 - Comp 2 & 3.2 & 0 & 1,833 & 4,146 & 690 & 2.3 & 0.00 \\
West Point 429 - Comp 1 & 3.2 & 7 & 552 & 1,805 & 220 & 3.3 & 0.03 \\
West Point 429 - Comp 5 & 3.2 & 0 & 788 & 1,686 & 200 & 2.1 & 0.00 \\
\hline Hoko River Rockshelter & 6.4 & 103 & 48,353 & $163,20217,500$ & 3.4 & 0.01 \\
\hline
\end{tabular}

Sablefish concentration is not explained by fragmentation intensity. Sablefish is only represented in assemblages with less than 3.5 NSP:NISP, and it is more concentrated in assemblages that have even lower fragmentation rates (Table 15; Figure 10). However, there are numerous assemblages with fragmentation intensity less than 3.5 NSP:NISP that have few, if any, sablefish remains. The correlation between sablefish concentration and fragmentation in assemblages sampled with a minimum screen size of $3.2 \mathrm{~mm}$ mesh is neither statistically significant $\left(r_{s}=-0.240 ; \mathrm{n}=19 ; p=0.323\right)$ nor strong 
$\left(r_{s}^{2}=0.058\right)$. Fragmentation rates are relatively low among the assemblages sampled with $2 \mathrm{~mm}$ mesh,

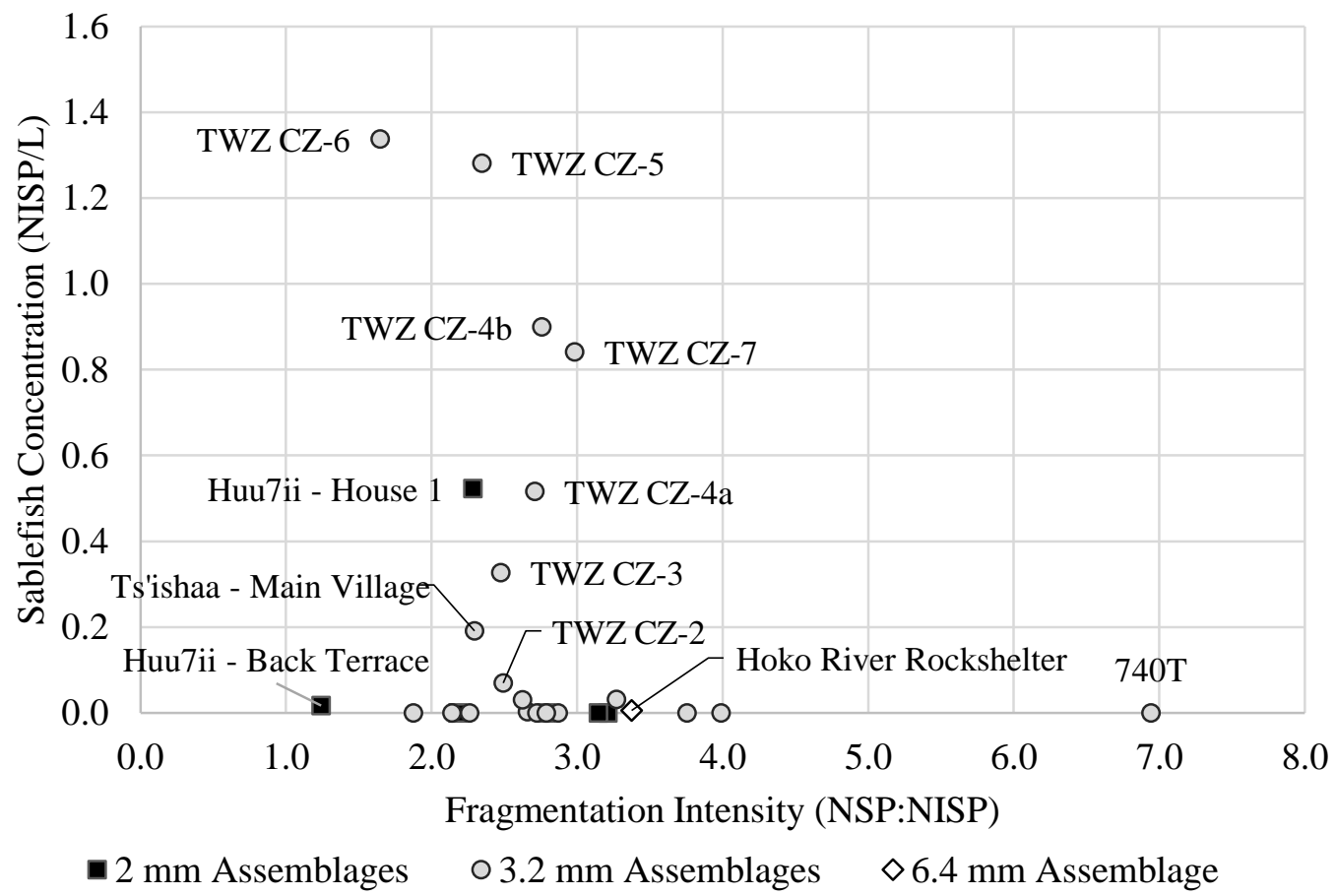

Figure 10 - Sablefish concentration and fragmentation intensity by minimum screen size used. ("TWZ" = Tse-whit-zen)

but sablefish is only present at Huuiii, where it is more abundant in the assemblage that shows greater fragmentation (Huu7ii - House 1; Figure 10).

Focusing on the seven Tse-whit-zen components, there is no relationship between fragmentation and sablefish concentration over the 1,800-year history of Area A4. NSP:NISP fishes ratios for Tse-whit-zen range from a minimum of 1.6 NSP:NISP in CZ-6 to a maximum of 3.0 NSP:NISP in CZ-7 (Table 15; Figure 10), and the average fragmentation intensity is closer to the maximum value ( $\bar{x}=2.5$ NSP:NISP; $\sigma=0.4)$. However, there are no temporal trends in fragmentation intensity. Over the same period, 
sablefish concentration increases through time from a minimum of $0.07 \mathrm{NISP} / \mathrm{L}$ in $\mathrm{CZ}-2$ to 1.34 NISP/L in CZ-6, and then drops back to 0.84 NISP/L in CZ-7 (Table 15; Figure 10). Sablefish is therefore relatively abundant in the components of Tse-whit-zen that have the maximum fragmentation intensity and the minimum fragmentation intensity. While fragmentation is relatively low at Tse-whit-zen relative to other Northwest Coast assemblages, the low post-depositional destruction does not explain the high abundance of sablefish at this site.

Overall, fragmentation appears to affect sablefish representation, and the species is only represented in sites with low fragmentation. However, sablefish relative abundance in Northwest Coast assemblages cannot be explained by fragmentation intensity alone. 


\section{Chapter 5: Discussion and Conclusions}

Sablefish remains are scarce throughout Northwest Coast archaeological assemblages, except at Tse-whit-zen where the remains of this species are abundant. This uneven distribution of sablefish remains could reveal much about the ecological and cultural significance of the species in the region, but previous work has not established whether inter-assemblage comparisons are valid for the Northwest Coast. In addition to cultural and ecological factors, sablefish scarcity could also be related to zooarchaeological methods, archaeological sampling practices, or post-depositional destruction. The primary goals of this thesis were to examine the factors that affect the abundance of sablefish remains in Northwest Coast archaeological sites, and to assess the quality of zooarchaeological data from the region. Based on the results of my hypothesis tests, the scarcity of sablefish is not a result of misidentification $\left(\mathrm{H}_{1}\right)$, of sampling fishbone assemblages with coarse mesh $\left(\mathrm{H}_{2}\right)$, or of identifying small samples of fishbone $\left(\mathrm{H}_{3}\right)$. Similarly, low relative abundances of sablefish cannot be explained by postdepositional destruction, even though sablefish remains may not survive in assemblages that have intense fragmentation $\left(\mathrm{H}_{4}\right)$.

To test whether criteria for sablefish are invalid or nonexistent, I reanalyzed the vertebrae of select taxa in samples of six previously analyzed assemblages $\left(\mathrm{H}_{1}\right)$. My results show that identification criteria for sablefish are valid in these assemblages, insofar as I was able to reproduce the original counts of sablefish vertebrae. Assuming the zooarchaeologists who analyzed these assemblages use the same identification criteria for all assemblages they identify from Northwest Coast middens, sablefish 
identifications, or the absence thereof, may be valid for other fish bone assemblages that were analyzed by the same researchers.

Sablefish scarcity does not appear to be related to invalid identification criteria, but more assemblages will have to be verified before this conclusion can be reached with certainty. Hoko River Rockshelter would be particularly interesting to reexamine as sablefish is unusually abundant in the $6.4 \mathrm{~mm}$ sample from this site. In future studies, I would also attempt to reanalyze fishbone assemblages from Haida Gwaii, where Blackman (1990:244) and Hobler (1978) suggest sablefish was highly valued, and from southeast Alaska in the vicinity of St. John Baptist Bay where the abundance of juvenile sablefish has been highlighted (Echave et al. 2013; Rutecki and Varosi 1997a). Reanalysis projects that include a broader range of taxa and elements could also help verify the validity of inter-assemblage comparisons on the Northwest Coast and establish whether identification criteria and the elements selected for analysis are consistent between assemblages. Where methodological differences do exist, I would explore how those differences actually impact zooarchaeological measures of taxonomic abundance. In the future, zooarchaeologists could also streamline the process of reporting the analytic methods and identification criteria they use by creating an online database for publishing such information.

Because mesh sizes recover remains from taxa with different body sizes unequally (Casteel 1972; James 1997; Lyman 2008:154-156), I attempted to determine empirically which screen sizes are suitably fine to recover sablefish $\left(\mathrm{H}_{2}\right)$. Northwest Coast archaeologists have widely adopted nested screens, which should allow for comparisons of assemblages that were collected with different minimum screen sizes 
(Partlow 2006:75). However, results for the quantities of fishbone recovered in individual screen size fractions are only reported for two (Duwamish and Ts'ishaa) of the 20 sites in my regional fishbone data synthesis that were sampled with nested screens. This is not a problem for the majority of the assemblages, which have a minimum screen size of 3.2 $\mathrm{mm}$, but the few assemblages that have been sampled with $2 \mathrm{~mm}, 1.5 \mathrm{~mm}$, or $1 \mathrm{~mm}$ mesh are more difficult to compare with other collections.

Overall, $3.2 \mathrm{~mm}$ mesh is sufficiently fine to recover sablefish, and the scarcity of sablefish cannot be explained by the screen sizes archaeologists use on the Northwest Coast. Nested screen size data from Tse-whit-zen, Ts'ishaa, and West Point (which I derived from an unpublished database) show that $3.2 \mathrm{~mm}$ mesh is sufficient to recover sablefish remains. While no sablefish are reported in the $1.5 \mathrm{~mm}\left(1 / 16^{\prime \prime}\right)$ sample of Ts'ishaa (McKechnie 2005:Table 8, 35), and I verified that sablefish is not present in the $1.5 \mathrm{~mm}$ fraction of Decatur Island, small sablefish vertebrae were also abundant in a sample of fishbone finer than $3.2 \mathrm{~mm}$ from Tse-whit-zen. These differences suggest the smallest-bodied sablefish may not always be recovered in $3.2 \mathrm{~mm}$ mesh, but sites screened with finer than $3.2 \mathrm{~mm}$ mesh are no more likely to contain sablefish than assemblages that were screened with a minimum mesh size of $3.2 \mathrm{~mm}$. To ensure that small-bodied sablefish have not been overlooked in Northwest Coast assemblages, I would screen unanalyzed bulk samples from previously analyzed assemblages through nested screens with a minimum mesh size finer than $3.2 \mathrm{~mm}$ mesh.

Because the size of an archaeofaunal sample influences the number of taxa represented and their relative abundance, I compared the abundance of sablefish to the sample size of the assemblages in my regional fish bone synthesis using Spearman's rank 
order correlation test with the regression approach $\left(\mathrm{H}_{3}\right)$. My results show that sablefish abundance and sample size are not related. In general, larger assemblages from the Northwest Coast contain no more sablefish than smaller assemblages. The Tse-whit-zen assemblages are exceptional in terms of sablefish representation, as they contain many, many more sablefish remains than other, comparably sized assemblages.

Even though sample size and sablefish abundance are not related, analysts should control for differences in sample size when comparing sablefish remains from Northwest Coast assemblages. This could be accomplished by rarefying taxonomic abundance data using free rarefication software such as Colwell's (2013) EstimateS. In addition, I would assess the sample size of each assemblage to determine whether the relative abundances of the common taxa in the identified assemblage are representative of the deposited assemblage using cumulative frequency curves, mimicking a sampling to redundancy protocol (Lepofsky and Lertzman 2005; Lyman 2008:144-145; Lyman and Ames 2004, 2007). If the cumulative frequency curve of an assemblage levels off when taxonomic abundance data for the most common taxa are added for each excavation level or bucket (in random order or in the order they were excavated), the identified assemblage would be considered representative of the deposited assemblage, and the observed abundance of sablefish would be as well.

Given the relative fragility of sablefish skeletal elements, I attempted to evaluate the effects of post-depositional changes to fishbone assemblages on sablefish abundance by comparing relative sablefish abundance to the fragmentation index NSP:NISP fishes $_{\text {. }}$ while controlling for mesh size $\left(\mathrm{H}_{4}\right)$. I found that fragmentation and relative sablefish abundance are not related. Sablefish is only present in assemblages with low 
fragmentation rates, but there are numerous sites with low fragmentation that lack sablefish. This suggests sablefish are absent from these sites for other reasons.

However, I suspect that fragmentation measures such as NSP:NISP are highly sensitive to differences in the elements that are recorded and the identification criteria used during analysis. For example, I excluded the Cove Cliff and Cama Beach assemblages from this hypothesis test because only a select number of elements were analyzed. In both of these assemblages, NISP is underestimated relative to other assemblages that have all vertebral specimens identified. Consequently, the

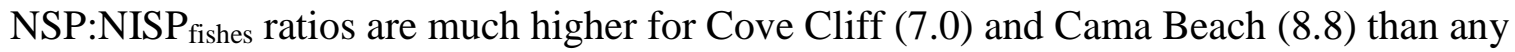
other assemblage in the regional synthesis (maximum $=6.9$ at $740 \mathrm{~T})$. If Trost $(2005$, 2010) did not report these details about the identification criteria and elements analyzed for these two assemblages, I would have reached the invalid conclusion that the high fragmentation rates indicate intense post-depositional destruction at both sites. Fragmentation intensity may actually be high in these assemblages, but because NSP:NISP is so sensitive to the identification procedures, it should only be used to compare assemblages that were analyzed with the same methods.

Taphonomy and post-depositional destruction are critical factors that greatly affect the patterns we observe in assemblages of animal remains, and we require robust tools to discuss their effects on archaeological assemblages. Any fragmentation index that is derived from measurements of taxonomic abundance (i.e. NSP:NISP, NISP:MNI, or NISP:MNE) may reflect the analyst's skill, experience, and identification criteria more than it reflects the fragmentation of animal bone, and is therefore not an adequate tool for large comparative data syntheses. 
Instead, I recommend that zooarchaeologists use fragmentation measures that are not directly related to taxonomic abundance, such as average specimen size (Cannon 2013). As I note above, comparisons of average specimen size can be greatly affected by the taxa and the elements that are present in each assemblage, and by the body-size of the individuals that are represented. The first problem can be controlled for by only comparing specimens that are attributed to the same taxon and skeletal element. If the assemblages being compared are similar in terms of the taxa and elements that are represented, then average size for all identified and unidentified specimens could provide a valid basis of comparison for fragmentation in the assemblages overall. The problem of different body-sizes can be controlled for by also comparing the dimensions of complete anatomical landmarks that scale with body-size. For example, if the average height of the vertebral centrum for sablefish specimens is the same in two assemblages, then average specimen area would provide a valid measure of the differences in fragmentation of sablefish vertebrae that is not influenced by the body-size of the individual fishes.

Though average specimen size can be quickly measured with free image analysis software such as ImageJ (Cannon 2013), a large reanalysis project would be required to generate comparable specimen size measurements for previously analyzed Northwest Coast assemblages. Until this information can be collected, our understanding of the relationship between taxonomic abundance and taphonomic processes for fishes such as sablefish could be improved by measuring the bulk density $\left(\mathrm{g} / \mathrm{cm}^{3}\right)$ of their skeletal elements. Then sablefish abundance could be compared to the relative abundance of other fishes with known bone density values such as salmon and Pacific cod (Gadus 
macrocephalus) to evaluate whether element survivorship and element density are related.

\section{Conclusion}

Sablefish is rarely mentioned in previous archaeological research in the Northwest Coast and the Salish Sea, but its remains are abundant at Tse-whit-zen. To the greatest possible extent, I evaluated and rejected four hypotheses that attribute this pattern of sablefish representation to zooarchaeological methods, sampling strategies, and postdepositional destruction. Therefore, the uneven distribution of sablefish appears to be a true reflection of ecological factors $\left(\mathrm{H}_{5}\right)$ and human decision-making $\left(\mathrm{H}_{6}\right)$. Much more work is required to determine how these two variables affect sablefish representation independently of one another and how they interacted. Body-size regression analysis of sablefish remains can determine the age-at-death of sablefish in the archaeological record, which would connect sablefish capture to specific environmental and seasonal contexts, as body-size is closely linked to season and habitat in the first year of life (Echave et al. 2013; King et al. 2000; Rutecki and Varosi 1997a). Connecting sablefish capture to specific seasons may reveal associations between sablefish acquisition and herring or salmon fisheries.

Data from ancient sablefish remains can also be applied to modern research questions in biological sciences. Zooarchaeological data has the potential to greatly improve our understanding of this species' early life history by providing information about the habitats juveniles prefer at a much broader spatial and temporal scale than modern studies, which are based on 30 years of data from only a few locations (Echave et 
al. 2013; Rutecki and Varosi 1997b). Even nominal-scale information on ancient sablefish presence can contribute to conservation biology by providing historical baseline data about the occurrence of this species in areas it is not currently known to inhabit. For example, only 151 sablefish have been encountered by Washington Department of Fish and Wildlife (WDFW) trawl surveys at 74 sites throughout the Salish Sea since 1987 (Dayv Lowry [WDFW], personal communication 2015), the majority of which were subadults or small adults (James West [WDFW], personal communication 2015). With this in mind, the presence of small-bodied (i.e. possibly juvenile) sablefish at Tse-whit-zen, Ts'ishaa, and West Point (both sites) is very intriguing.

Zooarchaeologists can maximize the value of their contributions to anthropology, biological sciences, and human ecodynamics by explicitly reporting the methods they use to identify animal remains. By reporting the methodological and analytic procedures they used to reach their conclusions in detail, zooarchaeologists enhance the reader's confidence in their conclusions and provide future researchers with the information that is required to replicate their results. Which elements were recorded, and the criteria used to make taxonomic attributions, fundamentally affect the primary faunal data that researchers use to identify spatial and temporal trends in animal resource use, social power and inequality, and site function; reconstruct ecological and environmental conditions, habitats, and foodways; and explore the identities of site occupants. As we begin building large comparative databases to explore large scale patterns (McKechnie et al. 2014; Moss et al. 2015), we have to ensure that zooarchaeological data from multiple assemblages are comparable, and that the patterns we observe are not spurious. With larger datasets and broader goals, the need for rigorous methods increases. 


\section{Works Cited}

Allen, Melinda S.

2003 Human Impact on Pacific Nearshore Marine Ecosystems. In Pacific Archaeology: Assessments and Prospects. Proceedings of the International Conference for the 50th Anniversary of the First Lapita Excavation, Kone, Noumea, 2002, edited by C. Sand, pp. 317-325. Les Cahiers de l'Archaeologie en Nouvelle Caledonie. Vol 15. Service des Musees et du Patromonie de Nouvelle-Caledonie, Noumea.

Arima, Eugene, and John Dewhirst

1990 Nootkans of Vancouver Island. In Handbook of North American Indians, edited by William Sturtevant (General Editor) and Wayne Suttles (Volume Editor), pp. 391-411. U.S. Government Printing Office, Washington, D.C.

Baker, Jonathan Douglas

2009 Prehistoric Bone Grease Production in Wisconsin's Driftless Area: A Review of the Evidence and its Implications. Master's thesis, Department of Anthropology, University of Tennessee, Knoxville.

Baxter, M. J.

2001 Methodological Issues in the Study of Assemblage Diversity. American Antiquity 66(4): 715-725.

Betts, Matthew W., Herbert D. G. Maschner, Corey D. Schou, Robert Schlader, Jonathan Holmes, Nicholas Clement, and Michael Smuin

2011 Virtual Zooarchaeology: Building a Web-Based Reference Collection of Northern Vertebrates for Archaeofaunal Research and Education. Journal of Archaeological Science 38(4): 755-762.

Bird, Douglas W., and James F. O'Connell

2006 Behavioral Ecology and Archaeology. Journal of Archaeological Research 14: 143-188.

Blackman, Margaret B.

1990 Haida: Traditional Culture. In Handbook of North American Indians, edited by William C. Sturtevant (General Editor) and Wayne Suttles (Volume Editor), pp. 240-260. U.S. Government Printing Office, Washington, D.C.

Brewer, Douglas J.

1992 Zooarchaeology: Method, Theory, and Goals. Archaeological Method and Theory 4: 195-244. 
Broughton, Jack M., and James F. O'Connell

1999 On Evolutionary Ecology, Selectionist Archaeology, and Behavioral Archaeology. American Antiquity 64(1): 153-165.

Butler, Virginia L.

1987 Chapter 10: Fish Remains. In The Duwamish No. 1 Site: 1986 Data Recovery. URS Corporation, Seattle, WA.

1996 Tui Chub Taphonomy and the Importance of Marsh Resources in the Western Great Basin of North America. American Antiquity 61(4): 699717.

2004 Fish Remains. In Marmes Rockshelter: A Final Report on 11,000 Years of Cultural Use, edited by Brent A. Hicks, pp. 319-337. Washington State University Press, Pullman, WA.

Butler, Virginia L., and Greg Baker

2002 Appendix 2: Fish Remains from Bay Street Shell Midden (45KP115). In Data Recovery Excavations at the Bay Street Shell Midden (45KP115) Kitsap County, Washington, edited by Dennis E. Lewarch, Leonard A. Forsman, Stepenie K. Kramer, Laura A. Murphy, Lynn L. Larson, David R. Iversen, and Amy E. Dugas. Larson Anthropological/Archaeological Services, Gig Harbor, Washington.

Butler, Virginia L., and Sarah K. Campbell

2004 Resource Intensification and Resource Depression in the Pacific Northwest of North America: A Zooarchaeological Review. Journal of World Prehistory 18(4): 327-405.

Butler, Virginia L., and James C. Chatters

1994 The Role of Bone Density in Structuring Prehistoric Salmon Bone Assemblages. Journal of Archaeological Science 21: 413-424.

Butler, Virginia L., and R. Lee Lyman

1996 Taxonomic Identifications and Faunal Summaries: What Should We Be Including in Our Faunal Reports? Society for American Archaeology Bulletin 14(1): 22.

Butler, Virginia L., and Roy A. Schroeder

1998 Do Digestive Processes Leave Diagnostic Traces on Fish Bones? Journal of Archaeological Science 25(10): 957-971.

Byrd, John E.

1997 The Analysis of Diversity in Archaeological Faunal Assemblages:

Complexity and Subsistence Strategies in the Southeast during the Middle 
Woodland Period. Journal of Anthropological Archaeology 16: 49-72.

Calvert, Sheila Gay

1980 A Cultural Analysis of Faunal Remains from Three Archaeological Sites in Hesquiat Harbour, B.C. Ph.D. dissertation, Department of

Anthropology and Sociology, University of British Columbia.

Campbell, Sarah K., and Virginia L. Butler

2010 Archaeological Evidence for Resilience of Pacific Northwest Salmon Populations and the Socioecological System Over the Last 7,500 Years. Ecology and Society 15(1): 17.

Cannon, Aubrey

1995 The Ratfish and Marine Resource Deficiencies on the Northwest Coast. Canadian Journal of Archaeology 19: 49-60.

2000 Assessing Variability in Northwest Coast Salmon and Herring Fisheries: Bucket-Auger Sampling of Shell Midden Sites on the Central Coast of British Columbia. Journal of Archaeological Science 27(8): 725-737.

Cannon, Michael D.

2013 NISP, Bone Fragmentation, and the Measurement of Taxonomic Abundance. Journal of Archaeological Method and Theory 20(3): 397419.

Casteel, Richard W.

1972 Some Biases in the Recovery of Archaeological Faunal Remains. Proceedings of the Prehistoric Society 38: 382-388.

Collins, Benjamin R.

2010 Element Survivability of Salmo salar. Journal of Taphonomy 8(4): 291300 .

Colwell, Robert K.

2013 EstimateS: Statistical Estimation of Species Richness and Shared Species from Samples. Version 9. User's Guide and application published at: http://purl.oclc.org/estimates.

Coutre, Karson Marie

2014 Feeding Ecology and Movement Patterns of Juvenile Sablefish in Coastal Southeast Alaska. Master's thesis, School of Fisheries and Ocean Sciences, University of Alaska Fairbanks.

Cox, Keith W.

1948 Sablefish Run at Monterey Bay. California Fish and Game 34(1): 37. 
Croes, Dale R.

1988 The Significance of the 3000 B.P. Hoko River Waterlogged Fishing Camp in our Overall Understanding of the Southern Northwest Coast Cultural Evolution. In Wet Site Archaeology, edited by Barbara Purdy, pp. 131152. Telford Press, New Jersey.

2003 Northwest Coast Wet-Site Artifacts: A Key to Understanding Resource Procurement, Storage, Management, and Exchange. In Emerging from the Mist: Studies in Northwest Coast Culture History, edited by R. G. Matson, Gary Coupland, and Mackie Quentin, pp. 51-75. UBC Press, Vancouver, B.C.

2005 The Hoko River Archaeological Site Complex: The Rockshelter (45CA21), 1,000-100 B.P. Washington State University Press, Pullman, WA.

DeLaguna, Frederica

1990a Eyak. In Handbook of North American Indians, edited by William Sturtevant (General Editor) and Wayne Suttles (Volume Editor), pp. 189196. U.S. Government Printing Office, Washington, D.C.

1990b Tlingit. In Handbook of North American Indians, edited by William Sturtevant (General Editor) and Wayne Suttles (Volume Editor), pp. 203228. U.S. Government Printing Office, Washington, D.C.

Driver, Jonathan C.

2011 Identification, Classification and Zooarchaeology. Ethnobiology Letters 2: 19-39.

Echave, K., D. H. Hanselman, and N. E. Maloney

2013 Report to Industry on the Alaska Sablefish Tag Program, 1972-2012. U.S. Department of Commerce, NOAA Technical Memorandum NMFS-

AFSC-254, $47 \mathrm{p}$.

Ewonus, Paul Andrew

2006 The Social Economy of a Northwest Coast Plank House in Perspective. Master's thesis, Department of Anthropology, McMaster Universtiy.

2011 Social Zooarchaeology of a Northwest Coast House. The Journal of Island and Coastal Archaeology 6(1): 72-97.

Gifford, Diane P.

1981 Taphonomy and Paleoecology: A Critical Review of Archaeology's Sister Disciplines. Advances in Archaeological Method and Theory 4: 365-438. 
Gifford-Gonzalez, Diane

2011 Just Methodology?: A Review of Archaeology's Debts to Michael

Schiffer. Journal of Archaeological Method and Theory 18(4): 299-308.

Gobalet, Kenneth W.

2001 A Critique of Faunal Analysis: Inconsistency Among Experts in Blind Tests. Journal of Archaeological Science 28(4): 377-386.

Gordon, Elizabeth A.

1993 Screen Size and Differential Faunal Recovery: A Hawaiian Example. Journal of Field Archaeology 20(4): 453-460.

Grayson, Donald K.

1991 Alpine Faunas from the White Mountains, California: Adaptive Change in the Late Prehistoric Great Basin? Journal of Archaeological Science 18(4): 483-506.

Hajda, Yvonne

1990 Southwestern Coast Salish. In Handbook of North American Indians, edited by William Sturtevant (General Editor) and Wayne Suttles (Volume Editor), pp. 503-517. U.S. Government Printing Office, Washington, D.C.

Hanson, Diane Kay

1991 Late Prehistoric Subsistence in the Strait of Georgia Region of the Northwest Coast. Ph.D. dissertation, Department of Archaeology, Simon Fraser University.

Head, Melissa A., Aimee A. Keller, and Mark Bradburn

2014 Maturity and Growth of Sablefish, (Anoplopoma fimbria), Along the U.S. West Coast. Fisheries Research 159: 56-67.

Hedges, Robert E. M., Andrew R. Millard, and A. W. G. Pike

1995 Measurements and Relationships of Diagenetic Alteration of Bone from Three Archaeological Sites. Journal of Archaeological Science 22(2): 201-209.

Hobler, Philip M.

1978 A Cache of Aboriginal Fishing Gear from the Queen Charlotte Islands. BC Studies 37: 37-47.

James, Steven R.

1997 Methodological Issues Concerning Screen Size Recovery Rates and Their Effects on Archaeofaunal Interpretations. Journal of Archaeological Science 24: 385-397. 
Jans, M. M. E., C. M. Nielsen-Marsh, C. I. Smith, M. J. Collins, and H. Kars

2004 Characterisation of Microbial Attack on Archaeological Bone. Journal of Archaeological Science 31(1): 87-95.

Kennedy, Dorothy I. D., and Randall T. Bouchard

1990 Northern Coast Salish. In Handbook of North American Indians, edited by William Sturtevant (General Editor) and Wayne Suttles (Volume Editor), pp. 441-452. U.S. Government Printing Office, Washington, D.C.

King, J. R., G. A. Mcfarlane, and R. J. Beamish

2000 Decadal-Scale Patterns in the Relative Year Class Success of Sablefish (Anoplopoma fimbria). Fisheries Oceanography 9: 62-70.

Kopperl, Robert E.

2011 Faunal Analysis: Fish. In Is it a House?: Archaeological Excavations at English Camp, San Juan Island, Washington, edited by Amanda K. Taylor and Julie K. Stein, pp. 151-170. Burke Museum of Natural History and Culture, Research Report No. 9, Seattle, WA.

Kopperl, Robert, and Virginia L. Butler

2002 Faunal Analysis: Fish Remains. In Vashon Island Archaeology: A View from Burton Acres Shell Midden, edited by Julie K. Stein and Laura S. Phillips, pp. 105-117. Burke Museum of Natural History and Culture, Research Report No. 8, Seattle, WA.

Lam, Y. M., O. M. Pearson, Curtis W. Marean, and Xingbin Chen

2003 Bone Density Studies in Zooarchaeology. Journal of Archaeological Science 30(12): 1701-1708.

Lambrides, Ariana B. J., and Marshall I. Weisler

2016 Pacific Islands Ichthyoarchaeology: Implications for the Development of Prehistoric Fishing Studies and Global Sustainability. Journal of Archaeological Research.

LaMotta, Vincent M.

2012 Behavioral Archaeology. In Archaeological Theory Today, edited by Ian Hodder, pp. 62-92. Polity Press, Cambridge.

Larson, Lynn L. (editor)

2006 Data Recovery Excavation and Archaeological Monitoring at the Tsewhit-zen Site (45CA523), Clallam County, Washington. Larson Anthropological/Archaeological Services Limited, Gig Harbor, WA. Submitted to Washington State Department of Transportation, Olympic Region, Tumwater, WA. 
Lawrence, Barbara

1973 Problems in the Inter-site Comparison of Faunal Remains. In Domestikationforschung und Geschichte der Haustiere, edited by Janos Matolcsi, pp. 397-402. Akademiai Kiado, Budapest.

Lepofsky, Dana, and Ken Lertzman

2005 More on Richness and Diversity in Archaeobiological Assemblages. Journal of Ethnobiology 25(2): 175-188.

Love, Milton S.

2011 Certainly More Than You Want to Know About the Fishes of the Pacific Coast: A Postmodern Experience. Really Big Press, Santa Barbara.

Lubinski, Patrick M.

1996 Fish Heads, Fish Heads: An Experiment on Differential Bone Preservation in a Salmonid Fish. Journal of Archaeological Science 23(2): 175-181.

Lyman, R. Lee

1985 Bone Frequencies: Differential Transport, In Situ Destruction, and the MGUI. Journal of Archaeological Science 12: 221-236.

1994 What is Taphonomy? In Vertebrate Taphonomy, pp. 1-11. Cambridge University Press, Cambridge.

2008 Quantitative Paleozoology. Cambridge University Press, New York.

Lyman, R. Lee, and Kenneth M. Ames

2004 Sampling to Redundancy in Zooarchaeology: Lessons from the Portland Basin, Northwestern Oregon and Southwestern Washington. Journal of Ethnobiology 24(2): 329-346.

2007 On the Use of Species-Area Curves to Detect the Effects of Sample Size. Journal of Archaeological Science 34(12): 1985-1990.

Marciniak, Arkadiusz

1999 Faunal Materials and Interpretive Archaeology: Epistemology Reconsidered. Journal of Archaeological Method and Theory 6(4): 293320.

Marshall, Fiona, and Tom Pilgram

1993 NISP vs. MNI in Quantification of Body-Part Representation. American Antiquity 58(2): 261-269. 
McFarlane, Gordon A., Mark W. Saunders, Richard E. Thomson, and Ian R. Perry

1997 Distribution and Abundance of Larval Sablefish, Anoplopoma fimbria, Off the West Coast of Vancouver Island, and Linkages to Physical Oceanography. In Biology and Management of Sablefish, Anoplopoma fimbria, edited by Mark E. Wilkins and Mark W. Saunders, pp. 27-38. NOAA Technical Report NMFS 130, Seattle, Washington.

McKechnie, Iain

2005 Five Thousand Years of Fishing at a Shell Midden in the Broken Group Islands, Barkley Sound, British Columbia. Master's thesis, Department of Archaeology, Simon Fraser University.

2012 Zooarchaeological Analysis of the Indigenous Fishery at the Huuzii Big House and Back Terrace, Huu-ay-aht Territory, Southwestern Vancouver Island. In Huu7ii: Household Archaeology at a Nuu-chah-nulth Village Site in Barkley Sound, edited by Alan D. McMillan and Denis E. St. Claire, pp. 154-186. Huu-ay-aht First Nations, Bamfield, BC.

McKechnie, Iain, Dana Lepofsky, Madonna L. Moss, Virginia L. Butler, Trevor J. Orchard, Gary Coupland, Fredrick Foster, Megan Caldwell, and Ken Lertzman

2014 Archaeological Data Provide Alternative Hypotheses on Pacific Herring (Clupea pallasii) Distribution, Abundance, and Variability. Proceedings of the National Academy of Sciences 2014 111(9): 1-10.

McMillan, Alan D., and Denis E. St. Claire

2005 Ts 'ishaa: Archaeology and Ethnography of a Nuu-chah-nulth Origin Site in Barkley Sound. Archaeology Press, Simon Fraser University, Burnaby, B.C.

Medina, Matías E.

2014 Arqueofaunas y procesos de intensificación en el período prehispánico tardío de las Sierras de Córdoba (Argentina): el sitio Arroyo Talainín 2. Comechingonia 18(2): 117-135.

Miller, Bruce S., Charles A. Simenstad, Jeffrey N. Cross, Kurt L. Fresh, and S. Nancy Steinfort

1980 Nearshore Fish and Macroinvertebrate Assemblages Along the Strait of Juan de Fuca Including Food Habits of the Common Nearshore Fish. Marine Ecosystems Analysis, Puget Sound Region, Seattle.

Monks, Gregory G.

1987 Prey as Bait: The Deep Bay Example. Canadian Journal of Archaeology 11: $119-142$. 
Moser, H. Geoffrey, Richard L. Charter, Paul E. Smith, Nancy C.H. Lo, David A.

Ambrose, Cynthia A. Meyer, Elaine M. Sandknop, and William Watson

1994 Early Life History of Sablefish, Anoplopoma Fimbria, Off Washington, Oregon, and California, With Application to Biomass Estimation.

California Cooperative Oceanic Fisheries Investigations Report 35: 144 159.

Moss, Madonna L.

1989 Archaeology and Cultural Ecology of the Prehistoric Angoon Tlingit. Ph.D. dissertation, Department of Anthropology, University of California, Santa Barbara.

2007 The Killisnoo Picnicground Midden (49-SIT-124) Revisited: Assessing Archaeological Recovery of Vertebrate Faunal Remains from Northwest Coast Shell Middens. Journal of Northwest Anthropology 41(1): 1-17.

2010 Rethinking Subsistence in Southeast Alaska: The Potential of Zooarchaeology. Alaska Journal of Anthropology 8(1): 121-136.

2011 Pacific Cod in Southeast Alaska: The "Cousin" of the Fish that Changed the World. In The Archaeology of North Pacific Fisheries, edited by Madonna L. Moss and Aubrey Cannon, pp. 149-169. University of Alaska Press, Fairbanks.

Moss, Madonna L., and Aubrey Cannon

2011 The Archaeology of North Pacific Fisheries: An Introduction. In The Archaeology of North Pacific Fisheries, edited by Madonna L. Moss and Aubrey Cannon, pp. 1-16. University of Alaska Press, Fairbanks, AK.

Moss, Madonna L., Antonia T. Rodrigues, Camilla F. Speller, and Dongya Y. Yang 2015 The Historical Ecology of Pacific Herring: Tracing Alaska Native Use of a Forage Fish. Journal of Archaeological Science Reports(2015).

Nagaoka, Lisa

2002 The Effects of Resource Depression on Foraging Efficiency, Diet Breadth, and Patch Use in Southern New Zealand. Journal of Anthropological Archaeology 21(4): 419-442.

2005 Declining Foraging Efficiency and Moa Carcass Exploitation in Southern New Zealand. Journal of Archaeological Science 32: 1328-1338.

Nicholson, Rebecca A.

1996 Bone Degradation, Burial Medium and Species Representation: Debunking the Myths, an Experiment-based Approach. Journal of 
Archaeological Science 23(4): 513-533.

1998 Bone Degradation in a Compost Heap. Journal of Archaeological Science 25(5): 393-403.

Nielsen-Marsh, Christina M., and Robert E. M. Hedges

2000 Patterns of Diagenesis in Bone I: The Effects of Site Environments.

Journal of Archaeological Science 27(12): 1139-1150.

O'Brien, Matthew

2015 Evaluating the Contemporaneity of Households at the Eden-Farson site. International Journal of Osteoarchaeology 25(5): 653-664.

Orchard, Trevor J.

2007 Otters and Urchins: Continuity and Change in Haida Economy during the Late Holocene and Maritime Fur Trade Periods. Ph.D. dissertation, Department of Anthropology, University of Toronto.

Otaola, Clara

2012 Procesos de intensificacion y aprovechamiento de medula y grasa osea en el sur de Mendoza, Argentina. Archaeofauna 21: 235-247.

Partlow, Megan A.

2006 Sampling Fish Bones: A Consideration of the Importance of Screen Size and Disposal Context in the North Pacific. Arctic Anthropology 43(1): 6779.

Pearson, D. E., and F. R. Shaw

2004 Sources of Age Determination Errors for Sablefish (Anoplopoma fimbria). Fishery Bulletin 102: 127-141.

Pegg, Brian Peter

1999 The Taphonomic History of the Vertebrate Faunal Assemblage from British Camp, San Juan Islands, Washington. Master's thesis, Department of Archaeology, Simon Fraser University.

Pierson, Nova

2011 Bridging Troubled Waters: Zooarchaeology and Marine Conservation on Burrard Inlet, Southwest British Columbia. Master's thesis, Department of Archaeology, Simon Fraser University.

Reetz, Elizabeth C., Dennis E. Lewarch, Stephanie E. Trudel, Nichole Gillis, Hayley E. Kanipe, Sarah L. Sterling, Donald E. Tatum, and Sherry Kekkonen

2006 Chapter 4: Field Techniques. In Data Recovery Excavation and Archaeological Monitoring at the Tse-whit-zen Site (45CA523), Clallam County, Washington, edited by Lynn L. Larson. Volume 1. Report 
submitted to Washington State Department of Transportation, Olympic Region. Larson Anthropological Archaeological Services Limited., Gig Harbor, Washington.

Reitz, Elizabeth J., Irvy R. Quitmyer, and Rochelle A. Marrinan

2009 What Are We Measuring in the Zooarchaeological Record of Prehispanic Fishing Strategies in the Georgia Bight, USA? The Journal of Island and Coastal Archaeology 4(1): 2-36.

Reitz, Elizabeth J., and Elizabeth S. Wing

1999 Zooarchaeology. Cambridge University Press, Cambridge.

Renker, Ann M., and Erna Gunther

1990 Makah. In Handbook of North American Indians, edited by William Sturtevant (General Editor) and Wayne Suttles (Volume Editor), pp. 422430. U.S. Government Printing Office, Washington, D.C.

Rhode, David

1988 Measurement of Archaeological Diversity and the Sample-Size Effect. American Antiquity 53(4): 708-716.

Rosenberg, J. Shoshana

2015 Study of Prestige and Resource Control Using Fish Remains from Cathlapotle, a Plankhouse Village on the Lower Columbia River. Master's thesis, Department of Anthropology, Portland State University.

Rutecki, Thomas L., and Ellen R. Varosi

1997a Distribution, Age, and Growth of Juvenile Sablefish, Anoplopoma fimbria, in Southeast Alaska. In Biology and Management of Sablefish, Anoplopoma fimbria, edited by Mark E. Wilkins and Mark W. Saunders, pp. 45-54. NOAA Technical Report NMFS 130, Seattle, Washington.

1997b Migrations of Juvenile Sablefish, Anoplopoma fimbria, in Southeast Alaska. In Biology and Management of Sablefish, Anoplopoma fimbria, edited by Mark E. Wilkins and Mark W. Saunders, pp. 123-130. NOAA Technical Report NMFS 130, Seattle, Washington.

Schiffer, Michael Brian, and James M. Skibo

1997 The Explanation of Artifact Variability. American Antiquity 62(1): 27-50.

Skibo, James M.

2013 Understanding Pottery Function. In Understanding Pottery Function:

Manuals in Archaeological Method, Theory and Technique, pp. 1-26. Springer, New York. 
Smethurst, Naomi H.

2014 Inscribed on the Landscape: Stories of Stone Traps and Fishing in Laxyuup Gitxaala. Master's thesis, Department of Anthropology, University of British Columbia, Vancouver.

Smith, Ross E., Virginia L. Butler, Shelia Orwoll, and Catherine Wilson-Skogen

2011 Pacific Cod and Salmon Structural Bone Density. In The Archaeology of North Pacific Fisheries, edited by Madonna L. Moss and Aubrey Cannon, pp. 45-56. University of Alaska Press, Fairbanks.

Sogard, Susan M.

2011 Interannual Variability in Growth Rates of Early Juvenile Sablefish and the Role of Environmental Factors. Bulletin of Marine Science 87(4): 857872.

Speth, John D., and Katherine A. Spielmann

1983 Energy Source, Protein Metabolism, and Hunter-Gatherer Subsistence Strategies. Journal of Anthropological Archaeology 2(1): 1-31.

Stevenson, Alexander E., and Virginia L. Butler

2015 The Holocene History of Fish and Fisheries of the Upper Klamath Basin, Oregon. Journal of California and Great Basin Anthropology 35(2): 169188.

Stewart, Hillary

1977 Indian Fishing: Early Methods on the Northwest Coast. Douglas and McIntyre Limited, Vancouver, B.C.

Suttles, Wayne

1990a Environment. In Handbook of North American Indians, edited by William C. Sturtevant (General Editor) and Vol. 7: Northwest Coast edited by Wayne Suttles, pp. 16-29. Washington, D.C.

1990b Handbook of North American Indians. Ed. William C. Sturtevant (General Editor) and Vol. 7: Northwest Coast edited by Wayne Suttles.

Washington, D.C.

Suttles, Wayne, and Barbara Lane

1990 Southern Coast Salish. In Handbook of North American Indians, edited by William Sturtevant (General Editor) and Wayne Suttles (Volume Editor), pp. 485-502. U.S. Government Printing Office, Washington, D.C.

Swanton, John R.

1905 Haida Texts and Myths: Skidegate Dialect. Bureau of Ethnology Bulletin 
29. Washington Government Printing Office.

Trigger, Bruce $\mathrm{G}$.

2006 A History of Archaeological Thought. 2nd ed. Cambridge University Press, New York.

Trost, Teresa

2005 Forgotton Waters: A Zooarchaeological Analysis of the Cove Cliff Site (DhRr 18), Indian Arm, British Columbia. Master's thesis, Department of Archaeology, Simon Fraser University.

2010 Vertebrate Remains. In The Archaeology of Cama Beach Shell Midden (45IS2) Camano Island, Washington, edited by Randall F. Schalk and Margaret A. Nelson, pp. 105-140. Report Submitted to Washington State Parks and Recreation Commission. Cascadia Archaeology, Seattle.

U.S. Department of Agriculture, Agricultural Research Service

2014 USDA National Nutrient Database for Standard Reference, Release 27. In Nutrient Data Laboratory Home Page.

http://www.ars.usda.gov/ba/bhnrc/ndl, accessed February 14, 2015.

Wigen, Rebecca J.

1995 Appendix 5: Fish 45KI428 and 45KI429. In The Archaeology of West Point: 4,000 Years of Hunter-Fisher-Gatherer Land Use in Southern Puget Sound, edited by Lynn L. Larson and Dennis E. Lewarch. Vol. 2. Larson Anthropological/Archaeological Services, Seattle, Washington.

2003 Fish Remains from 45SJ165 and 45SJ169. In Archaeological Investigations at Sites 45SJ165 and 45SJ169, Decatur Island, San Juan County, Washington, edited by Sara L. Walker, pp. 277-308. Eastern Washington University Reports in Archaeology and History 100-118, Cheney, WA.

2005 Vertebrate Fauna. In The Hoko River Archaeological Site Complex: The Rockshelter (45CA21), 1,000-100 B.P., edited by Dale R. Croes, pp. 71104. Washington State University Press, Pullman, WA.

Wolverton, Steve

2002 NISP:MNE and \%Whole in Analysis of Prehistoric Carcass Exploitation. North American Archaeologist 23(2): 85-100.

2013 Data Quality in Zooarchaeological Faunal Identification. Journal of Archaeological Method and Theory 20(3): 381-396.

Wolverton, Steve, Jonathan Dombrosky, and R. Lee Lyman 
2014 Practical Significance: Ordinal Scale Data and Effect Size in Zooarchaeology. International Journal of Osteoarchaeology.

Wolverton, Steve, Lisa Nagaoka, Julie Densmore, and Ben Fullerton

2008 White-Tailed Deer Harvest Pressure \& Within-Bone Nutrient Exploitation During the Mid-to Late Holocene in Southeast Texas. Before Farming 2008(2): 1-23.

Woo, Katherine, Patrick Faulkner, and Anne Ross

2015 The Effects of Sampling on the Analysis of Archeological Molluscan Remains: A Quantitative Approach. Journal of Archaeological Science:

Reports. 
Appendix A: Narrative Descriptions of Synthesized Fishbone Data 
Daax Haat Kanadaa - 49SIT244 (Moss 1989)

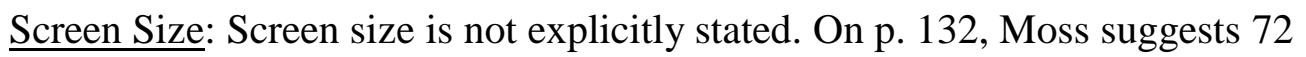
samples were screened in $2 \mathrm{~mm}$ mesh and sorted into material type, with bone put aside for identification. Moss states on p. 141 that 28 column samples were screened, likely into nested 1/4", 1/8" and $2 \mathrm{~mm}$ mesh, and that all 1/4" material was identified, but a quarter of the fine mesh $(1 / 8$ " and $2 \mathrm{~mm})$ material was identified. However, Table 4.5 on p. $142-143$ states that $100 \%$ of the fine mesh sample from 49SIT244 was screened and analyzed. Based on the information in Table 4.5 , I assume the screen size for this site is $\geq$ $2 \mathrm{~mm}$.

NISP and NSP: The abundance of fish remains are reported for 3 separate column samples in Table 5.3, 5.4, and 5.5 on pg. 175, 176, and 177 respectively. All fauna from this site are reported together, without information on screen size samples.

Volume: I estimated volume from data presented in Table 4.1 on page 129 . Three $25 \times 25 \mathrm{~cm}$ columns were excavated to a depth of 20,30 , and $38 \mathrm{~cm}$. I assume they have a square shape, so the volume calculated as $\mathrm{LxWxD}$ is $0.0125 \mathrm{~m} 3(12.5 \mathrm{~L}) ; 0.0188 \mathrm{~m} 3$ $(18.8 \mathrm{~L})$; and $0.0238 \mathrm{~m} 3(23.8 \mathrm{~L})$ respectively, or a total of $55.1 \mathrm{~L}$.

Kilisnoo Picnicground - 49SIT124 (Moss 1989)

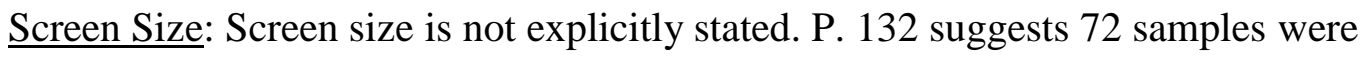
screened in $2 \mathrm{~mm}$ mesh and sorted into material type, with bone put aside for identification. On p. 141, Moss states that 28 column samples were screened with 1/4", $1 / 8$ " and $2 \mathrm{~mm}$ mesh, and suggests that all $1 / 4$ " material and $25 \%$ of the fine mesh $(1 / 8$ " and $2 \mathrm{~mm}$ ) material was identified. However, Table 4.5 on p. 142-143 also states that 
$100 \%$ of the fine mesh sample from column 1 was analyzed, but only $25 \%$ of the fine mesh from column 1 was analyzed. Fauna from this site are reported together, without information on screen size samples. Based on this information, I assume that mesh size for this site is $\geq 2 \mathrm{~mm}$, with the caveat that only $25 \%$ of the $1 / 8$ " and $2 \mathrm{~mm}$ mesh material was analyzed for column 2.

NISP and NSP: Fish abundance is reported for two column samples from this site in Table 6.3 and 6.4 on pages 257 and 258 respectively.

Volume: I estimated volume from data presented in Table 4.1 on page 129. Two elongated columns were excavated into exposed sea cliff. Column 1 was 62.5 x $10 \mathrm{~cm}$ and excavated to $50 \mathrm{~cm}$ depth. Column 2 was 41.6 x $15 \mathrm{~cm}$ and excavated to $40 \mathrm{~cm}$ depth. However, Table 6.3 and Table 4.5 on p. 142 indicate that column 1 was excavated to a depth of $59 \mathrm{~cm}$. I assume that tables 6.3 and 4.5 are correct, and that the depth of column 1 is $59 \mathrm{~cm}$. Volume $=\mathrm{LxWxD}$, so column 1 represents $0.0369 \mathrm{~m} 3(36.9 \mathrm{~L})$ and column 2 represents $0.0250 \mathrm{~m} 3(25.0 \mathrm{~L})$.

Nevertheless, this volume is not representative of the identified assemblage, as only $25 \%$ of the $1 / 8$ " and $2 \mathrm{~mm}$ mesh material was actually analyzed for column 2 , and I do not include this assemblage in any hypothesis test that depends on volume.

\section{Cove Cliff Site - DhRr 18 (Trost 2005)}

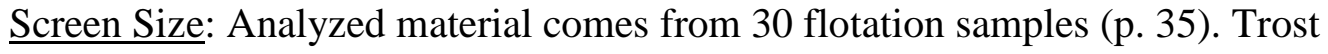
suggests the heavy fraction was passed through nested screens down to $1 \mathrm{~mm}$ mesh. Identified material therefore comes from screens $\geq 1 \mathrm{~mm}$, but the portion from each mesh size is not reported. 
NISP and NSP: Unidentified fish values might be inflated because Osteichthyes vertebrae were only identified if the anterior surface, posterior surface, and a portion of the centrum were present (p. 36-37). Additionally, only a limited range of elements were selected for identification: "articular, basioccipital, dentary, dorsal spines (spiny dogfish only), hyomandibular, palatine, pharyngeal arch (perch, suckerfish only), premaxilla, maxilla, quadrate, scutes, teeth, vertebra, and vomer" (Trost 2005:34). This greatly biases sample size estimates and fragmentation measures.

On p. 40, Trost indicates that the "unidentifiable vertebrate" remains were subsampled by quartering the flotation sample, counting the NSP, and multiplying the result by 4 . However, Appendix B indicates that 17 of the 30 flotation fish samples were subsampled, rather than the unidentified vertebrates. Appendix K reportedly contains information on the standardization of flotation samples based on variable volume and subsampling. However, Appendix $\mathrm{K}$ is not provided with the thesis.

From the description that is provided on p. 40 and in Appendix B, I am uncertain whether fish abundance data reported in Appendix $\mathrm{C}$ is based on raw counts, if it has been multiplied, and what volume the samples actually represent. Given no other information, I use the data in Appendix C on p. 111 to calculate NISP and NSP of fishes.

Because the recording protocols for vertebrae and the elements selected for analysis are unique to this study, and because I am unsure whether the abundances reflect the actual number of specimens that Trost identified, I only include data from this assemblage in nominal scale tests.

Volume: Volumes for each flotation sample are reported in Appendix B on p. 109-110. They are measured in liters and total to $37.95 \mathrm{~L}$. However, the reported volumes 
do not reflect the volume that was actually analyzed, so I do not use this assemblage for any test based on volume.

Hoko River Rockshelter - 45CA21 (Wigen 2005)

Screen Size: On p. 24 Croes (2005) states that excavated material from each level at the site was screened with $1 / 4$ " mesh.

NISP and NSP: Table 4.2 on p. 75-76 reports fish NISP, sablefish NISP, and concentration values for each State (chronological zone), or stratigraphic layer. The number of unidentified fish specimens in State 8 is suspiciously round for such a large assemblage, but there is no suggestion that the count of unidentified specimens was estimated.

Volume: Table 4.10 on p. 86 , provides the volume of material analyzed for each taxon. For fish, $17.50 \mathrm{~m} 3$ of sediment was analyzed.

740T (Orchard 2007)

Screen Size: The assemblage was screened in $1 / 4$ " and $1 / 8$ " mesh, but the data is presented as combined values on p. 229.

NISP and NSP: NISP values are presented in table 7.10 on p. $236-237$. NISP is given as 112, but 19 salmon vertebral fragments were also identified. Including these brings NISP to 121. NSP is also reported in this table.

Volume: Orchard states on p. 229 that faunal materials were identified by Rebecca Wigen. The whole sample was identified, according to Table D.1 on p. 556. Vertebrate remains were collected from the matrix of each level (p. 229). The analyzed 
volume is therefore equal to the volume excavated which is reported in Table 7.2 on p. 189.

7aydi 'Ilnagaay - 717T (Orchard 2007)

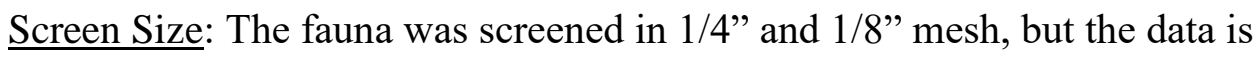
presented as combined values on p. 229.

NISP and NSP: The number of fish taxa identified is given on p. 234 of Table 7.9, p. 232-234. NISP values are presented in table 7.10 on p. 236-237. NISP is given as 6,877 , but 10,522 salmon vertebral fragments were also identified. Including these brings NISP to $17,399$. NSP is also reported in this table.

However, only subsamples were identified and the taxonomic abundances in the subsampled contexts were multiplied to correct for subsampling (p. 229). Because the actual abundance of specimens that were observed are not reported, I only include data from this assemblage in nominal scale tests.

Volume: Vertebrate remains were collected from the matrix of each level (p. 229), but only $25 \%$ of the material was identified from Layers 1c, 2, and 3 at 717 T (Table D.1, p. 556), and NISP was multiplied by 4 (p. 229). It is not possible to estimate the volume of these layers, but the total excavated volume is reported in Table 7.2 on p. 189. Because this is not representative of the analyzed volume, I do not include data from this site in any test that depends on volume.

Kaidsu - 781T (Orchard 2007)

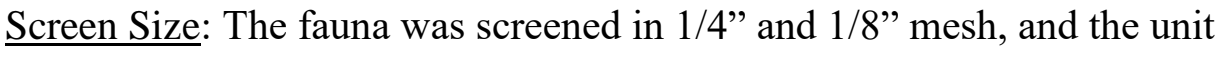


assemblages are reported separately P. 229. However, 1/8" material was only identified from Unit 1.

NISP and NSP: Fish abundance data for Unit 1 only is presented in Table D.11 on p. 572. This reports the $1 / 4$ " and $1 / 8$ " materials together. However, I separated the $1 / 8$ " and $1 / 4$ " mesh results for this unit by subtracting the values for $1 / 8$ " mesh only reported in table 7.10 on p. $236-237$.

Only $25 \%$ of the material was identified from Layers 3 level b and 3 level c, at $781 T$ (Table D.1, p.556), and NISP was multiplied by 4 (p. 229). The data for all levels of layer 3 have been lumped in Table D.11 on p. 572, so it is not possible to determine the actual number of specimens that were identified.

Table D.11 reports 8 sablefish specimens. A ninth specimen is reported for 1/4” mesh in Table 7.10 on p. 236-237, but it comes from Unit 3, according to Table D.13 on p. 576. Therefore, all sablefish in Unit 1 must have derived from 1/8" mesh. Comparing summed NISP from 1/8", Unit 1 only in Table 7.10 to summed NISP from $1 / 8$ " and 1/4" Unit 1 only in Table D.11 shows there is no difference in NISP. Doing the same for unidentified fish shows no differences there either. There could be two possible explanations. Orchard either analyzed only the $1 / 8$ " sample from $781 \mathrm{~T}$ Unit 1 , or the values in Table 7.10 erroneously report the summed 1/4" and 1/8" values from Unit 1 instead of the $1 / 8$ " sample only.

Volume: Vertebrate remains were collected from the matrix of each level (p. 229). The total volume excavated is $1.45 \mathrm{~m}^{3}(1450 \mathrm{~L})$, as stated in Table 7.2 on p. 189 . However, this volume is only representative of the $1 / 4$ " mesh. All identified $1 / 8$ " material appears to have come from Unit 1, layers 2-4, according to Appendix D.11 on p. 572 - 
573. Unit 1 is a $1 \times 1 \mathrm{~m}$ excavation unit, but only the southern half of the unit $(0.5 \times 1 \mathrm{~m})$ was excavated below $26 \mathrm{~cm}$, as stated on p. 466. Dimensions of the unit's volume can be estimated from the stratigraphic profile in Figure B.14 on p.467. The top half of the unit was excavated from 10 to $32 \mathrm{~cm}$ BUD (Below Unit Datum), for a total depth of $22 \mathrm{~cm}$. The volume is therefore $0.22 \mathrm{~m} 3(220 \mathrm{~L})$. The lower half extends from 32 to $\sim 62 \mathrm{~cm}$ BUD, for a total depth of $30 \mathrm{~cm}$. The volume is therefore $0.15 \mathrm{~m}^{3}(150 \mathrm{~L})$. I approximate the total excavated volume represented by the $1 / 8$ " sample as $0.37 \mathrm{~m}^{3}(370 \mathrm{~L})$. Because this is not representative of the analyzed volume, I do not include data from this site in any test that depends on volume.

Note: I use the abundance from 781T, Unit 1 only. Although there is ambiguity related to the screen size, I assume this assemblage was screened with $1 / 4$ " and $1 / 8$ " mesh. Because the actual abundance of specimens that were observed are not reported, I only include data from this assemblage in nominal scale tests.

Qiid 'Ilnagaay - 924T (Orchard 2007)

Screen Size: The fauna was screened in $1 / 4$ " and $1 / 8$ " mesh, but NISP is presented as combined values in table 7.10 on p. 236-237.

NISP and NSP: NISP is given as 16,721 , in table 7.10 on p. $236-237$, but 11,567 salmon vertebral fragments were also identified. Including these brings NISP to 28,288. NSP is also reported in this table. Because the actual abundance of specimens that were observed are not reported, I only include data from this assemblage in nominal scale tests.

Volume: Vertebrate remains were collected from the matrix of each level (p. 229), but only $25 \%$ of the material was identified from Unit 2 Layer 3, and Unit 3 Layer 3 level 
b-e, Layer 4, and Layer 5 level b at 717T (Table D.1, p. 556), and NISP was multiplied by 4 (p. 229). It is not possible to estimate the volume of these layers, but the total excavated volume is reported in Table 7.2 on p. 189. Because this is not representative of the analyzed volume, I do not include data from this site in any test that depends on volume.

Qayjuu 'Ilnagaay - 699T (Orchard 2007)

Screen Size: The fauna was screened in $1 / 4$ " and $1 / 8$ " mesh, but the data is presented as combined values in table 7.10 on p. 236-237.

NISP and NSP: NISP is given as 11,651 in table 7.10 on p. $236-237$, but 18,415 salmon vertebral fragments were also identified. Including these brings NISP to 30,066. NSP is also reported in this table. Because the actual abundance of specimens that were observed are not reported, I only include data from this assemblage in nominal scale tests.

Volume: Vertebrate remains were collected from the matrix of each level (p. 229), but only $25 \%$ of the material was identified from Unit 4 Layer $2 \mathrm{c}$ and d, Level 4; all of Unit 5; and Unit 6 Layer 2 and 3 at 717T (Table D.1, p. 556), and NISP was multiplied by 4 (p. 229). It is not possible to estimate the volume of these layers, but the total excavated volume is reported in Table 7.2 on p. 189. Because this is not representative of the analyzed volume, I do not include data from this site in any test that depends on volume.

Xuud tsixwaas 'Ilnagaay - 785T (Orchard 2007)

Screen Size: The fauna was screened in 1/4" and 1/8" mesh, but the data is 
presented as combined values in table 7.10 on p. $236-237$.

NISP and NSP: NISP is given as 6,317 in table 7.10 on p. $236-237$, but 1,420

salmon vertebral fragments were also identified. Including these brings NISP to 7,737. NSP is also reported in this table.

Volume: Vertebrate remains were collected from the matrix of each level (p. 229), and all materials from $785 \mathrm{~T}$ were analyzed (Table D.1, p. 556). Therefore, the volume estimated is equal to the excavated volume reported in Table 7.2 on p. 189.

\section{English Camp Op A - 45SJ24 (Pegg 1999)}

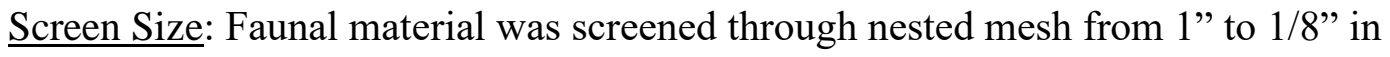
size, p. 18. Not all material was saved for analysis though. $50 \%$ of $1 / 4$ " and $1 / 8$ " specimens were saved from $95-105 \mathrm{~cm}$ depth, $50 \%$ of $1 / 4 "$ and $25 \%$ of $1 / 8$ " specimens were saved from $100-140 \mathrm{~cm}$, and $25 \%$ total was saved from $125-155 \mathrm{~cm}$, according to Table 1.1 on p. 18.

NISP and NSP: On p. 31 Pegg says he did not count the unidentified fish material, so it was not possible to calculate NSP for this site. NISP for each taxon is reported in the text on p. 46-51 with all screen sizes lumped. Without a summary table, I calculated NISP by summing the values given for each taxon.

Volume: Volume estimates can be derived from Appendix A, Table A.1 on p. 114, which presents the volume, depth, and NISP of facies analyzed by Pegg. It is unclear whether the volume for each facie represents the excavated volume, or the volume of material that was actually saved for analysis (p. 18). Also, Facie 3P from unit 304302 is listed as having a volume of $<10 \mathrm{~L}$. I interpret this to mean the facie has a volume of $8 \mathrm{~L}$, 
because the site was excavated with $8 \mathrm{~L}$ buckets.

I obtained a volume estimate of $4.28 \mathrm{~m} 3(4280 \mathrm{~L})$, approximately $6 \%$ of the total site volume $\left(72 \mathrm{~m}^{3}\right)$ from $\mathrm{p} .33$. This does not match Pegg's earlier statement that the analyzed material represents $7 \%$ of the site's volume. It is unlikely that other facies with negligible volume or NISP were excluded, as some included facies contain 0 NISP. However, because this volume is likely not representative of the analyzed volume, I do not include data from this site in any test that depends on volume.

\section{English Camp Op D - 45SJ24 (Kopperl 2011)}

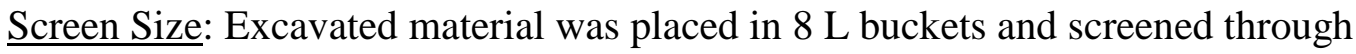
nested 1" to 1/8" mesh (Parr et al. 2011:24).

NISP and NSP: Faunal data reported in this work is based on material before field season 1991, according to Parr et al. (2011) p. 28. NISP information for each taxon and the total fish NSP is presented in Table 12.2 on p. 154. I count 30 fish taxa, and calculate the total NISP by subtracting unidentified fish NSP from total NSP.

Volume: The sampling strategy described by Parr et al. (2011) on p. 25 indicates that all buckets numbered 1-10 were saved, but only buckets with numbers evenly divisible by 4 were saved after bucket \#10. There was approximately a $25 \%$ sample after the first ten buckets were collected. It is not clear from the description whether the bucket sequence is reset for each unit, or each facies, or by any other condition.

Kopperl (2011) analyzed $\sim 25 \%$ of the fish assemblage from $61 \times 2 \mathrm{~m}$ units by selecting every 1st and 4th bucket from a given excavation level and screen size, p. 151. Based on this description, it sounds like there were 9-10 buckets on average for each 
level from the selected units. Selecting 1st and 4th buckets for each screen size is confusing to me, but I assume Kopperl means that all screen sizes for a given bucket number were analyzed.

An estimate of the volume represented by Kopperl's analysis can be derived from Table 12.1 on p. 152-153. The table shows the NISP for each fish family in all six units by facies, and the volume of each facie. It is unclear whether the reported volume is the total volume of the facie, or if it is the volume represented by buckets that were sampled for analysis. I believe the volume estimates likely represent the total volume of the facie, but I have no way to determine the true volume sampled by Kopperl. Because these volumes are likely not representative of the analyzed volume, I do not include data from this site in any test that depends on volume.

Burton Acres - 45KI437 (Kopperl and Butler 2002)

Components: Stein (2002) indicates on p. 56 that the site could be separated into two components, pre and post contact. However, the number of fish bones reported in Table 10.2 by Kopperl and Butler (2002) on p. 111 is so small that separating this site into two assemblages is not useful.

Screen Size: All faunal material was recovered in nested 1" to 1/8" screens as stated on p. 36 by Parr et al. (2002).

NISP and NSP: Summary fish abundance is presented in Table 10.1 on p. 107 by Kopperl and Butler (2002) with all screen sizes lumped. However, unidentified fish are not reported in this table. They are reported in Appendix G for each bucket. To calculate the number of unidentified fish, I created a pivot table in a digital version of the 
Appendix G that I was given access to during my research at the Burke Museum. This file reports that there are 4,617 unidentified fish. Adding these to the NISP reported gives me my total NSP estimate.

I also used the digital version of Appendix G to create a pivot table in Microsoft Excel and separate the fish counts by screen size.

The total NISP reported in Table 10.1 on p. 107 is 5,321, while the value I found in Appendix G is 5,270. I decided to use the Appendix G information over the values from the report, though I cannot account for the differences.

Volume: Table 10.2 on p. 111 shows the volume of material by unit and excavation layer. On p. 112, Kopperl and Butler clarify that the volume in this table represents the volume that was sampled for fish bone analysis.

Decatur Island - 45SJ169 (Wigen 2003)

Components: Five analytic units (AU) have been defined for this site, and they are discussed on p. 79-129 of Walker (2003a), so I present the results of each as a separate assemblage. Only AU 2 and AU 5 are included, however, because the other AUs represent less than 100 NISP each.

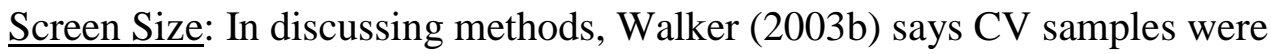
floated and separated with $1 / 4$ " and 1/16" mesh.

NISP and NSP: Summary NISP values are reported with aggregated screen sizes in Table D.7 on p. 283. The Table reports NISP as 3,232, but when I add up the number of NISP for all taxa, I get a value of 3,223, which is the number I use. This table does not 
report the number of unidentified fish in the assemblage, and it is not possible to calculate NSP.

Volume: Nineteen 2 L Constant Volume samples from Analytic Unit 2 were selected for fish bone analysis according to Walker (2003a) on p. 84. For AU3, 8 CVs were sent for analysis, p. 102. One CV from AU 4 was analyzed for fish.

Estimating the volume represented by AU5 materials is more difficult. The excavators recovered fish remains from AU5 in house floor samples, two of which were sent to Wigen for analysis, as stated on p. 113. The material comes from Feature 169-10, which is $20 \mathrm{~cm}$ thick on average, and $3.35 \times 3.2 \mathrm{~m}$ square, or a volume of $2.144 \mathrm{~m}^{3}$, and is part of 18 different excavation units according to the text on p. 116. On p. 119, Walker says "floor Levels" were excavated in 14 of those units. The two samples submitted were 169-HF-13, which includes all housefloor sediment from the SE quarter of unit 5S/8E, and 169-HF-19 includes all housefloor sediment from the southeast quarter of 4S/9E, $p$. 120. From this description, I expect that each sample represents $0.5 \times 0.5 \times 0.2 \mathrm{~m}$ of material, or $0.05 \mathrm{~m}^{3}$.

In contrast with the information Walker (2003b) provided about the number of samples sent for analysis, Appendix D.1 suggests on p. 291-308 that Wigen (2003) analyzed $17 \mathrm{CVs}$ for AU2, $8 \mathrm{CVs}$ for $\mathrm{AU} 3,1 \mathrm{CV}$ for $\mathrm{AU} 4$, and $2 \mathrm{HF}$ samples and $1 \mathrm{CV}$ for AU5. In addition, two catalog numbers are reported without an associated sample number. It is unclear what kind of sample they represent and what volume they might have been derived from.

Wigen (2003) says on p. 227 that she halved all samples with over 500 specimens by volume. Appendix D.1 on p. 291-308 reports which samples were halved by volume. 
However, this information cannot be used to correct the volume estimates to reflect what was identified, because the samples that were split represent only one screen fraction, and the screen size in a given bag is not reported. Furthermore, the 1/4" cannot be differentiated from the $1 / 16$ " mesh fraction from the summary tables, so adjusting the volume would not produce a valid estimate for the $1 / 4$ " samples.

Because of all the issues discussed above, I do not include data from this site in any test that depends on volume.

West Point - 45KI428 and 45KI429 (Wigen 1995)

Components: I was able to record data for the five well-defined components identified at 428 and 429, and these can be analyzed as individual assemblages. However, I exclude Components 3 and 5 of 428 and Components 2 and 3 of 429 because NISP is too low $(57,99,36$, and 32 respectively), and I also exclude Component 4 from both 428 and 429 because nTaxa is too low (4 and 8 taxa respectively).

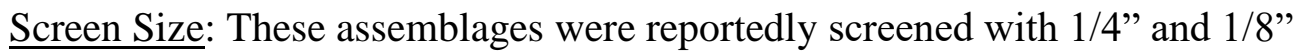
mesh. However, 1/2" mesh was also apparently used based on information in the electronic database discussed below.

NISP and NSP: NISP and the unidentified NSP is reported for individual components and occupations for each area of excavation and site in a number of tables at the end of Appendix 5. However, I simplified the NISP and NSP summing process by using electronic databases of 428 and 429 that I compiled during my reanalysis project at the Burke Museum. Creating pivot tables for these databases in Microsoft Excel also allows me to separate the assemblages into different screen sizes. For this count, I 
excluded all material that did not come from a bulk sample bag.

Volume: Phillips (1995) reports on p. 8 that all bulk sample bags that were selected for sorting and 10 other bags from testing units were sent to Wigen for analysis. Bulk sample bags represent $10 \mathrm{~L}$ samples (p. 8) selected from every 10th bucket (p. 1). According to Phillips (p. 6), there were 1540 1/4" bags and 821 1/8" bags initially selected for sorting, and in a second round of sorting 309 1/4" bags and 154 1/8" bags were added to the sorted material. Therefore, 2,834 bags should have been sent to Wigen for analysis.

While summing NISP and NSP data, I noticed that the number of bags represented in the databases does not match the number of bags that Phillips (1995) reports. Where there should be 2,834 bags total, I count 773 bulk sample bags from 45KI428 and 311 bulk sample bags from 45KI429. Perhaps not all of the bags sent to Wigen were analyzed? Curiously, $1 / 8$ " bags are also better represented for both sites than 1/4" bags, though more $1 / 4$ " bags were reportedly sorted and sent to Wigen.

To estimate the volume that the fish remains recorded in the databases represent, I counted the number of buckets from each site, as well as the number of buckets that had material for each screen size. Each bucket represents $10 \mathrm{~L}$ of bulk matrix that was screened for fish bone in the lab, so the volumes reported in my table represent the number of buckets reported multiplied by 10 L. However, some buckets were analyzed for only $1 / 4$ " or only $1 / 8$ " material.

To overcome this problem, I used the pivot tables to identify which buckets had been completely analyzed by sorting buckets by screen size. Buckets that have material identified in both the $1 / 4$ " and 1/8" fractions were labeled as "C buckets." Any bucket 
missing either $1 / 4$ " or $1 / 8$ " material was labeled as a "CX bucket" and then filtered out of all my analyses. The number of buckets (and consequently volume), NISP (sablefish and total), and NSP I recorded are based on Complete (C) buckets from bulk samples only.

Duwamish - 45KI23 (Butler 1987)

Screen Size: This report includes 1/4" field samples from 1978 and 1986, and a 1986 bulk sample screened in nested 1/4" to $1 / 16$ " mesh (p. 1). I do not include the any of the $1 / 4$ " only results in my table.

NISP and NSP: NISP for each taxon is reported for $1 / 4$ " and $1 / 8$ " bulk sample fractions in Table 10-1 on p. 2 of Butler. The number of unidentified fish is not reported, so it is not possible to calculate NSP.

Volume: From the information in Butler (1987), Kennedy (1987), and Miss (1987), it is not possible to determine the number of bulk samples that were analyzed by Butler, or the volume that any given bulk sample represents. Butler also states on p. 1 that only a small number of $1 / 16$ " samples were sorted and available for analysis, so I will not include this portion in my table.

Bay Street - 45KP115 (Butler and Baker 2002)

Components: Fish bone was sent to Butler from three excavation units, each representing a different chronological component (Lewarch et al. 2002:136). Unit 7 is Comp 1, Unit 2 is Comp 2, and Unit 9 is Comp 3 (p. 51-66). I include results from each component as a separate assemblage.

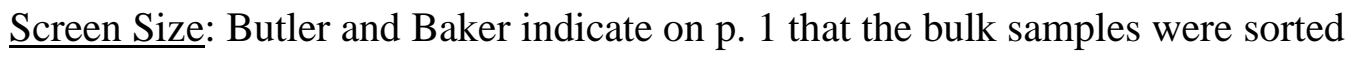


through 1/2", 1/4", and 1/8" mesh. Lewarch et al. (2002) report the volume submitted for analysis of each component on p. 136.

NISP and NSP: NISP for analyzed bulk samples is presented with screen sizes lumped for each component in Tables 4 on p. 11 of Butler and Baker. NSP is reported on Table 2, p. 9 with separate values for each component. I do not use Table 2 to report nested screen values individually because I cannot determine what NISP would be for each screen fraction.

Volume: The analyzed volume is not reported for these assemblages, and I do not include data from this site in any test that depends on volume.

\section{Huu7ii - DfSh 7 (McKechnie 2012)}

Components: Because the deposits from House 1 date to a much later period than the Back Terrace (p. 167), I include these as separate assemblages.

$\underline{\text { Screen Size: }}$ Samples were wet-screened in $1 \mathrm{~mm}$ mesh, and then sieved through $2 \mathrm{~mm}$ mesh, but only $2 \mathrm{~mm}$ vertebrate materials were collected (p. 157). McKechnie states that nested geological sieves were used, but the screen sizes are not reported, and the text suggests vertebrate remains were only collected from $2 \mathrm{~mm}$ screens. Despite this ambiguity, I report the screen size as aggregated nested screens with a minimum mesh size of $2 \mathrm{~mm}$.

NISP and NSP: Table 1 on p. 158 shows the NSP and NISP of all fish, and the total volume of excavated material for each sample. NISP of specific taxa is reported in Table 2 on p. 160. The total fish NISP reported in Table 2 disagrees with the NISP of Table 1, and summing the NISP values in Table 1 produces a number different from both 
total NISP values. My NISP values come from summing the values in Table 1 for the separate assemblages, excluding the privy pit materials.

Volume: Table 2 on p. 158 and the text of p. 161 explains that the total analyzed sample represents $185.4 \mathrm{~L}$ of site deposits from 168 levels.

Loon Cave - DiSo 9 (Calvert 1980)

Components: This site is divided into two assemblages, Component I and Component II.

$\underline{\text { Screen Size: }}$ The deposits for this site were screened through $2 \mathrm{~mm}$ mesh, and all vertebrate remains were collected (p. 124). However, only results from units 1, 2, 3, 8, and 10 are reported.

NISP and NSP: On p. 175, Calvert reports the weight of unidentified fish in Component I, but it appears unidentified specimens were not counted. This is also true for Component II (p. 176). These components are reported separately because there is a gap of several centuries between them according to radiocarbon data referenced on $\mathrm{p}$. 128. NISP for Component I and II are reported separately in Table 45 on p. 298 and Table 49 on p. 302, respectively. When I sum the NISP values for each identified Taxon in Table 49, I get a result of 11,260 , not 10,760 as is reported. I use the result I obtained rather than the value in the table.

Volume: It is not possible to estimate the volume that the identified fish remains represent in either component.

Ts'ishaa - DfSi 16 (McKechnie 2005)

Components: Columns N2-4/W102-104 and S14-16/W25-27 come from the main 
village deposits, while columns S56-57/W50-52 and S62-64/W62-64 come from the back terrace, according to Figure 14 on p. 65. These two areas, (the Main Village and Back Terrace) represent two distinct chronological units, so I treat them as separate assemblages.

$\underline{\text { Screen Size: }}$ Sediments from the site were screened through $6 \mathrm{~mm}$ mesh (p. 29), while faunal remains from column samples were screened through nested sieves from $6 \mathrm{~mm}$ to $1.5 \mathrm{~mm}$ (p. 30). I only report values for the column samples. However, in Table 5 on p. 31 only four columns were actually screened through nested mesh. Table 6 on the same page also indicates that different volumes were analyzed for $>3 \mathrm{~mm}$ and $1.5 \mathrm{~mm}$ samples from the same columns. Because of these differences in sample size, I only recorded the results for the $>3 \mathrm{~mm}$ mesh recovered from the four columns that passed through nested screens. However, I do discuss the $1.5 \mathrm{~mm}$ samples in the text of the thesis.

I report the screen size as $>1 / 8$ " because $3 \mathrm{~mm}$ is comparable to $3.2 \mathrm{~mm}$. Also, in McKechnie (2007), the screen sizes used are $3.2 \mathrm{~mm}$ and $6.4 \mathrm{~mm}$. I assume that all columns were processed with the same screen sizes throughout work at this site, and that the decimal was dropped from the mesh size in the original thesis for stylistic reasons.

NISP and NSP: Table 7 on p. 34 shows NISP for the taxa represented and NSP for individual column samples with lumped screen size samples. Appendix B.3 reports NISP for the $6 \mathrm{~mm}$ mesh sample. To get individual screen size fractions, I use Appendix B. 3 for $6 \mathrm{~mm}$, and subtract Appendix B. 3 values from Table 7 to get the $3 \mathrm{~mm}$ only fraction.

Volume: Volumes for these samples are reported in Table 5 on p. 31. 
Dionisio Point - DgRv 3 (Ewonus 2011)

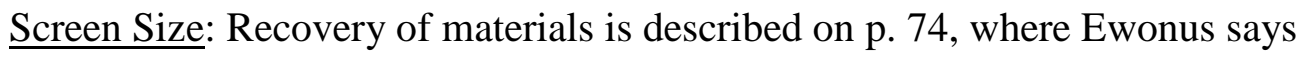
vertebrate material was recovered from excavated sediment passed through $1 / 8$ " mesh. Because the stratigraphic layers from the site are considered different chronological units, I include them as separate assemblages.

NISP and NSP: NISP for each taxon is reported in Table 1 on p. 77-78. I assume that Misc. Osteichthyes refers to unidentified fish, and the total at the bottom of the table is the NSP for all fish.

Volume: On p. 90, fish bone density is discussed in terms of $\mathrm{NISP} / \mathrm{m}^{2}$, but volume excavated or sampled is not reported.

Tum-tumay-whueton - DhRr 6 (Pierson 2011)

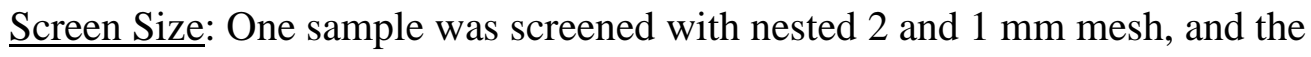
other two with $2 \mathrm{~mm}$ mesh only, p. 18.

NISP and NSP: NISP is lumped for all screen sizes in Table 3-2 on p. 28-29, despite the uneven use of screen sizes across the auger samples. NSP and unidentified counts are not reported. Because of these issues, I measured NSP and NISP using Pierson's supplementary database of zooarchaeological records for this site that is available for download from SFU. I created a pivot table in Microsoft Excel and filtered out fish remains from $1 \mathrm{~mm}$ mesh to get my results.

Volume: Faunal materials come from 3 auger samples (p. 17), but volume was not estimated for this assemblage (p. 18). I approximate it using the diameter of the auger (10 $\mathrm{cm})$ and the depth the samples were taken to $(159 \mathrm{~cm}, 198 \mathrm{~cm}$ reported on p. 13 , the third 
is $54 \mathrm{~cm}$ reported on p. 14). The volume of these should then be $12 \mathrm{~L}, 16 \mathrm{~L}$, and $42 \mathrm{~L}$ respectively.

Noons Creek - DhRq 1 (Pierson 2011)

Screen Size: One sample was screened with nested 2 and $1 \mathrm{~mm}$ mesh, and the other two with $2 \mathrm{~mm}$ mesh, p. 18. One sample was screened with nested 2 and $1 \mathrm{~mm}$ mesh, and the other two with $2 \mathrm{~mm}$ mesh only, p. 18 .

NISP and NSP: NISP is lumped for all screen sizes in Table 3-2 on p. 28-29, despite the uneven use of screen sizes across the auger samples. NSP and unidentified counts are not reported. Because of these issues, I measured NSP and NISP using Pierson's supplementary database of zooarchaeological records for this site that is available for download from SFU. I created a pivot table in Microsoft Excel and filtered out fish remains from $1 \mathrm{~mm}$ mesh to get my results.

Volume: Faunal remains from this site come from three column samples (p. 17). One column was split from a 40x40 cm unit measuring $117 \mathrm{~cm}$ of depth into two column samples, p. 17, so it had a volume of $0.187 \mathrm{~m}^{3}(187 \mathrm{~L})$. The third sample with depth of 87 $\mathrm{cm}$ was also split from a whole unit, but only one part appears to have been analyzed. I assume its dimensions after splitting approximate $20 \times 40 \mathrm{~cm}$, so it would have a volume of $0.070 \mathrm{~m}^{3}(70 \mathrm{~L})$.

Cama Beach - 45IS2 (Trost 2010)

Components: This site has been separated into 5 chronological periods (discussed by Trost on p. 106), but I do not split the site into separate assemblages because it is not 
possible to determine NISP values for sablefish or all fish for individual components from the data that have been reported.

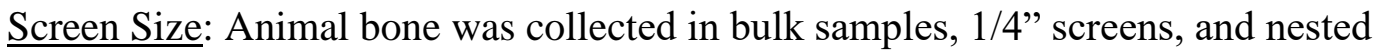
1/4"-1/8" screens according to Nelson et al. (2010) on p. 55 and Table 6.2 on p. 56 . Most bulk samples represent $4 \mathrm{~L}, 1 / 8$ " samples represent $25 \mathrm{~L}$, and the $1 / 4$ " consists of everything that remains. Nelson et al. also explain on p. 56 that the sediment from each level was mixed so that each sample type was collected from a homogenous deposit. Only $1 / 8$ " and $1 / 4$ " samples were used for fish bone analysis, and on p. 105 Trost (2010) explains that any 1/8" sample greater than $25 \mathrm{~L}$ was normalized to $25 \mathrm{~L}$. Some bulk samples were also analyzed for $1 / 4$ "-2mm fractions to explore small fish representation.

NISP and NSP: Only the angular, basioccipital, dentary, elasmobranch spines, hyomanidbular, opercle, palatine, pharyngeal plates, premaxilla, maxilla, quadrate, posttemporal, scutes/denticles, teeth, vertebrae, and vomer were identified, because comparing a subset of fish remains to all identifiable fish remains produces similar results, p. 107. This greatly biases sample size estimates and fragmentation measures. Bags $<1 / 4$ " and $>5.0$ g were subsampled so only $1 / 8,1 / 4$, or $1 / 2$ was analyzed, and then NISP was multiplied to $100 \%$, p. 107. However, Table 9.2c on p. 109 suggests NSP of the $1 / 8$ " fraction from $1 / 8$ " samples were not standardized by subsample or standardized to $25 \mathrm{~L}$ volume. Table 9.5 on p. 112 indicates this also applies to NISP reported for the same portion.

The terms used here are very misleading. The $1 / 8$ " sample represents nested $1 / 8$ " and 1/4" screens collected in $\sim 25 \mathrm{~L}$ batches (see above). This is actually a $>1 / 8$ " sample. I only use the data from this uncorrected $1 / 8$ " sample in my table. 
Sablefish NISP, and total NISP are reported in table 9.5 on p. 112. The NISP for fish does not match in tables 9.5 and 9.2c, which leads me to believe the much higher value in 9.2c has been standardized for subsampling and volume. NSP is reported in Table 9.2c on p. 109.

Because the elements selected for analysis are unique to this study, I only include this assemblage in nominal scale tests.

Volume: Table B.8 of Appendix B on p. B.5 provides the number of fish and volume excavated for each unit in the fishbone analysis. In the text on p. 126, Trost explains that $1 / 8$ " fish samples were only analyzed from Areas A, B, and D. So I estimate volume analyzed using units from these areas only.

However, it is only possible to estimate the volume analyzed by multiplying the number of bags from the $1 / 8$ " sample by the average volume represented by $1 / 8$ " sample bags. On p. 107 while discussing subsampling, Trost mentions there were 126 bags, but it is unclear whether this is the number of $1 / 8$ " samples, or the number of bags containing $<1 / 4$ " and $>1 / 8$ " material. I assume these values would be largely similar, and that the number given is not the total number of bags in the analysis from all sample types. The average volume represented by each 1/8" sample is given by Nelson et al. (2010) in table 6.2 on p. 56 as $23.27 \mathrm{~L}$, with a range of 2.00 to $39.00 \mathrm{~L}$. Using the average value, I estimate the volume analyzed (in 126 bags) as $2930 \mathrm{~L}$.

Because this value has an unknown relationship to the actual volume that was analyzed, I do not include this assemblage in any test that depends on volume. 


\section{Works Cited}

Butler, Virginia L.

1987 Chapter 10: Fish Remains. In The Duwamish No. 1 Site: 1986 Data

Recovery. URS Corporation, Seattle, WA.

Butler, Virginia L., and Greg Baker

2002 Appendix 2: Fish Remains from Bay Street Shell Midden (45KP115). In

Data Recovery Excavations at the Bay Street Shell Midden (45KP115)

Kitsap County, Washington, edited by Dennis E. Lewarch, Leonard A.

Forsman, Stepenie K. Kramer, Laura A. Murphy, Lynn L. Larson, David R. Iversen, and Amy E. Dugas. Larson Anthropological/Archaeological Services, Gig Harbor, Washington.

Calvert, Sheila Gay

1980 A Cultural Analysis of Faunal Remains from Three Archaeological Sites in Hesquiat Harbour, B.C. Ph.D. dissertation, Department of

Anthropology and Sociology, University of British Columbia.

Croes, Dale R.

2005 The Hoko River Archaeological Site Complex: The Rockshelter (45CA21), 1,000-100 B.P. Washington State University Press, Pullman, WA.

Ewonus, Paul Andrew

2011 Social Zooarchaeology of a Northwest Coast House. The Journal of Island and Coastal Archaeology 6(1): 72-97.

Kennedy, Hal

1987 Data Recovery. In The Duwamish No. 1 Site: 1986 Data Recovery, Chapter 3: 1-10. URS Corporation, Seattle, WA.

Kopperl, Robert, and Virginia L. Butler

2002 Faunal Analysis: Fish Remains. In Vashon Island Archaeology: A View from Burton Acres Shell Midden, edited by Julie K. Stein and Laura S. Phillips, pp. 105-117. Burke Museum of Natural History and Culture, Research Report No. 8, Seattle, WA.

Kopperl, Robert E.

2011 Faunal Analysis: Fish. In Is it a House?: Archaeological Excavations at English Camp, San Juan Island, Washington, edited by Amanda K. Taylor and Julie K. Stein, pp. 151-170. Burke Museum of Natural History and Culture, Research Report No. 9, Seattle, WA.

Lewarch, Dennis E., Leonard A. Forsman, Stephenie K. Kramer, Laura R. Murphy, Lynn L. Larson, David R. Iversen, and Amy E. Dugas 
2002 Data Recovery Excavations at the Bay Street Shell Midden (45KP115)

Kitsap County, Washington. Larson Anthropological/Archaeological Services, Gig Harbor, Washington.

McKechnie, Iain

2005 Five Thousand Years of Fishing at a Shell Midden in the Broken Group Islands, Barkley Sound, British Columbia. Master's thesis, Department of Archaeology, Simon Fraser University.

2007 Investigating the Complexities of Sustainable Fishing at a Prehistoric Village on Western Vancouver Island, British Columbia, Canada. Journal for Nature Conservation 15: 208-222.

2012 Zooarchaeological Analysis of the Indigenous Fishery at the Huuzii Big House and Back Terrace, Huu-ay-aht Territory, Southwestern Vancouver Island. In HuuZiii: Household Archaeology at a Nuu-chah-nulth Village Site in Barkley Sound, edited by Alan D. McMillan and Denis E. St. Claire, pp. 154-186. Huu-ay-aht First Nations, Bamfield, BC.

Miss, Christian J.

1987 Laboratory Processing. In The Duwamish No. 1 Site: 1986 Data Recovery, Chapter 3: 10-14. URS Corporation, Seattle, WA.

Moss, Madonna L.

1989 Archaeology and Cultural Ecology of the Prehistoric Angoon Tlingit. $\mathrm{Ph}$.D. dissertation, Department of Anthropology, University of California, Santa Barbara.

Nelson, Margaret, Teresa Trost, and Sarah Thompson

2010 Field and Laboratory Methods. In The Archaeology of Cama Beach Shell Midden (45IS2) Camano Island, Washington, edited by Randall F. Schalk and Margaret A. Nelson, pp. 43-62. Report Submitted to Washington State Parks and Recreation Commission. Cascadia Archaeology, Seattle.

Orchard, Trevor J.

2007 Otters and Urchins: Continuity and Change in Haida Economy during the Late Holocene and Maritime Fur Trade Periods. Ph.D. dissertation, Department of Anthropology, University of Toronto.

Parr, Mary, Laura S. Phillips, and Julie K. Stein

2011 Field Methods. In Is it a House?: Archaeological Excavations at English Camp, San Juan Island, Washington, edited by Amanda K. Taylor and 
Julie K. Stein, pp. 21-28. Burke Museum of Natural History and Culture, Research Report No. 9, Seattle, WA.

Parr, Mary, Julie K. Stein, and Laura S. Phillips

2002 Field and Laboratory Methods and Procedures. In Vashon Island Archaeology: A View from Burton Acres Shell Midden, edited by Julie K. Stein and Laura S. Phillips, pp. 33-45. Burke Museum of Natural History and Culture, Research Report No. 8, Seattle, WA.

Pegg, Brian Peter

1999 The Taphonomic History of the Vertebrate Faunal Assemblage from British Camp, San Juan Islands, Washington. Master's thesis, Department of Archaeology, Simon Fraser University.

Phillips, Laura S.

1995 Chapter 4: Laboratory Processing, Data Entry, and Curation. In The Archaeology of West Point: 4,000 Years of Hunter-Fisher-Gatherer Land Use in Southern Puget Sound, edited by Lynn L. Larson and Dennis E. Lewarch. Vol. 1. Larson Anthropological/Archaeological Services Limited, Gig Harbor, WA. Submitted to Washington State Department of Transportation, Olympic Region, Tumwater, WA, Seattle, WA.

Pierson, Nova

2011 Bridging Troubled Waters: Zooarchaeology and Marine Conservation on Burrard Inlet, Southwest British Columbia. Master's thesis, Department of Archaeology, Simon Fraser University.

Stein, Julie K.

2002 Stratigraphy and Dating. In Vashon Island Archaeology: A View from Burton Acres Shell Midden, edited by Julie K. Stein and Laura S. Phillips, pp. 47-64. Burke Museum of Natural History and Culture, Research Report No. 8, Seattle, WA.

Trost, Teresa

2005 Forgotton Waters: A Zooarchaeological Analysis of the Cove Cliff Site (DhRr 18), Indian Arm, British Columbia. Master's thesis, Department of Archaeology, Simon Fraser University.

2010 Vertebrate Remains. In The Archaeology of Cama Beach Shell Midden (45IS2) Camano Island, Washington, edited by Randall F. Schalk and Margaret A. Nelson, pp. 105-140. Report Submitted to Washington State Parks and Recreation Commission. Cascadia Archaeology, Seattle. 
Walker, Sara L.

2003a Site 45SJ169. In Archaeological Investigations at Sites 45SJ165 and 45SJ169, Decatur Island, San Juan County, Washington, edited by Sara L. Walker, pp. 61-142. Eastern Washington University Reports in Archaeology and History 100-118, Cheney, WA.

2003b Methodology. In Archaeological Investigations at Sites 45 SJ165 and 45SJ169, Decatur Island, San Juan County, Washington, edited by Sara L. Walker, pp. 29-32. Eastern Washington University Reports in Archaeology and History 100-118, Cheney, WA.

Wigen, Rebecca J.

1995 Appendix 5: Fish 45KI428 and 45KI429. In The Archaeology of West Point: 4,000 Years of Hunter-Fisher-Gatherer Land Use in Southern Puget Sound, edited by Lynn L. Larson and Dennis E. Lewarch. Vol. 2. Larson Anthropological/Archaeological Services, Seattle, Washington.

2003 Fish Remains from 45SJ165 and 45SJ169. In Archaeological Investigations at Sites 45SJ165 and 45SJ169, Decatur Island, San Juan County, Washington, edited by Sara L. Walker, pp. 277-308. Eastern Washington University Reports in Archaeology and History 100-118, Cheney, WA.

2005 Vertebrate Fauna. In The Hoko River Archaeological Site Complex: The Rockshelter (45CA21), 1,000-100 B.P., edited by Dale R. Croes, pp. 71104. Washington State University Press, Pullman, WA. 
Appendix B: Buckets Selected for Reanalysis from Burton Acres (45KI437), Decatur

Island (45IS 169), English Camp Op A and Op D (45SJ24), and West Point (45KI428 and 45KI429) 
Table B.1 - Bags selected for reanalysis from previously analyzed assemblages.

\begin{tabular}{|c|c|c|c|}
\hline Site & Unit & Catalog Number & Alternate Designation \\
\hline \multirow[t]{28}{*}{$45-\mathrm{KI}-428$} & B1-10 & B1-1391.07 & \\
\hline & & B1-1391.08 & \\
\hline & B1-15 & B1-1030.04 & \\
\hline & & B1-1030.07 & \\
\hline & B1-17 & B1-1955.08 & \\
\hline & & B1-1955.10 & \\
\hline & B $1-25$ & B1-0759.02 & \\
\hline & & B1-0759.08 & \\
\hline & B $1-5$ & B1-0313.05 & \\
\hline & B2-10 & B2-0534.02 & \\
\hline & & B2-0534.07 & \\
\hline & & B2-0534.10 & \\
\hline & & B2-0534.12 & \\
\hline & B2-12 & B2-0661.04 & \\
\hline & & B2-0661.08 & \\
\hline & & B2-0661.10 & \\
\hline & B2-16 & B2-0575.04 & \\
\hline & & B2-0575.07 & \\
\hline & B2-19 & B2-0145.05 & \\
\hline & B2-27 & B2-2036.04 & \\
\hline & B2-6 & B2-0481.02 & \\
\hline & & B2-0481.11 & \\
\hline & B3-11 & B3-453.03 & \\
\hline & & B3-453.06 & \\
\hline & SB-4 & SB-192.03 & \\
\hline & & SB-192.07 & \\
\hline & SB-5 & SB-143.03 & \\
\hline & & SB-143.07 & \\
\hline \multirow[t]{11}{*}{$45-\mathrm{KI}-429$} & CL2-1 & CL2-068.05 & \\
\hline & & CL2-068.10 & \\
\hline & E1-11 & E1-0208.02 & \\
\hline & & E1-0208.06 & \\
\hline & & E1-0208.07 & \\
\hline & E1-22 & E1-1277.02 & \\
\hline & & E1-1277.05 & \\
\hline & E1-22 & E1-1344.01 & \\
\hline & & E1-1344.02 & \\
\hline & & E1-1344.07 & \\
\hline & E1-27 & E1-1200.03 & \\
\hline
\end{tabular}




\begin{tabular}{|c|c|c|c|}
\hline Site & Unit & Catalog Number & Alternate Designation \\
\hline \multirow[t]{16}{*}{$45-\mathrm{KI}-429$} & E1-4 & E1-1200.07 & \\
\hline & & E1-0193.05 & \\
\hline & E1-5 & E1-0701.07 & \\
\hline & & E1-0717.02 & \\
\hline & & E1-0717.07 & \\
\hline & & E1-0744.04 & \\
\hline & & E1-0744.09 & \\
\hline & & E1-0831.03 & \\
\hline & & E1-0831.06 & \\
\hline & & E1-0831.07 & \\
\hline & NA-11 & NA-305.04 & \\
\hline & NA-8 & NA-445.05 & \\
\hline & & NA-445.10 & \\
\hline & SG-6 & SG-359.08 & \\
\hline & & SG-466.05 & \\
\hline & & SG-466.08 & \\
\hline \multirow[t]{10}{*}{$45-\mathrm{KI}-437$} & $22 / 58$ & 2E.20.24 & \\
\hline & & 2E.20.28 & \\
\hline & $26 / 57$ & 3A.4.24 & \\
\hline & & $3 \mathrm{~A} .4 .28$ & \\
\hline & $28 / 58$ & 2B.32.24 & \\
\hline & & 2B.32.28 & \\
\hline & & 2C. 4.24 & \\
\hline & & 2C.4.28 & \\
\hline & $29 / 58$ & 2D.12.24 & \\
\hline & & 2D. 12.28 & Lot No.; Sample No. \\
\hline \multirow[t]{9}{*}{$45-\mathrm{SJ}-169$} & $2 \mathrm{~S} / 21 \mathrm{E}$ & 1390 & 499; DR-CV-133 \\
\hline & $4 \mathrm{~S} / 9 \mathrm{E}$ & 491 & 120; DR-HF-19 \\
\hline & & 493 & 121; DR-HF-19 \\
\hline & $5 \mathrm{~S} / 7 \mathrm{E}$ & 1452 & 512; DR-CV-14 \\
\hline & & 1445 & 511; DR-CV-14 \\
\hline & $8 \mathrm{~S} / 2 \mathrm{E}$ & 1665 & 547; DR-CV-236 \\
\hline & & 1671 & 548; DR-CV-236 \\
\hline & & 1676 & 549; DR-CV-1676 \\
\hline & & & SAJH No. \\
\hline \multirow[t]{5}{*}{ 45-SJ-24 Op A } & 304300 & $.1 \mathrm{~d} .01 .184 .24$ & 17277 \\
\hline & & $.1 \mathrm{~d} .01 .184 .28$ & 17692 \\
\hline & 304302 & $.1 \mathrm{a} .02 .100 .24$ & 16009 \\
\hline & & $.1 \mathrm{a} .02 .100 .28$ & 16027 \\
\hline & & $.2 \mathrm{v} .01 .001 .24$ & 39125 \\
\hline
\end{tabular}




\begin{tabular}{|c|c|c|c|}
\hline Site & Unit & Catalog Number & Alternate Designation \\
\hline & & & SAJH No. \\
\hline \multirow[t]{19}{*}{ 45-SJ-24 Op A } & 304302 & $.2 \mathrm{v} .01 .001 .28$ & 39138 \\
\hline & & $.2 \mathrm{v} .01 .004 .24$ & 39128 \\
\hline & & $.2 \mathrm{v} .01 .004 .28$ & 39141 \\
\hline & & $.2 \mathrm{v} .01 .005 .24$ & 39129 \\
\hline & & $.2 \mathrm{v} .01 .005 .28$ & 39142 \\
\hline & & $.2 \mathrm{v} .02 .003 .24$ & 93823 \\
\hline & & $.2 \mathrm{v} .02 .003 .28$ & 93844 \\
\hline & & $.2 \mathrm{v} .02 .020 .24$ & 93833 \\
\hline & & $.2 \mathrm{v} .02 .020 .28$ & 93854 \\
\hline & 306302 & $.1 c .01 .162 .24$ & 13719 \\
\hline & & $.1 \mathrm{c} .01 .162 .28$ & 13721 \\
\hline & & $.2 \mathrm{e} .01 .001 .24$ & 10188 \\
\hline & & $.2 \mathrm{e} .01 .001 .28$ & 10189 \\
\hline & & $.4 \mathrm{e} .01 .004 .24$ & 94253 \\
\hline & & $.4 \mathrm{e} .01 .004 .28$ & 94258 \\
\hline & 308302 & $.1 \mathrm{j} .01 .004 .24$ & 23837 \\
\hline & & $.1 \mathrm{j} .01 .004 .28$ & 23854 \\
\hline & & $.1 \mathrm{j} .01 .016 .24$ & 23841 \\
\hline & & $.1 \mathrm{j} .01 .016 .28$ & 23853 \\
\hline \multirow[t]{20}{*}{ 45-SJ-24 Op D } & 105365 & .00 .01 .020 .24 & 127310 \\
\hline & & .00 .01 .020 .28 & 127327 \\
\hline & & $.1 \mathrm{k} .02 .012 .24$ & 103772 \\
\hline & & $.1 \mathrm{k} .02 .012 .28$ & 103783 \\
\hline & & .10 .01 .020 .24 & 103864 \\
\hline & & .10 .01 .020 .28 & 103877 \\
\hline & & $.1 \mathrm{~s} .01 .004 .24$ & 127140 \\
\hline & & $.1 \mathrm{~s} .01 .004 .28$ & 127152 \\
\hline & 107341 & $.1 \mathrm{~d} .01 .001 .24$ & 40661 \\
\hline & & $.1 \mathrm{~d} .01 .001 .28$ & 40663 \\
\hline & 111349 & $.2 \mathrm{a} .01 .001 .24$ & 104103 \\
\hline & & $.2 \mathrm{a} .01 .001 .28$ & 104113 \\
\hline & & $.2 \mathrm{~d} .01 .004 .24$ & 127340 \\
\hline & & $.2 \mathrm{~d} .01 .004 .28$ & 127344 \\
\hline & & $.2 \mathrm{~d} .02 .004 .28$ & 127355 \\
\hline & 121347 & $.1 \mathrm{~d} .02 .012 .24$ & 127523 \\
\hline & & $.1 \mathrm{~d} .02 .012 .28$ & 127536 \\
\hline & & $.1 \mathrm{a} .05 .084 .24$ & 40899 \\
\hline & & $.1 \mathrm{a} .05 .084 .28$ & 40907 \\
\hline & 130352 & $.1 \mathrm{a} .02 .020 .24$ & 105903 \\
\hline
\end{tabular}




\begin{tabular}{llll}
\hline Site & Unit & Catalog Number & Alternate Designation \\
\hline & & & SAJH No. \\
\hline 45-SJ-24 Op D & 130352 & $.1 \mathrm{a} .02 .020 .28$ & 105915 \\
& & $.1 \mathrm{~b} .02 .012 .24$ & 105982 \\
& $.1 \mathrm{~b} .02 .012 .28$ & 105994 \\
& $.1 \mathrm{~b} .03 .004 .24$ & 106020 \\
& $.1 \mathrm{~b} .03 .004 .28$ & 106034 \\
\hline
\end{tabular}


Appendix C: Identification Criteria Used for Reanalysis of Sablefish, Salmonid, Sculpin, and Flatfish Vertebrae 
For my reanalysis, I tallied all vertebral specimens belonging to sablefish (Anoplopoma fimbria), salmon (family Salmonidae), sculpins (family Cottidae), and flatfish (order Pleuronectiformes). The elements I recorded for salmon are vertebra type 1 , vertebra type 2 , vertebra type 3 , vertebra type 4 (types are defined below) and vertebral fragments. Because the woven fenestrated texture on salmonid vertebrae is also found on sablefish vertebrae, and it can also be found in non-vertebral elements, I only consider salmonid vertebral fragments identifiable if they include a distinctive morphological landmark, such as a portion of a vertebral spine, a portion of a dorsal spine facet, or a portion of the robust centrum lip (Figure C.1).

The elements I recorded for non-salmonid taxa are the first vertebra, indeterminate vertebra, and vertebral fragment. Indeterminate vertebrae represent all vertebral specimens not identifiable as the first vertebra that include at least half of the opening for the notochord. Vertebral fragments include all vertebral specimens that include less than half of the opening for the notochord. I do not record abdominal, precaudal, and caudal vertebrae as separate elements because it is often impossible to determine whether the haemal arch - the distinctive feature of caudal vertebrae - is present or absent due to breakage of the haemal processes. Furthermore, the distinction between abdominal vertebrae and pre-caudal vertebrae is defined by the presence of a transverse process, which may be arbitrarily defined. Nevertheless, I report the distinguishing features of abdominal, pre-caudal, and caudal vertebrae for the three nonsalmonid taxonomic groups below.

Vertebrae for many sculpin species are easily distinguished from sablefish vertebrae by bone texture alone. Sablefish vertebrae are always finely fenestrated with a 
woven texture, but a similar texture is usually only found in family Cottidae on the vertebrae of staghorn sculpins (Leptocottus armatus). Vertebrae from other sculpin taxa are not likely to be confused for sablefish. Cabezon (Scorpaenichthys marmoratus) and Irish lords (Hemilepidotus sp.) have vertebrae with a solid, glossy texture. Buffalo sculpin (Enophrys bison) vertebrae have distinctive, scooped lateral sides. And great sculpin (Myoxocephalus polyacanthocephalus) vertebrae have a large, distinctive foramen on the ventral side of the centrum. However, it is possible that sablefish vertebrae might be identified as an indeterminate sculpin on the basis of some morphological similarities, and I attempt to distinguish sablefish vertebrae from the general features of sculpin vertebrae below.

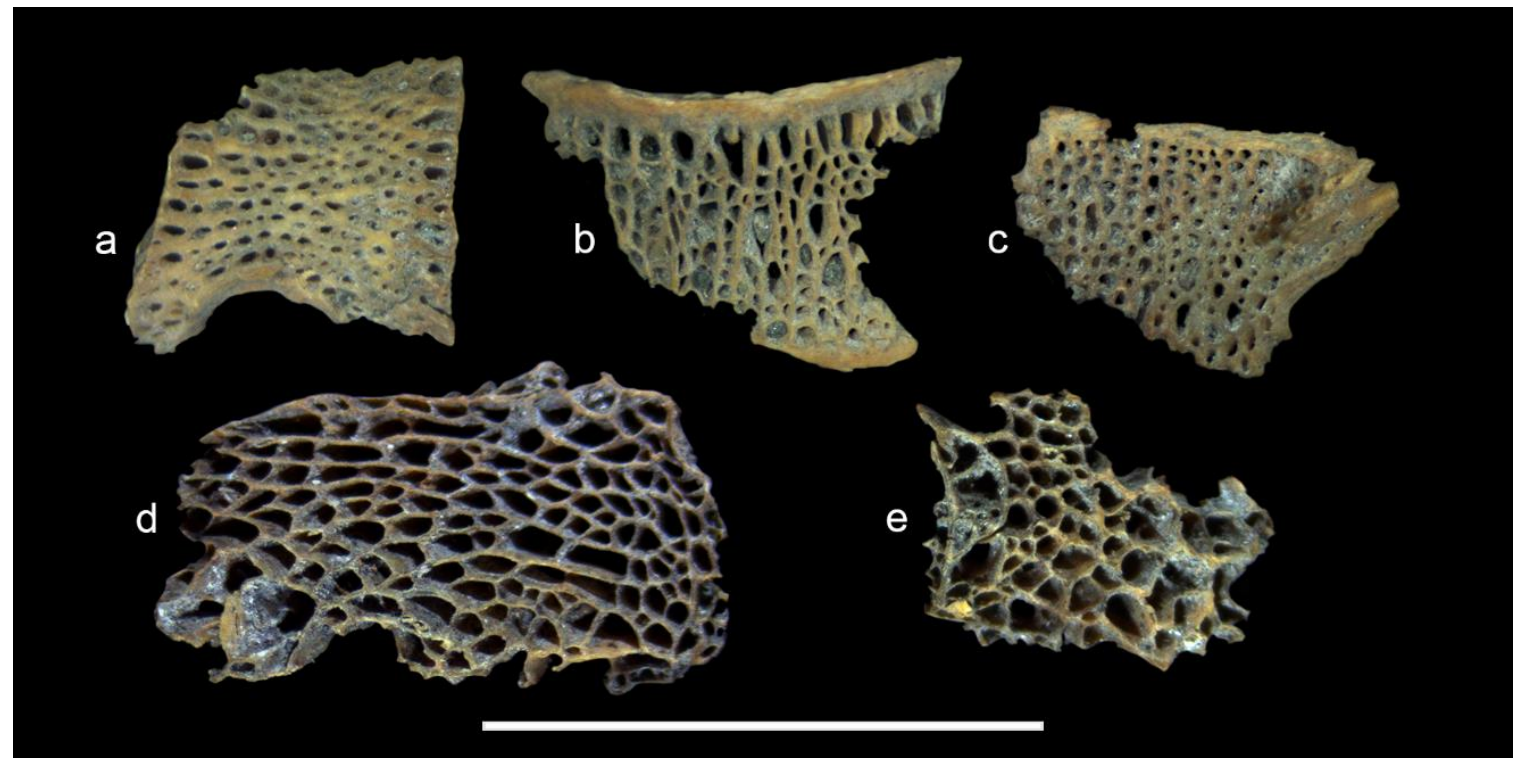

Figure C.1 - Identifiable salmon vertebral fragments (top row) and unidentified fish bone specimens (bottom row). Salmonid fragments identified by a) vertebral spine facet, $b$ ) robust lip, and c) base of vertebral spine. Scale bar is $10 \mathrm{~mm}$ long. Photos by Tony Hofkamp. (Courtesy of the Thomas Burke Memorial Washington State Museum, catalog number WS-14677.99.08.23, Area A4, Unit 17) 


\section{First Vertebra/Vertebra Type 1}

The first vertebrae of sablefish, sculpins, and flatfish, and salmon vertebra type 1 , are all easily distinguished by the exoccipital facets on the rostral side of the vertebra, and the shape of the centrum.

Sablefish first vertebrae have ovoid facets on the dorsolateral sides of a semicircular centrum (Figure C.2a).

Sculpin first vertebrae have small exoccipital facets on the rostral ends of prominent prezygapophyses (Figure C.2b) and a semi-rectangular centrum (Figure C.3b).

The salmonid vertebra type 1 has large, rugose exoccipital facets that overlay the centrum (Figure C.2c).

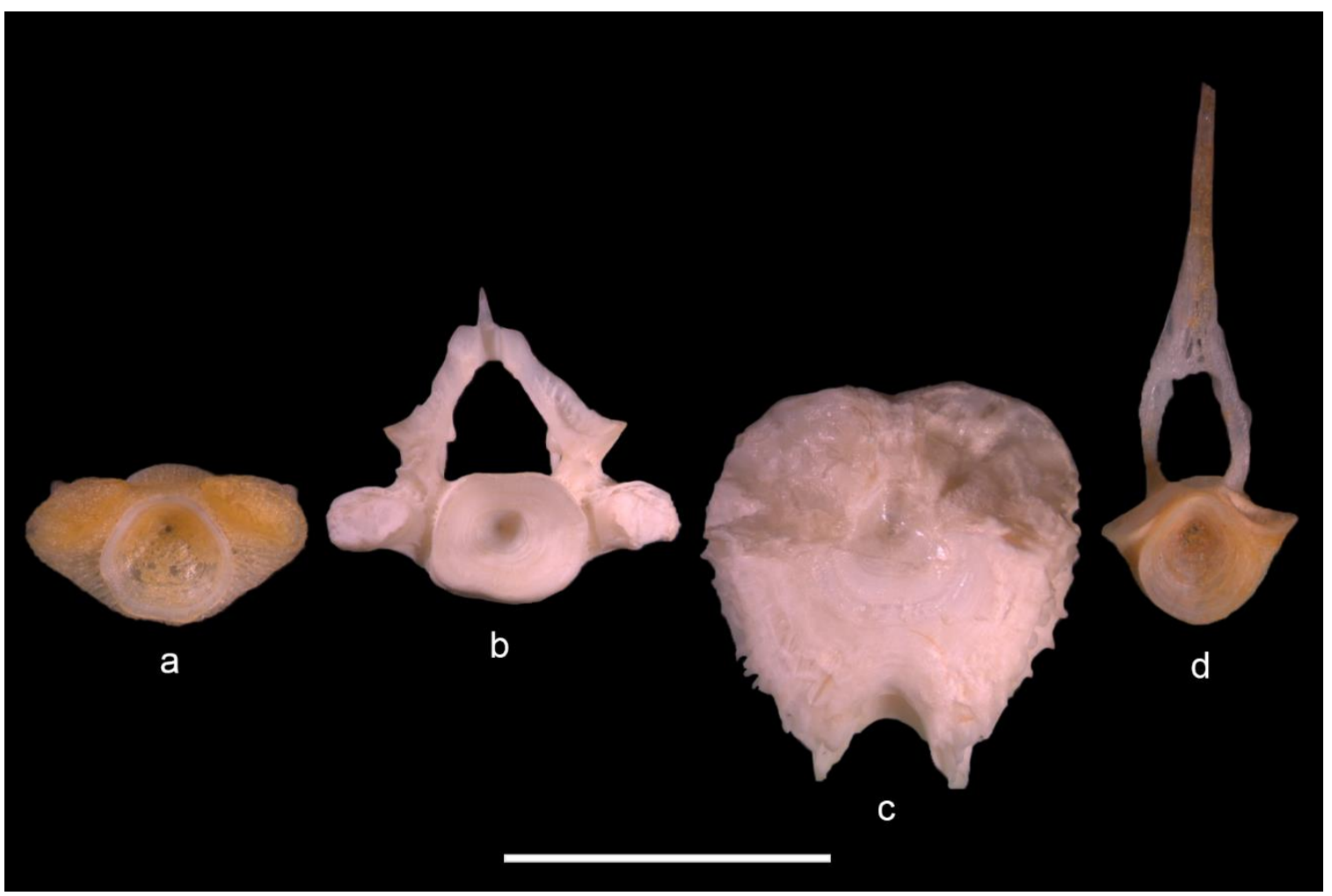

Figure C.2 - Rostral side of first vertebrae from a) sablefish (Anoplopoma fimbria), b) staghorn sculpin (Leptocottus armatus), c) salmon (Oncorhynchus kisutch), and e) rex sole (Glyptocephalus zachirus). Scale bar is $10 \mathrm{~mm}$ long. 


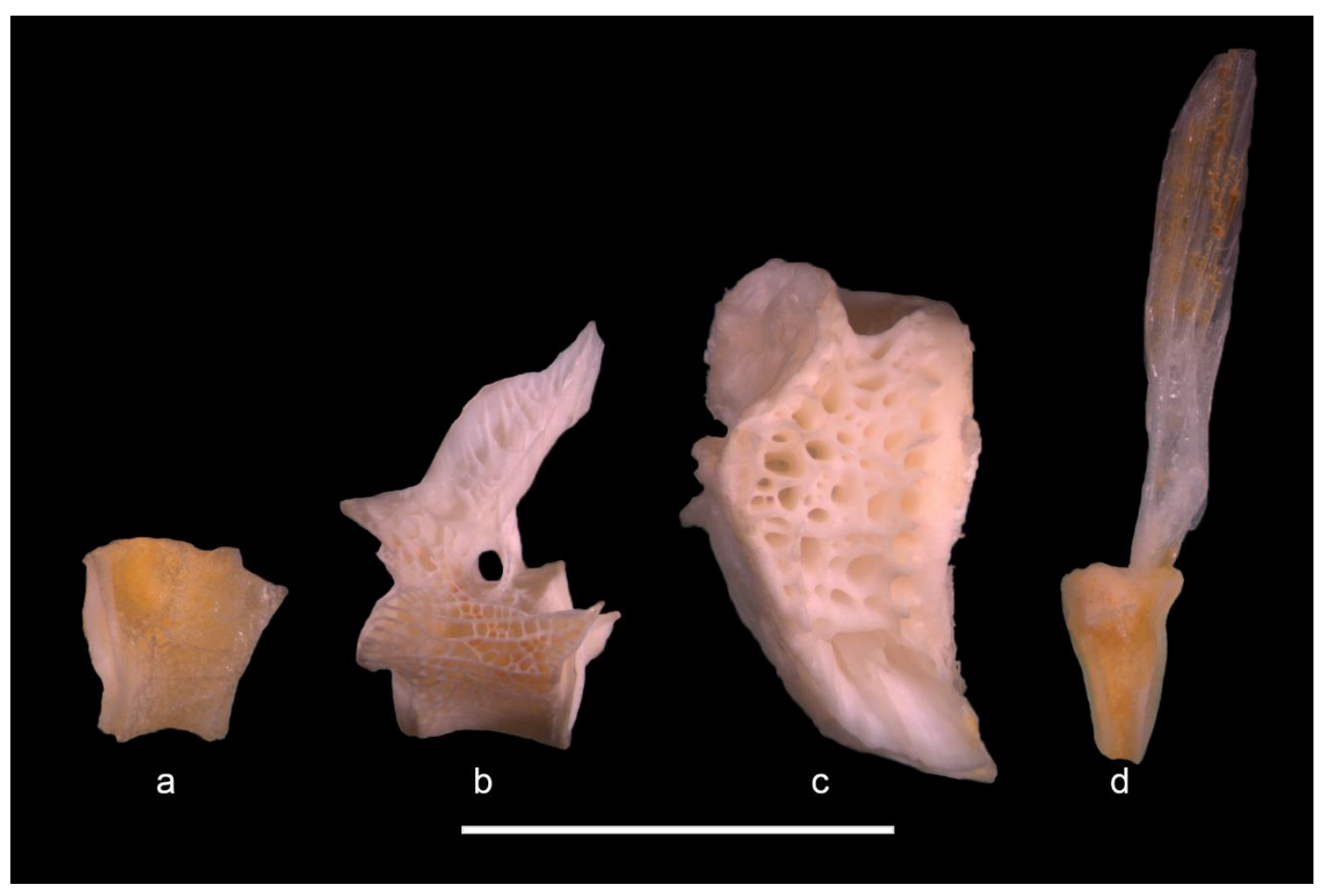

Figure C. 3 - Lateral side of first vertebrae from a) sablefish, b) staghorn sculpin, c) salmon, and e) rex sole. Scale bar is $10 \mathrm{~mm}$ long.

Pleuronectiformes first vertebrae have ovoid exoccipital facets on the dorsolateral sides of an egg-shaped centrum (Figure C.2d).

\section{$\underline{\text { Abdominal Vertebrae }}$}

Abdominal vertebrae are the vertebrae following the first vertebra that do not have a haemal arch or transverse processes. The division between pre-caudal and abdominal vertebrae is not fixed because abdominal vertebrae may have morphological landmarks on the lateral sides that resemble transverse processes. In successive vertebrae, these landmarks do become more prominent until they develop into transverse processes, but the definition of transverse process could be applied arbitrarily to nearly any vertebra in the sequence. For this reason, I do not attempt to distinguish any vertebrae as 
abdominal or pre-caudal. I merely wish to acknowledge that abdominal and pre-caudal vertebrae have different morphology, and describe the differences in both types of vertebra for each taxonomic group.

Sablefish abdominal vertebrae have a very circular centrum face on an ovoid body, and the neural arch attaches to the lateral sides of the centrum body when viewed from the rostral (Figure C.4a) or caudal end. The sablefish abdominal centrum has nearly equal length (rostral-caudal) and height (dorsal-ventral) (Figure C.5a) and never has a foramen on the ventral or lateral sides.

Sculpin abdominal vertebrae have large, robust pre- and postzygapophyses. The centrum body is also noticeably longer (rostral-caudal) than it is tall (dorsal-ventral) (Figure C.4b).

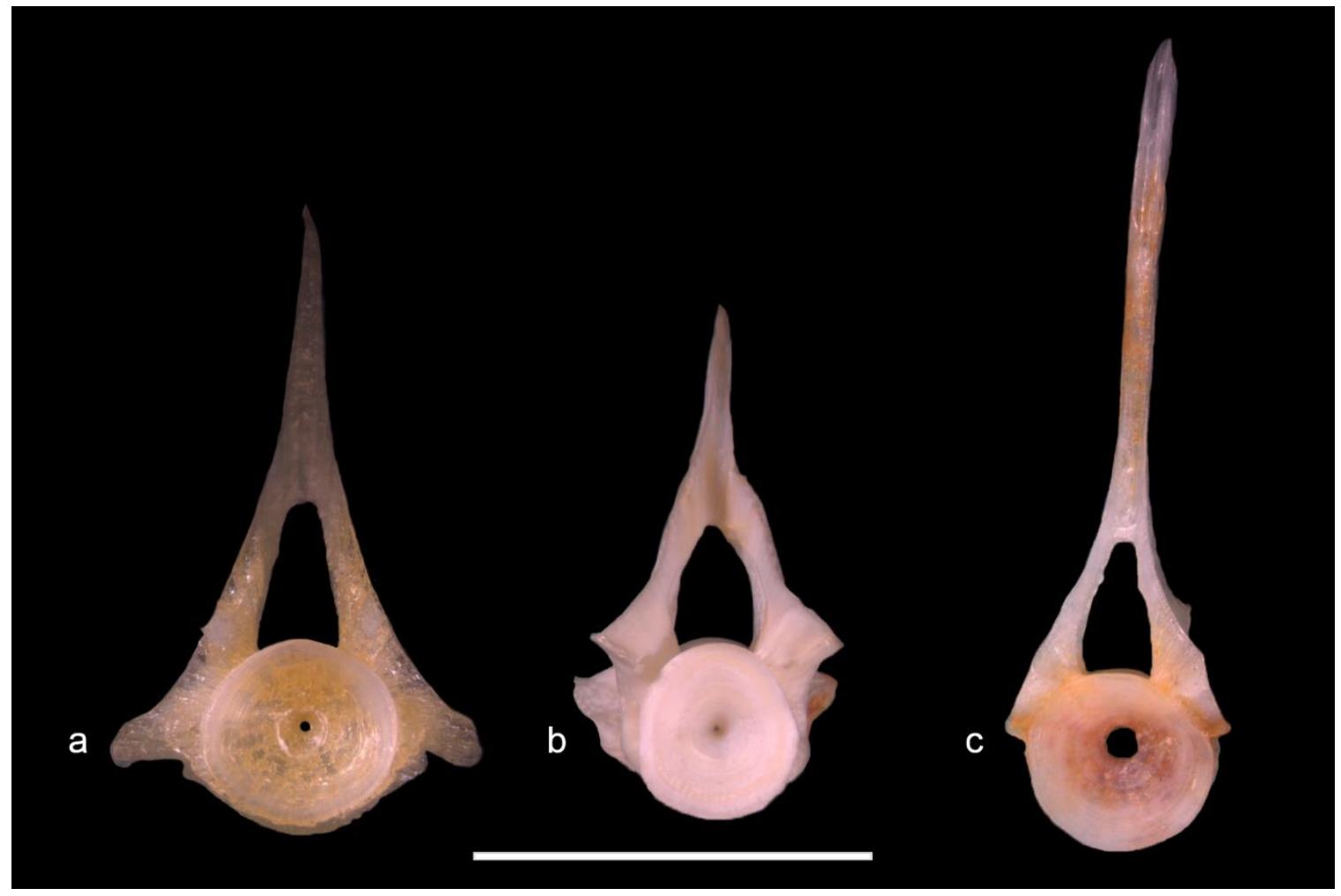

Figure C.4 - Rostral side of abdominal vertebrae from a) sablefish, b) staghorn sculpin, and c) rex sole. Scale bar is $10 \mathrm{~mm}$ long. 


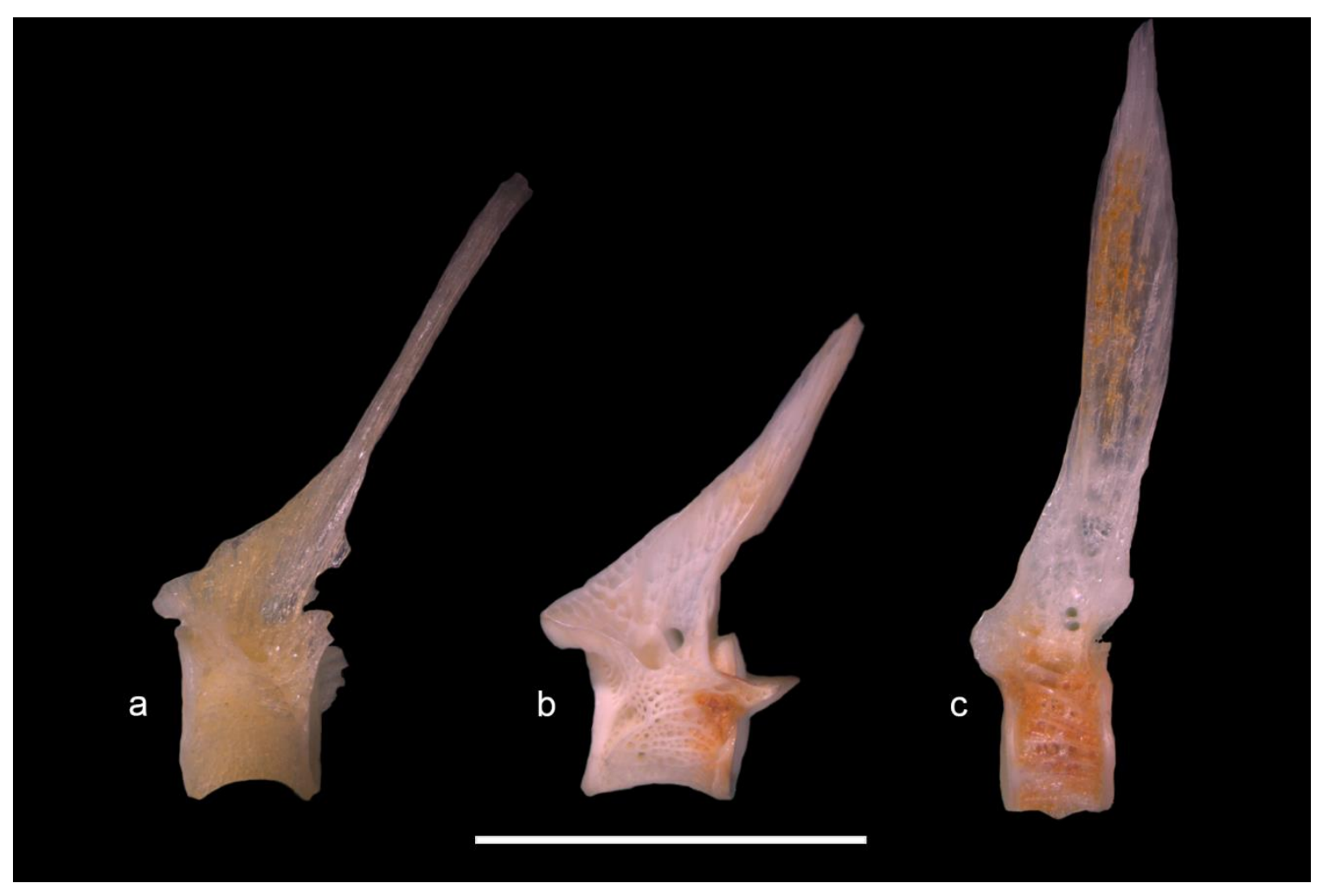

Figure C.5 - Lateral side of abdominal vertebrae from a) sablefish, b) staghorn sculpin, and c) rex sole. Scale bar is $10 \mathrm{~mm}$ long.

The neural arch of the flatfish vertebra connects along the entire length of the centrum's dorsal side (Figure C.5c). The arch also connects closer to the midline on the dorsal side of the centrum (Figure C.4c), rather than to the lateral sides as in sablefish.

\section{$\underline{\text { Pre-caudal Vertebrae }}$}

Sablefish pre-caudal vertebrae have very a circular centrum (Figure C.6a) with transverse processes that connect to the very rostral end of the centrum body (Figure C.7a).

Sculpin pre-caudal vertebrae typically have short transverse processes with facets on the rostral side of the distal end (Figure C.6b). 


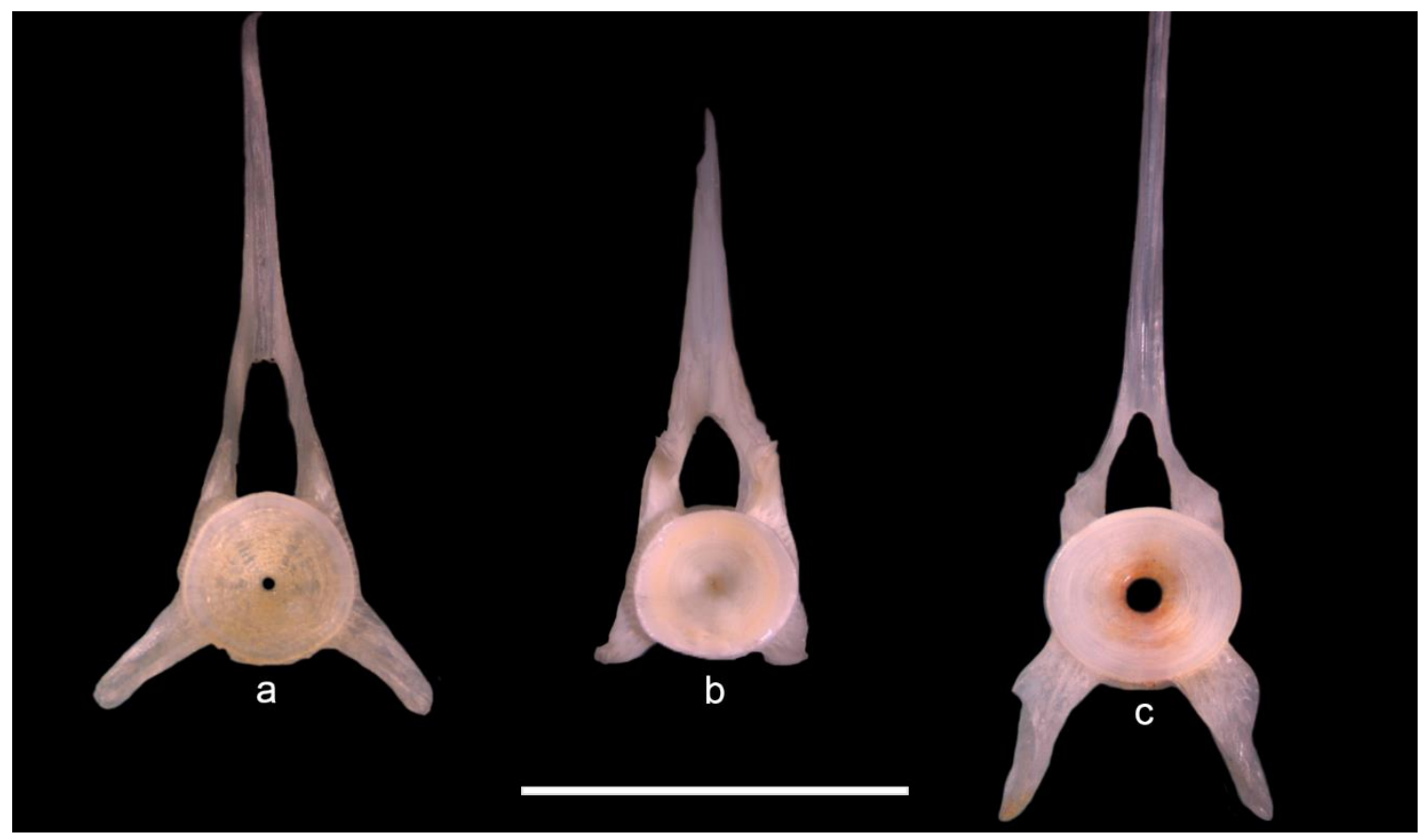

Figure C.6 - Rostral side of pre-caudal vertebrae from a) sablefish, b) staghorn sculpin, and c) rex sole. Scale bar is $10 \mathrm{~mm}$ long.

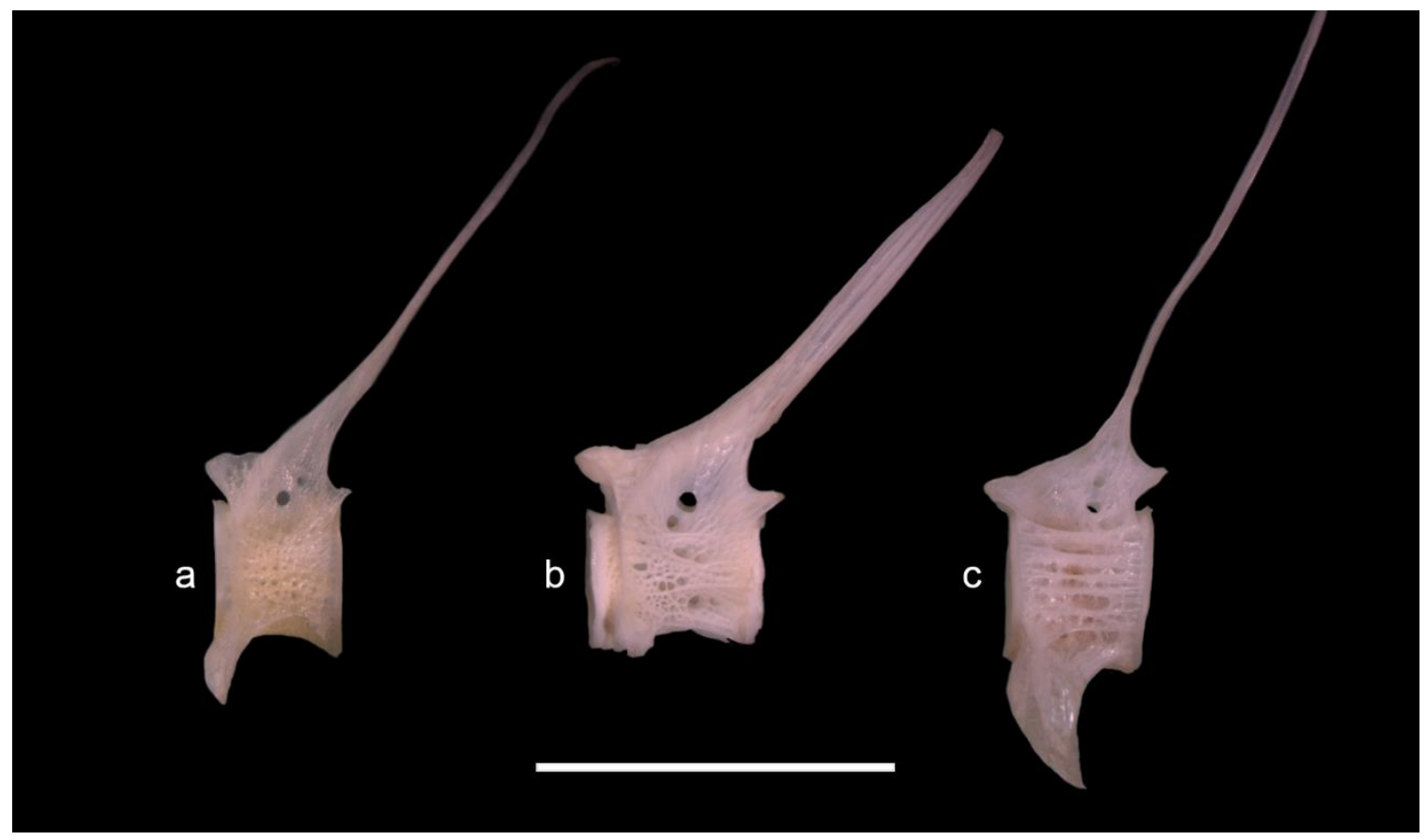

Figure C.7 - Lateral side of pre-caudal vertebrae: a) sablefish, b) staghorn sculpin, and c) rex sole. Scale bar is $10 \mathrm{~mm}$ long. 
Flatfish pre-caudal vertebrae have transverse processes that connect along nearly the entire rostral-caudal length of the centrum body (Figure C.7c).

\section{Caudal Vertebrae}

Caudal vertebrae have a complete haemal arch on the ventral side of the centrum that is formed by the fused ends of the transverse processes.

Sablefish caudal vertebra have a very circular centrum (Figure C.8a) that has nearly equal length (rostral-caudal) and height (dorsal-ventral) (Figure C.9a). The neural arch connects along the entire length of the centrum's dorsal side, but the haemal arch only connects to the very rostral end of the centrum (Figure C.9a).

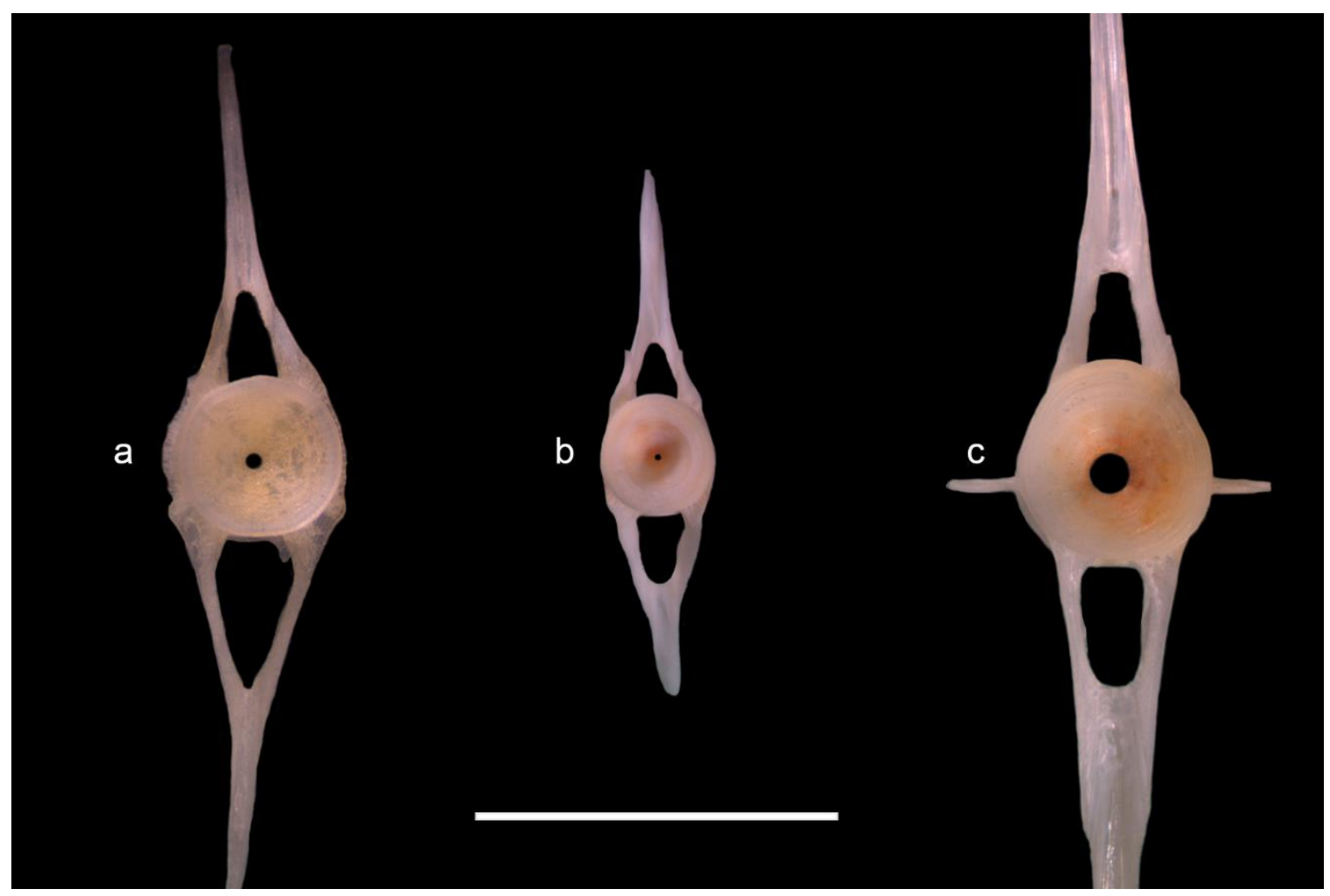

Figure C.8 - Rostral side of caudal vertebrae from a) sablefish, b) staghorn sculpin, and c) rex sole. Scale bar is $10 \mathrm{~mm}$ long. 


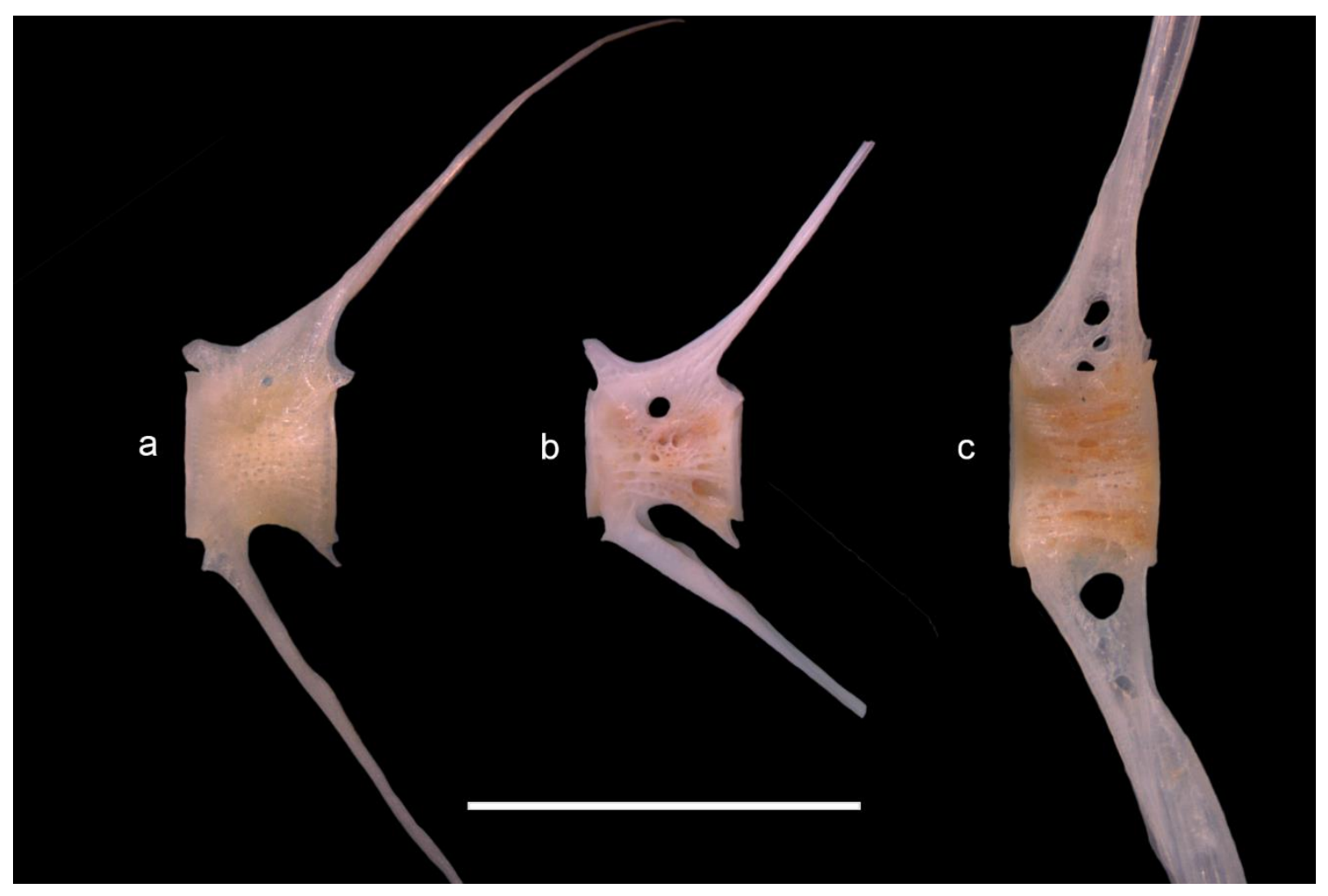

Figure C.9 - Lateral side of caudal vertebrae from a) sablefish, b) staghorn sculpin, and c) rex sole. Scale bar is $10 \mathrm{~mm}$ long.

Sculpin caudal vertebrae have a centrum that is very long (rostral-caudal) relative to its height (dorsal-ventral). The haemal arch also makes a very shallow angle between its caudal end and the centrum body (Figure C.9b).

Flatfish caudal vertebrae have neural and haemal arches that connect along the entire length of the centrum body (Figure C.9c). They also often have barb-like lateral processes (Figure C.8c).

\section{$\underline{\text { Salmonid Vertebra Type } 2}$}

Type 2 salmonid vertebrae have paired facets for the articulation of vertebral spines on the dorsal and ventral sides of the centrum body (Figure C.10a). 


\section{$\underline{\text { Salmonid Vertebra Type } 3}$}

Type 3 salmonid vertebrae have at least one pair of vertebral spines fused to the centrum body (Figure C.10b).

\section{$\underline{\text { Salmonid Vertebra Type } 4}$}

Type 4 salmonid vertebrae have at least one side of the centrum that does not have fused vertebral spines, and the paired facets for the vertebral spines have merged into a single facet (Figure C.10c).

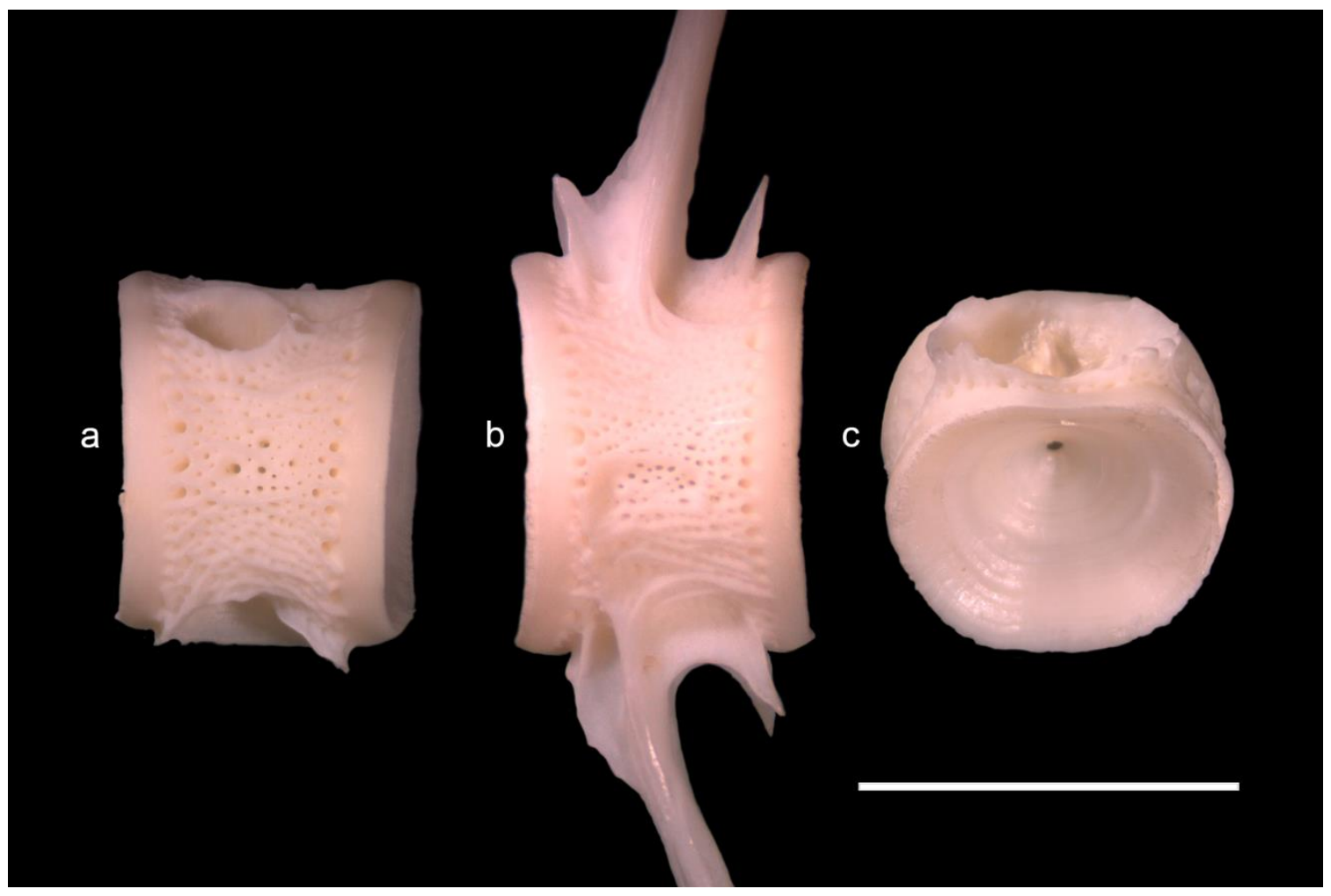

Figure C.10 - Salmon vertebrae a) type 2 - lateral side, b) type 3 - lateral side, and c) type 4 rostral side. Scale bar is $10 \mathrm{~mm}$ long. 


\section{$\underline{\text { Too Caudal }}$}

Towards the extreme caudal end of the non-salmonid vertebral column, caudal vertebrae become smaller, less distinctive, and the angles between the haemal arch and the centrum body, and the neural arch and the centrum body decrease. Many taxa also exhibit lateral barbs on the rostral end of the centrum body. Because these changes cause the extreme caudal vertebrae of all taxa to become more uniform, I do not identify vertebrae that appear to be too caudal.

For sablefish, I define vertebrae as being too caudal to identify if the connection for the haemal arch extends along the entire length of the centrum body (Figure C.11a). The four sablefish in the Portland State University (PSU) Anthropology Department comparative collection have between 4 and 8 vertebrae that meet these criteria.

I define sculpin vertebrae as too caudal if they have barb-like lateral processes that resemble the barb-like processes on flatfish caudal vertebrae, or if the angle between the vertebral spines and the centrum is less than $30^{\circ}$ (Figure C.11b). In 12 sculpin skeletons from the PSU comparative collection, there are between 3 and 7 vertebrae that meet these criteria.

Flatfish caudal vertebrae can be distinguished from the extremely caudal vertebrae of sculpins because the haemal and neural spines of flatfish caudal vertebrae are typically perpendicular to the rostral-caudal axis of the centrum. When the angle between the caudal end of either spine and the centrum body is approximately $60^{\circ}, \mathrm{I}$ consider flatfish vertebrae to be too caudal to identify (Figure C.11c). 


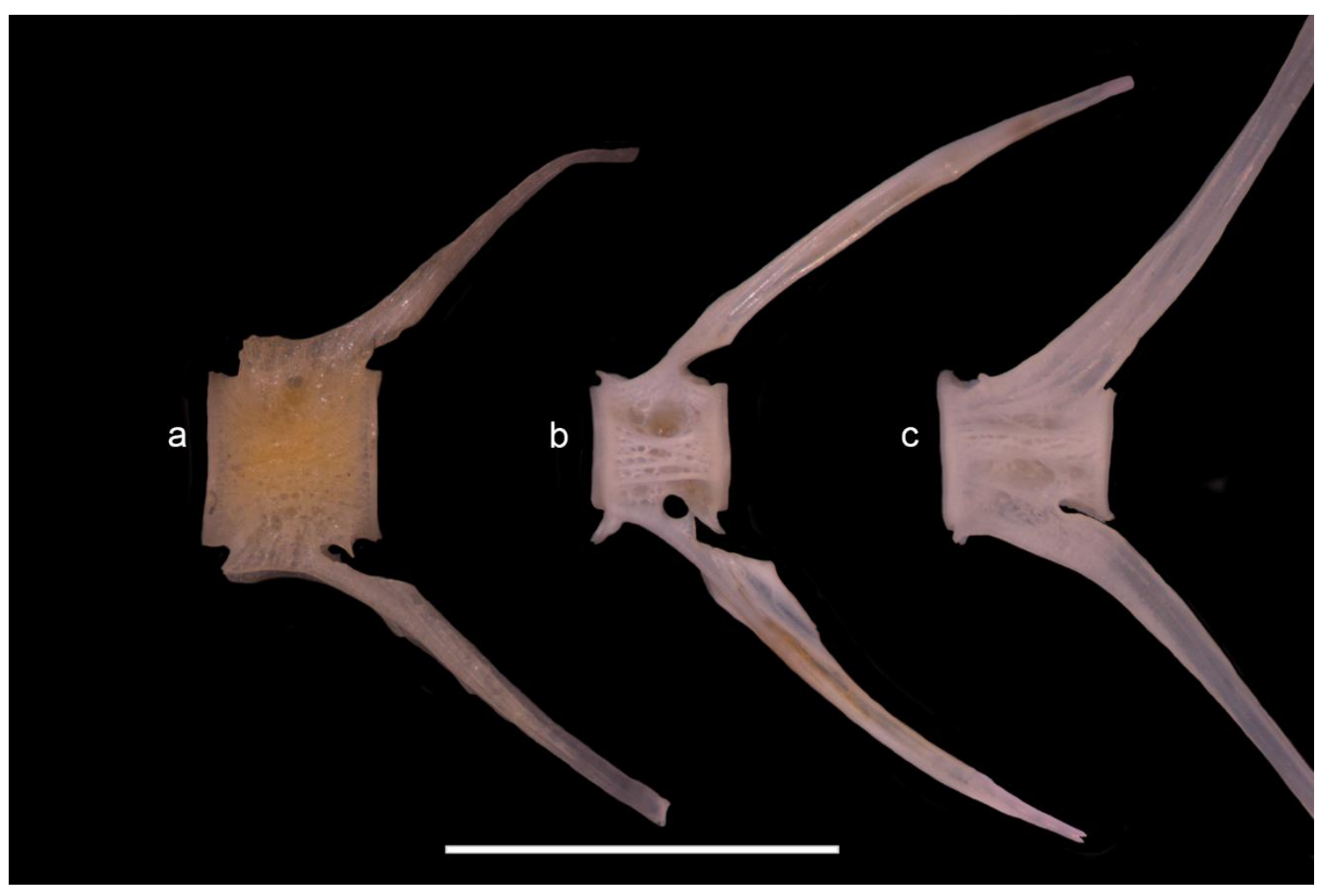

Figure C.11 - Examples of vertebrae too caudal to identify to family in archaeological assemblages from modern a) sablefish, b) staghorn sculpin, and c) rex sole. Scale bar is $10 \mathrm{~mm}$ long. 
Appendix D: C Bags Selected for Reanalysis from Tse-whit-zen 
Table D.1 - Bags selected for reanalysis from Tse-whit-zen.

\begin{tabular}{|c|c|c|c|}
\hline $\begin{array}{c}\text { Analytic } \\
\text { Stage }\end{array}$ & Area & Unit & Catalog Number \\
\hline \multirow[t]{4}{*}{1} & A4 & 17 & $\begin{array}{l}\text { WS-10039.99.02.23 } \\
\text { WS-10039.99.04.23 } \\
\text { WS-10039.99.08.23 }\end{array}$ \\
\hline & A4 & 18 & $\begin{array}{l}\text { WS-10994.99.04.23 } \\
\text { WS-10994.99.08.23 }\end{array}$ \\
\hline & A4 & 19 & $\begin{array}{l}\text { WS-13621.99.04.23 } \\
\text { WS-13621.99.08.23 }\end{array}$ \\
\hline & A4 & 20 & $\begin{array}{l}\text { WS-18082.99.04.23 } \\
\text { WS-18082.99.08.23 }\end{array}$ \\
\hline \multirow[t]{3}{*}{2} & A4 & 14 & $\begin{array}{l}\text { WS-8034.99.04.23 } \\
\text { WS-8034.99.08.23 }\end{array}$ \\
\hline & A4 & 16 & $\begin{array}{l}\text { WS-9146.99.02.23 } \\
\text { WS-9146.99.04.23 } \\
\text { WS-9146.99.08.23 } \\
\text { WS-9475.99.04.23 } \\
\text { WS-9475.99.08.23 }\end{array}$ \\
\hline & A4 & 21 & $\begin{array}{l}\text { WS-10468.99.04.23 } \\
\text { WS-10468.99.08.23 } \\
\text { WS-8097.99.04.23 } \\
\text { WS-8097.99.08.23 }\end{array}$ \\
\hline \multirow[t]{3}{*}{3} & A1 & 4 & $\begin{array}{l}\text { WS-6903.99.04.23 } \\
\text { WS-6903.99.08.23 } \\
\text { WS-691.99.04.23 } \\
\text { WS-691.99.08.23 }\end{array}$ \\
\hline & A1 & 5 & $\begin{array}{l}\text { WS-549.99.04.23 } \\
\text { WS-549.99.08.23 } \\
\text { WS-7897.99.04.23 } \\
\text { WS-7897.99.08.23 }\end{array}$ \\
\hline & A1 & 8 & WS-189.99.08.23 \\
\hline
\end{tabular}


Appendix E: Supplemental Data File - Primary fish bone data for the original analysis and reanalysis of a portion of the Tse-whit-zen assemblage

Name: Supplementary Appendix E - Tse-whit-zen Reanalysis.xlsx

Description: This spreadsheet includes original analysis and reanalysis results for buckets listed in Appendix A. The column heading "Stage" refers to Analytic Stage in Appendix A, and the column heading "Analysis" refers to whether a given entry was identified in the original analysis (A) or the reanalysis (B). Entries for the reanalysis also include original taxonomic identifications for a specimen where the results of the analysis and the reanalysis differ.

File Type: Microsoft Excel Spreadsheet

File Size: $132 \mathrm{~kb}$

Required Software: Microsoft Excel 2007 (or newer) 
Appendix F: Supplemental Data File - Primary fish bone data from the reanalysis of portions of Burton Acres (45KI437), Decatur Island (45IS169), English Camp (45SJ24 Op A and Op D), and West Point (45KI428 and 45KI429)

Name: Supplementary Appendix F - Sablefish Verification.xlsx

Description: This spreadsheet includes vertebra counts for sablefish (Anoplopoma fimbria), salmon (family Salmonidae), sculpins (family Cottidae), and flatfish (order Pleuronectiformes) specimens that I identified from each bucket listed in Appendix C using criteria reported in Appendix D. Each entry also includes the identification made by the original analyst.

File Type: Microsoft Excel Spreadsheet

File Size: $34.1 \mathrm{~kb}$

Required Software: Microsoft Excel 2007 (or newer) 